\title{
Effects of Selective Forest Clearing, Fertilization, and Liming on the Hydrology and Water Quality of a Small Tributary to the Quabbin Reservoir, Central Massachusetts
}

U.S. Geological Survey

Water-Resources Investigations Report 95-4124

Prepared in cooperation with the

COMMONWEALTH OF MASSACHUSETTS

METROPOLITAN DISTRICT COMMISSION

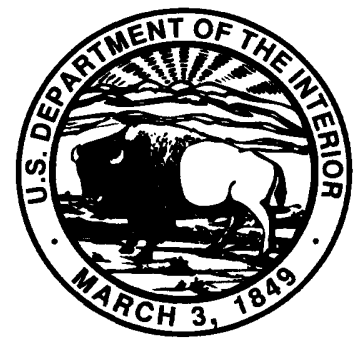


Effects of Selective Forest Clearing, Fertilization, and Liming on the Hydrology and Water Quality of a Small Tributary to the Quabbin Reservoir, Central Massachusetts

By JAMES B. SHANLEY, JEFFREY L. STRAUSE, and JOHN C. RISLEY

U.S. Geological Survey

Water-Resources Investigations Report 95-4124

Prepared in cooperation with the COMMONWEALTH OF MASSACHUSETTS METROPOLITAN DISTRICT COMMISSION

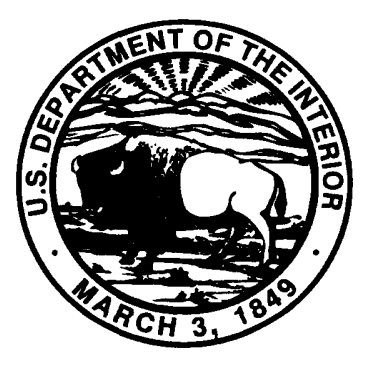

Marlborough, Massachusetts 1995 


\title{
U.S. DEPARTMENT OF THE INTERIOR BRUCE BABBIT, Secretary
}

\author{
U.S. GEOLOGICAL SURVEY \\ Gordon P. Eaton, Director
}

For additional information write to:

Chief, Massachusetts-Rhode Island District U.S. Geological Survey Water Resources Division 28 Lord Road, Suite 280 Marlborough, MA 01752
Copies of this report can be purchased from:

\author{
U.S. Geological Survey \\ Earth Science Information Center \\ Open-File Reports Section \\ Box 25286, MS 517 \\ Denver Federal Center \\ Denver, CO 80225
}




\section{CONTENTS}

Abstract Introduction

Purpose and Scope

Previous Studies.

Experimental Design

Description of Study Area

Acknowledgments

Methods of Study

Hydrologic Data Collection

Water-Quality Data Collection

Hydrologic Data Analysis

Calculations of Flow

Construction of Flow-Duration Curves..

Calculations of Evapotranspiration .

Water-Quality Data Analysis

Solute-Concentrations Models

Calculation of Solute Loads

Pre-Treatment Hydrologic Characteristics of Experimental and Control Basins

Precipitation

Surface-Water Flow

Ground-Water Levels.

Pre-Treatment Water-Quality Characteristics of Experimental and Control Basins.

Precipitation.

Surface Water.

Ground Water.

Effects of Selective Forest Clearing on Hydrology...

Changes in Surface-Water Flow

Changes in Ground-Water Levels

Changes in Evapotranspiration

Effects of Selective Forest Clearing, Fertilization, and Liming on Water Quality

Changes in Solute Fluxes

Changes in Sediment Transport.

Changes in Biogeochemical Controls on Water Quality

Changes in Acid-Neutralization Processes.

Summary and Conclusions.

\section{FIGURES}

1-3. Maps showing:

1. Location of the study areas and data-collection sites near Quabbin Reservoir, central Massachusetts.

2. Geology of the control and experimental basins near Quabbin Reservoir, central Massachusetts.

3. Areas of forest clearing, fertilization, and liming in the experimental basin near Quabbin Reservoir, central Massachusetts. 
4-7. Graphs showing:

4. Precipitation in the control and experimental basins, Dickey Brook Basin near Quabbin

Reservoir, central Massachusetts, water years 1985-89

5. Streamflow and base flow in the experimental and control basins near Quabbin Reservoir, central Massachusetts, during the pre-treatment period, February 1985 through October 1986

6. Flow-duration curves for the experimental and control basins, near Quabbin Reservoir, central Massachusetts, during the pre-treatment period, February 1985 through October 1986

7. Ground-water levels in two wells in the experimental and control basins, near Quabbin Reservoir, central Massachusetts, during the pre-treatment period, February 1985 through October 1986

8. Boxplots of $\mathrm{pH}$, alkalinity, and solute concentrations at New Salem, the control basin, and the experimental basin, near Quabbin Reservoir, central Massachusetts during the pre-treatment period, February 1985 through October 1986

9. Diagram showing percentage of chemical constituents in streamwater from the control and experimental basins, Dickey Brook Basin, central Massachusetts, during the pre-treatment period, February 1985 through October 1986

10. Triliner diagram showing percentage of chemical constituents in ground water from the control and experimental basins, Dickey Brook Basin, central Massachusetts, during the pre-treatment period, February 1985 through October 1986

11,12. Graphs showing

11. Timing of treatments and annual precipitation and annual runoff at the control and experimental basins, Dickey Brook Basin, central Massachusetts, water years 1985 through 1989

12. Timing of treatments and monthly runoff from control and experimental basins, Dickey Brook Basin, central Massachusetts, February 1985 through September 1989

13. Flow-duration curves for the control and experimental basins, Dickey Brook Basin, central Massachusetts, during the post-treatment period, November 1986 through September 1989

14. Scatterplots and regression models of daily mean streamflow data from the pre- and post-treatment periods at the control and experimental basins, Dickey Brook Basin, central Massachusetts

15. Flow-duration curves for the experimental basin, Dickey Brook Basin, central Massachusetts, during the post-treatment period, computed from measured and simulated daily mean streamflow

16-21. Graph showing:

16. Ground-water levels in wells in the control and experimental basins, Dickey Brook

Basin, central Massachusetts, February 1985 through September 1989

17. Estimated monthly potential evapotranspiration for the study area, Dickey Brook Basin, central Massachusetts

18. Solute concentrations in stream water at the control- and experimental-basin outlets, Dickey Brook Basin, central Massachusetts, February 1985 through September 1989

19. Annual input and output fluxes at the control and experimental basin outlets, Dickey Brook Basin, central Massachusetts, water years 1985 through 1989

20. Timing of treatments in experimental basin and monthly solute fluxes in streamwater at the control- and experimental-basin outlets, Dickey Brook Basin, central Massachusetts, February 1985 through September 1989

21. Timing of treatments and concentrations of suspended sediment at the control-basin outlet, experimental-basin headwaters gage, and experimental-basin outlet, Dickey Brook Basin, central Massachusetts, February 1985 through September 1989 


\section{TABLES}

1. Summary of forest clearing, fertilization, and liming treatments in the experimental basin, Dickey

Brook Basin, central Massachusetts

2. Chemical constituents analyzed for the study, near Quabbin Reservoir, central Massachusetts ......

3. Results of pre- and post-treatment regression analysis and analysis of covariance on daily flows at the control and experimental basins near Quabbin Reservoir, central Massachusetts

4. Estimated annual decrease in evapotranspiration as a result of selective forest clearing in the experimental basin, Dickey Brook Basin, central Massachusetts

5. Fertilizer and lime inputs to experimental basin, normalized to basin area, Dickey Brook Basin, central Massachusetts

6. Parameters and coefficients of models used to estimate solute fluxes near Quabbin Reservoir, central Massachusetts

7. Ratios of runoff-normalized annual solute fluxes in the experimental basin to runoff-normalized annual solute fluxes in the control basin, Dickey Brook Basin, central Massachusetts

\section{CONVERSION FACTORS, VERTICAL DATUM, AND ABBREVIATED WATER-QUALITY UNITS}

\begin{tabular}{|c|c|c|}
\hline Multiply & By & To obtain \\
\hline centimeter $(\mathrm{cm})$ & 0.3937 & inch \\
\hline cubic meter per second $\left(\mathrm{m}^{3} / \mathrm{s}\right)$ & 35.31 & cubic foot per second \\
\hline hectare (ha) & 2.471 & acre \\
\hline kilogram (kg) & 2.205 & pound \\
\hline kilometer (km) & 0.6214 & mile \\
\hline liter per second $(\mathrm{L} / \mathrm{s})$ & 0.1585 & cubic foot per second \\
\hline metric ton $(t)$ & 0.386 & British ton \\
\hline meter $(\mathrm{m})$ & 0.30481 & foot \\
\hline millimeter $(\mathrm{mm})$ & 0.03937 & inch \\
\hline square kilometer $\left(\mathrm{km}^{2}\right)$ & 0.3861 & square mile \\
\hline \multicolumn{3}{|c|}{ The following abbreviations are used in the report: microequivalent per liter $(\mu \mathrm{eq} / \mathrm{L})$ and micromohls per liter $(\mu \mathrm{mhos} / \mathrm{L})$. } \\
\hline \multicolumn{3}{|c|}{ Temperature in degrees Celsius $\left({ }^{\circ} \mathrm{C}\right)$ can be converted to degrees Fahrenheit $\left({ }^{\circ} \mathrm{F}\right)$} \\
\hline \multicolumn{3}{|c|}{ by use of the following equation: } \\
\hline \multicolumn{3}{|c|}{${ }^{\circ} \mathrm{F}=1.8\left({ }^{\circ} \mathrm{C}\right)+32$} \\
\hline
\end{tabular}

Sea level: In this report, "sea level" refers to the National Geodetic Vertical Datum of 1929 (NGVD of 1929)-a geodetic datum derived from a general adjustment of the first-order level nets of both the United States and Canada, formerly called "Sea Level Datum of 1929."

\section{ABBREVIATED WATER-QUALITY UNITS}

Chemical concentrations and water temperature are given in metric units. Chemical concentration is given in milligrams per liter ( $\mathrm{mg} / \mathrm{L}$ ). Milligrams per liter is a unit expressing the concentration of chemical constituents in solution as weight (milligrams) of solute units of solute unit per unit volume (liter) of water. One thousand micrograms per liter is equivalent to one milligram per liter. 


\title{
EFFECTS OF SELECTIVE FOREST CLEARING, FERTILIZATION, AND LIMING ON THE HYDROLOGY AND WATER QUALITY OF A SMALL TRIBUTARY TO THE QUABBIN RESERVOIR, CENTRAL MASSACHUSETTS
}

\author{
By James B. Shanley, Jeffrey L. Strause, and John C. Risley
}

\section{Abstract}

Effects of selective forest clearing on water yield and water quality were investigated in a 308hectare basin that drains to Quabbin Reservoir Watershed in central Massachusetts. The experimental basin and a nearby 280 -hectare control basin were studied together for comparison. Streamflow was measured continuously and water-quality samples were collected biweekly in both basins from February 1985 through September 1989. During the same period, measurements of precipitation quantity and ground-water levels were made and samples were collected for determination of precipitation and ground-water quality.

After an initial monitoring period to establish baseline hydrology and water quality in both basins, an area of red pine and white pine forest in the experimental basin was cleared. From October 1986 until April 1987, 23.8 percent of the total basal area was removed by clearcutting and thinning. Part of the cleared area was converted to rye and other field grasses, and the remainder was allowed to regrow naturally. Fertilizer and lime were applied to part of the cleared area. An additional 8.3 percent of basal area was cleared in autumn 1988.

Despite differences in bedrock geology, topography, and amount of wetland area, pre-treatment hydrology and chemistry of the two basins were similar. Biogeochemical reactions of the dilute mixture of sulfuric and nitric acids in precipitation with soils and rocks in the basins resulted in moderately buffered calcium magnesium bicarbonate type streamwater. During high flows, sulfate concentrations increased and alkalinity decreased. Selective forest clearing resulted in a slight increase in water yield during the year in which the clearing took place, particularly during the spring high-flow period, but flows returned to normal thereafter. Concurrent increases in solute flux were primarily a function of the increased water flux. No major alterations to biogeochemical processes were induced by the forest clearing, nor were any effects from the fertilizer or liming activity observed. The minimal effect observed from the clearing was attributed primarily to the limited area that was cleared, and the location of the cleared area in the headwaters of the basin (away from the riparian zone).

\section{INTRODUCTION}

Quabbin Reservoir in central Massachusetts (fig. 1) is the principal source of water supply for the metropolitan Boston area. During the early 1980's, the average daily demand on the system exceeded the design capacity of the reservoir. Although system improvements and a recent conservation program have significantly reduced daily demand, the agencies responsible for municipal water supply and delivery, the Metropolitan District Commission (MDC) and the Massachusetts Water Resources Authority (MWRA), continue to seek viable ways to increase the water supply. The Division of Watershed Management of the MDC is required by State law to periodically prepare watershed management plans that provide for water yield enhancement. 


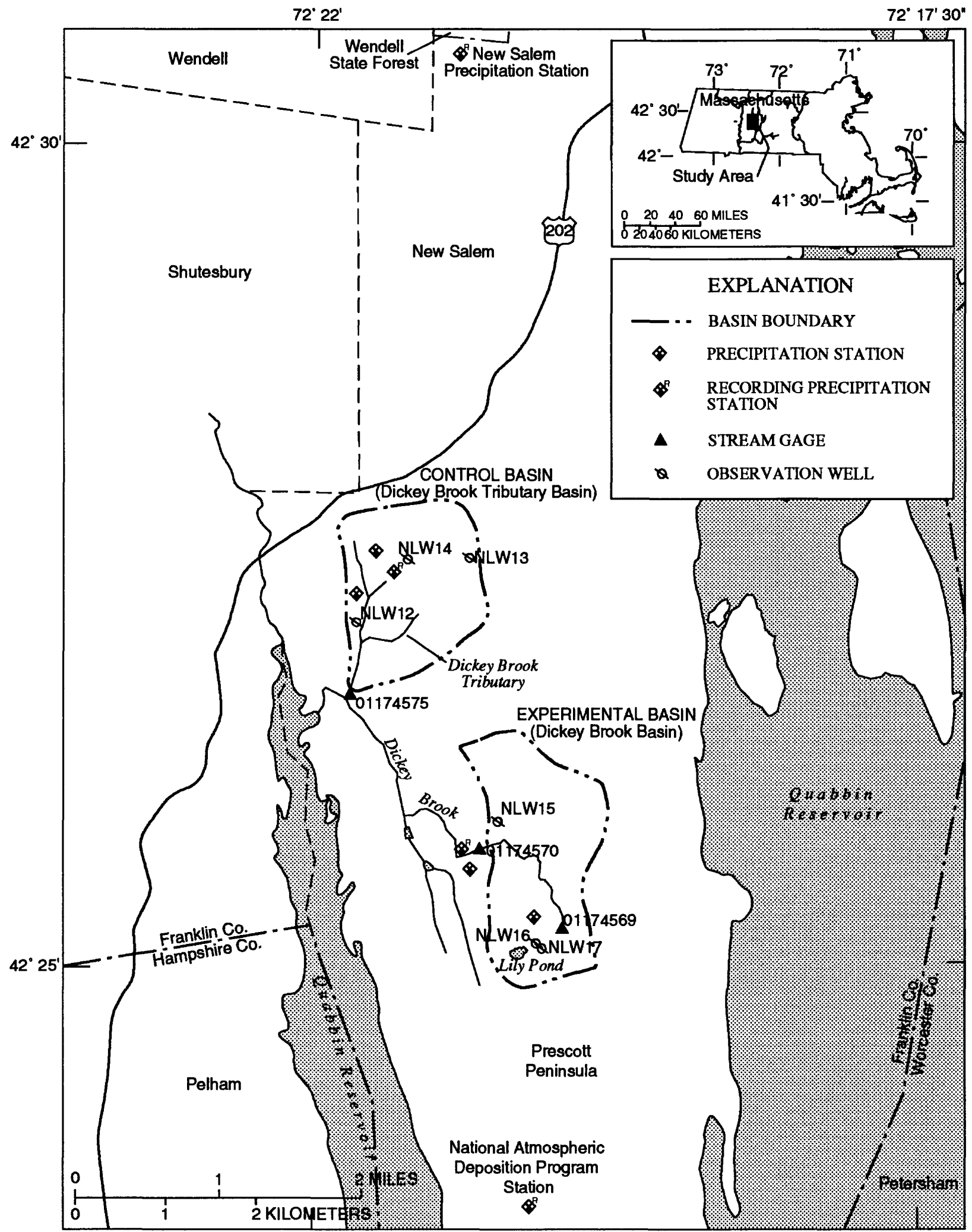

Base from U.S. Geological Survey

Quabbin Reservoir, 1967 Photorevised, 1979

Figure 1. Location of the study areas and data-collection sites near Quabbin Reservoir, central Massachusetts. 
In addition to maintaining an adequate water supply, the MDC is equally concerned about maintaining water quality that is suitable for drinking and other municipal uses. Most of the land within the $482-\mathrm{km}^{2}$ Quabbin Reservoir drainage basin is managed as a protected area by the MDC; however, water quality may still be adversely affected by deicing-salt runoff (Shanley, 1994) and acid precipitation (Godfrey, 1988; Yuretich and others, 1989). The MDC is concerned that acidic precipitation may adversely affect aquatic life and upset the ecological balance in streams tributary to the reservoir and in the reservoir. Also, acidified water could increase the leaching of lead from service lines and plumbing, potentially causing tap water to have concentrations of lead that exceed drinking water standards. Weathering reactions with aquifer materials in the Quabbin watershed neutralize acid inputs, but the acid-neutralizing capacity of the reservoir is low compared to most bodies of water for its size. Forest clearing is another activity that may acidify surface waters (Lawrence and others, 1987); thus, cutting of trees also is of concern because of its potential effects on water quality.

In October 1984, the U.S. Geological Survey (USGS), in cooperation with the Watershed Management Division of the MDC, began the first of two phases of a $4 \frac{1}{2}$-year study to evaluate the effects of selective forest clearing on the quality of ground water and surface water in a tributary to the Quabbin Reservoir. In the first phase, water quality and hydrologic characteristics of two basins of the tributary were assessed before forest clearing. In the second phase, stands of red and white pine were selectively cleared in the experimental basin, and the cleared land was partially converted to limed, fertilized fields of grass. Water quality continued to be monitored in the experimental basin and the control basin during the post-treatment period, allowing an assessment of the effects of forest clearing and land conversion on water yield and water quality.

\section{Purpose and Scope}

This purpose of this report is twofold: (1) to present the effects of selective forest clearing on the hydrology of the basins, and (2) to present the effects of selective forest clearing on water quality.

This report summarizes hydrologic and waterquality data collected in Dickey Brook Basin and Dickey Brook Tributary Basin from October 1984 through September 1989. Collection of water-quality and hydrologic data in the control basin and the experimental basin began with instrumentation and some preliminary measurements in late 1984 . Full data collection for the pre-treatment phase began in February 1985. Selective forest clearing of red and white pine stands began in October 1986 and continued throughout the following winter. Data collection continued through September 1989.

\section{Previous Studies}

Results of previous studies of the effect of forest clearing on water yield generally have shown that water yield increases in proportion to the amount of forest cleared (Hornbeck and others, 1993). Likens and others (1970), Mrazik and others (1980), and Hornbeck and others (1993) have shown that runoff increases substantially in a watershed after forest clearing takes place. Verry (1986) points out, however, that forestclearing experiments have shown little effect on water yields in forests with high water tables, which are common in the Quabbin area.

At a 34-ha watershed in West Virginia, Aubertin and Patric (1974) found that runoff increased $200 \mathrm{~mm}$ during the first year after conventional clearcutting. Although most of the watershed was cleared, a small buffer zone of trees was left along the stream channel. Turbidity and nitrate-nitrogen and phosphate concentrations increased slightly during storms, but changes in stream temperature, $\mathrm{pH}$, and turbidity between storms after clearcutting were negligible. Furthermore, little change was observed in concentrations of dissolved solids, calcium, magnesium, sodium, potassium, iron, copper, zinc, manganese, and ammonium.

During 1971-73, streamwater at the outlets of 23 watersheds in the White Mountains of New Hampshire was sampled and analyzed for nitrate and calcium (Martin and Pierce, 1980). Nine watersheds were completely clearcut, seven watersheds were partially clearcut, and nine neighboring watersheds (selected as control watersheds) were undisturbed. Nitrate and calcium concentrations in the clearcut basins increased to maximums of 25.1 and $6.5 \mathrm{mg} / \mathrm{L}$, respectively. Maximum nitrate and calcium concentrations of the undisturbed basins were 4.8 and $3.2 \mathrm{mg} / \mathrm{L}$, respectively, during the period. 
Mrazik and others (1980) studied increases in water yield resulting from selective clearing of mature trees on the 163-ha Cadwell Creek Watershed of the Quabbin Reservoir. Removal of about one-third of the basal area of trees resulted in increases in water yield of 22,22 , and 20 percent in the first 3 years after selective clearing.

Harr (1986) studied the effect of clearcutting on rain-on-snow runoff in western Oregon. He found that clearcutting altered snow accumulation and snowmelt patterns in a way that increased the size of peak streamflows caused by snowmelt during rainfall in a 96-ha and a 10-ha watershed.

The effects of two management practices, progressive strip cutting and block clearcutting, on the hydrology and water quality of small watersheds at the Hubbard Brook Experimental Forest, N.H. were studied by Hornbeck and others (1986). In the block-clearcut watershed, streamflow for the 10 -year period after harvesting was 7 percent greater than it would have been had the trees in the watershed not been harvested. Streamflow during the same 10-year period in the stripcut watershed was 4 percent greater than it would have been had the trees in the watershed not been harvested. Maximum concentrations of calcium, magnesium, potassium, hydrogen, and nitrate collected from the block-clearcut watershed during the 10-year period were consistently higher than maximum concentrations of these constituents found in samples from the strip-cut watershed. Conversely, maximum concentrations of sodium, ammonium, sulfate, and chloride in runoff from the block-clearcut watershed were consistently lower than the maximum concentrations of these constituents in runoff from the strip-cut watershed.

Martin and Harr (1989) investigated the effect of the logging of mature Douglas fir trees in western Oregon on nutrient-output budgets. Three watersheds representing clearcut, partially cut, and undisturbed conditions were studied. Nitrate was the only measured constituent affected by logging. Despite a thirty-fold increase in nitrate export from the clearcut basin, nitrate concentrations were so low that more than twice as much nitrate-nitrogen was added to the clearcut watershed from precipitation as was lost in streamwater.

\section{Experimental Design}

A paired-watershed approach was used in this study to assess the effects of selective clearing on water yield and chemical fluxes from a small forested watershed. Whereas the design of this study is similar to earlier studies, few studies have specifically addressed the hydrologic and biogeochemical effects of long-term conversion to field cover. In the paired-watershed approach, two basins in close proximity were selected as the experimental and control basins. The best possible attempt was made to match basin characteristics, including mean elevation, drainage area, topography, soils, vegetation, and geology. Hydrologic and waterquality data were collected in both basins throughout the study. After $1 \frac{1}{2}$ years of baseline data were collected, red and white pine stands were selectively cleared in the experimental basin, and the cleared area was partially converted to rye and other field grasses. The control basin was left undisturbed.

In this study, both watersheds were monitored for $1 \frac{1}{2}$ years before forest clearing was initiated. During this time, relations in hydrologic and hydrochemical patterns between the basins are established. Effects of forest clearing were deduced from post-treatment changes in the nature of these relations. By comparison of the two basins, long-term trends were determined from seasonal variations.

Given a streamflow relation between the two basins for the pre-treatment period, the streamflows in the experimental basin during the post-treatment period had there been no clearing could be determined. The expected increase in water yield in the experimental basin during the post-treatment period resulting from the cutting can be quantified by subtracting calculated streamflows (calculated from an empirical pretreatment streamflow relation) from observed streamflows (Troendle, 1983; Troendle and King, 1985). Trimble and others (1987) applied an analogous technique to examine the reverse condition, that is, the reduction in water yield from reforestation in the Piedmont of the southern United States.

A similar method-comparison of flow observed with flow predicted from a pre-treatment flow regression - was used in this study. Changes in streamsolute flux caused by the forest clearing were likewise evaluated by examining differences in pre- and posttreatment. Patterns of solute fluxes in the experimental 
basin relative to those in the control basin were compared for the pre-treatment and post-treatment periods. Changes in flux were evaluated with reference to changes in water yield (for example, whether an increase of 10 percent in solute flux could be explained by an increase of 10 percent in water yield), and results were compared to results of other studies.

\section{Description of Study Area}

The study basins are on the Prescott peninsula in the Quabbin Reservoir Watershed in central Massachusetts (fig. 1). Dickey Brook Tributary, the control basin, drains 280 ha; Dickey Brook, the experimental basin, drains 308 ha. Both basins are mostly forested with a mixture of oak, eastern white pine, birch, red maple, hemlock, spruce, and red pine.

Bedrock geology in the study area is characterized by two distinct consolidated units of the Prescott Complex: a hornblende gabbro member, which covers nearly all of the eastern half of the control basin and less than 10 percent of the experimental basin, and the Cooleyville Granitic Gneiss member, which underlies most of the western half of the control basin and nearly all of the experimental basin (fig. 2) (Makower, 1964; Zen and others, 1983). The presence of gabbro causes the $\mathrm{pH}$ of surface water in both basins to remain nearly neutral, in contrast to the more acidic surface water in most basins of similar size in the region (Gallant and others, 1990). Surficial geology includes unconsolidated deposits of mostly fine-grained till and some outwash. The unconsolidated deposits are more prevalent in the experimental basin than in the control basin (David Ashenden, Massachusetts Water Resources Authority, written commun., 1987).

The average topographic gradient between the highest point in the basin and the basin outlet is about 5 percent in the control basin and about 2 percent in the experimental basin. Drilled boreholes in the study area indicate that the till thickness ranges from about 1.5 to $12.0 \mathrm{~m}$. Slopes facing north and west consistently have thicker till deposits than slopes facing south and east. Soils in both basins are fine sandy loam with permeability ranging from 5.1 to $16.0 \mathrm{~cm} / \mathrm{h}$. The available water capacity ranges from about 10 to 20 percent. By area, wetlands comprise about 15 percent of the experimental basin and 4 percent of the control basin.
Wetlands in both basins support beaver colonies, resulting in the loss of tree cover; regrowth has been limited because of deer browsing.

Red pine stands were planted throughout the Quabbin Reservoir Watershed during the construction of the reservoir in the 1930's and 1940's. Red pine was the only tree species that was thinned or clearcut during the study. Because the annual water consumption of pines is higher than the annual water consumption of other tree species, the elimination of pine stands has been considered a viable means of increasing the water yield from basins contributing to the reservoir.

During the main period of forest clearing in the first half of water year $1987^{1}, 21.9$ ha of pine forest was cleared and 9.3 ha was thinned in the experimental basin (fig. 3). The overall reduction of forest basal area (total cross-sectional area of tree stems) was 23.8 percent (table 1). Because pines have a higher stocking density than other trees in the basins, this 23.8-percent reduction in basal area was achieved by clearing only 7.1 percent and thinning 3.0 percent of the basin area. Of the 21.9 ha in the initial clearing, part of the area was harrowed; 2.7 ha was planted to rye grass and 4.1 ha was planted to field mix (table 1) in September 1987. The remaining cleared area was allowed to regrow naturally. The grass area was fertilized in October 1987 and limed in September 1988. From October 24 through December 8,1988 , an additional 8.3 percent of basal area was removed by a clearing of 6.5 ha and thinning of 5.7 ha of pine stands in the northern section of the basin near the outlet.

\section{Acknowledgments}

We wish to thank Karen Eager and Bruce Spencer of the Metropolitan District Commission for supplying data and supplementary information for this study. Gardner C. Bent of the U.S. Geological Survey, Marlborough, Mass., made many helpful suggestions for the hydrologic analyses. Leslie A. DeSimone of the U.S. Geological Survey, Marlborough, Mass., helped extensively with figure drafting and text organization.

\footnotetext{
${ }^{1}$ Water year is the 12-month period, October 1 through September 30 . The water year is designated by the calendar year in which it ends and which includes 9 of the 12 months. Thus, the year ending September 30, 1980, is called "water year 1980."
} 


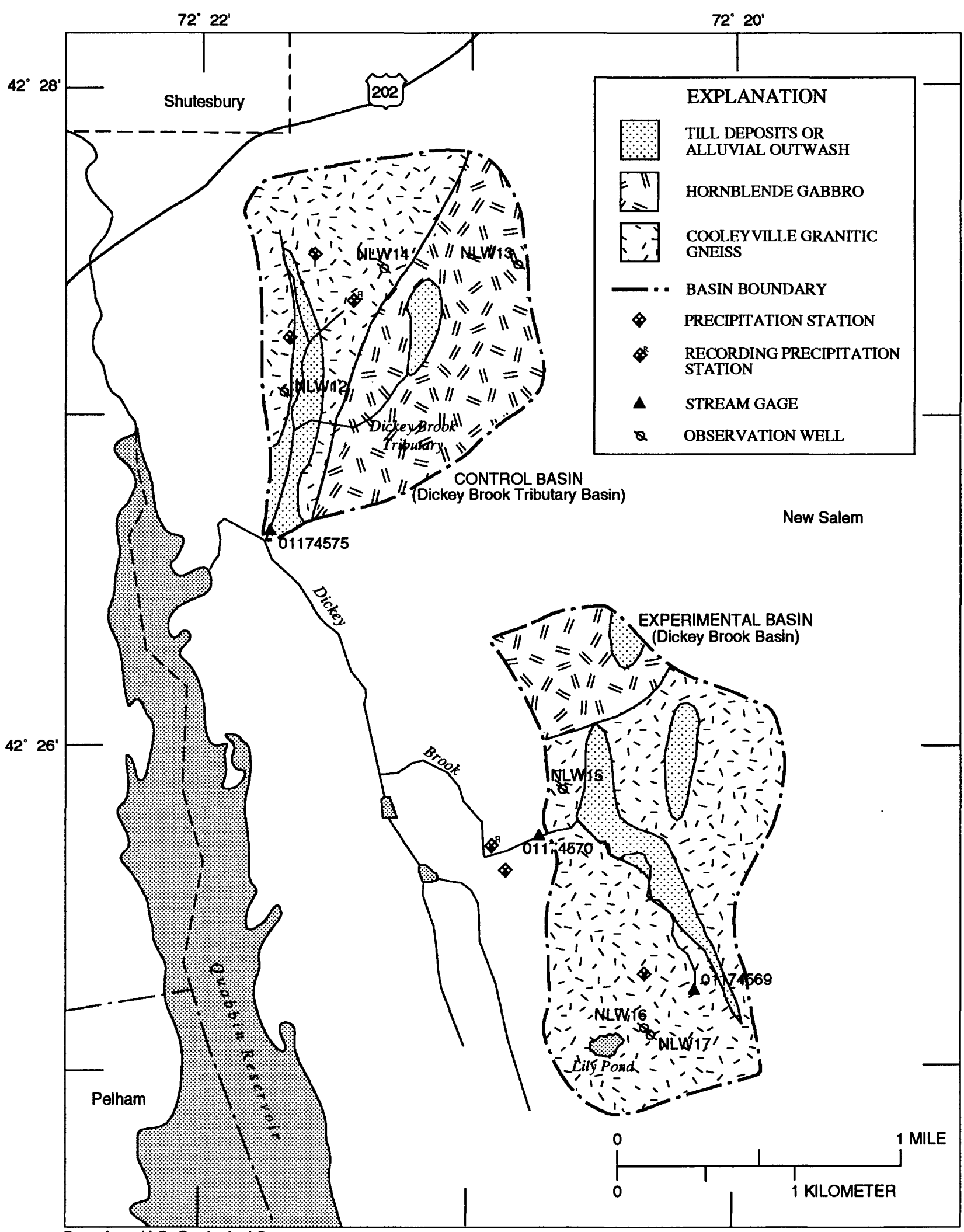

Base from U.S. Geological Survey

Quabbin Reservoir, 1967 Photorevised, 1979

Figure 2. Geology of the control and experimental basins near Quabbin Reservoir, central Massachusetts. 


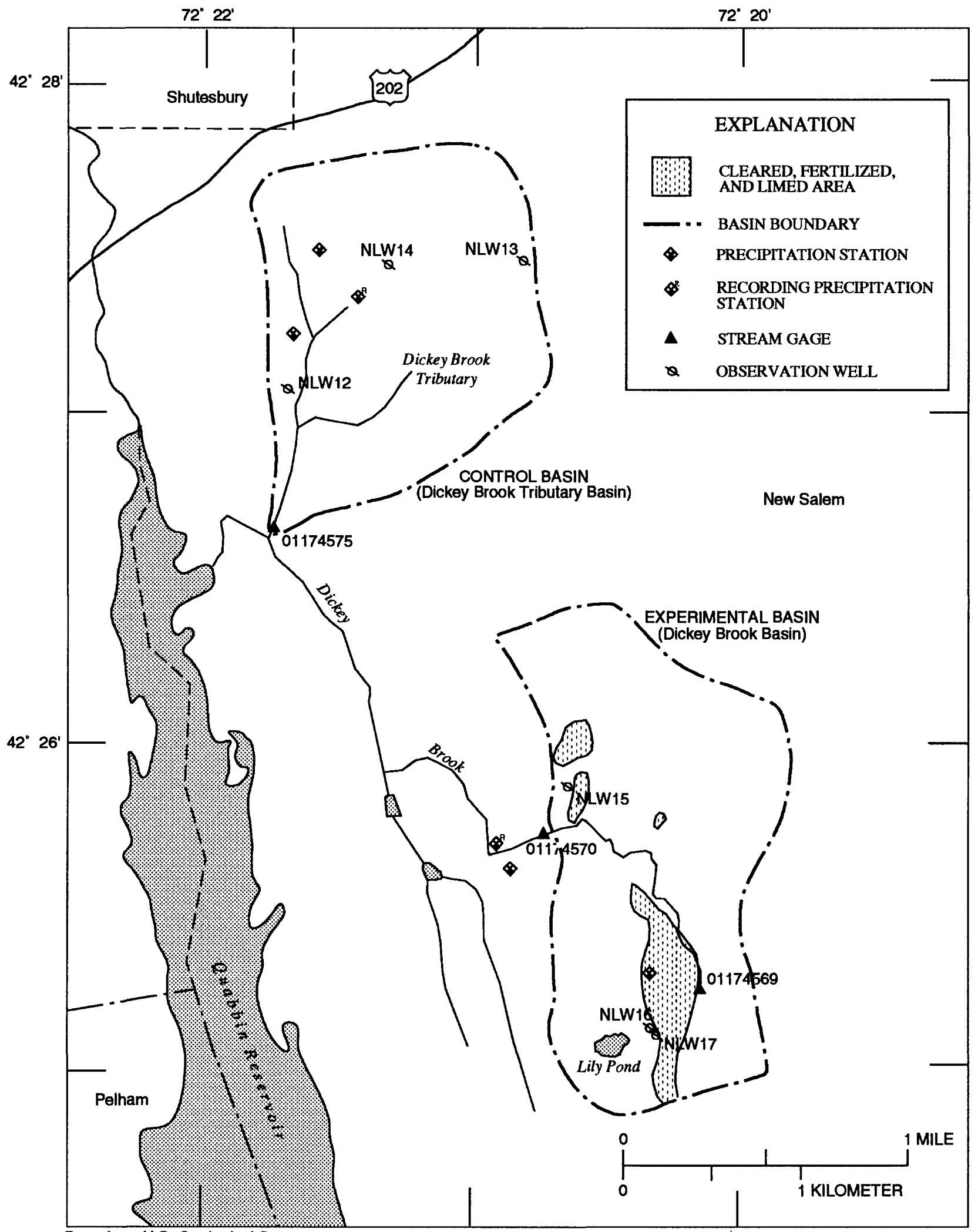

Base from U.S. Geological Survey

Quabbin Reservoir, 1967 Photorevised, 1979

Figure 3. Areas of forest clearing, fertilization, and liming in the experimental basin near Quabbin Reservoir, central Massachusetts. 
Table 1. Summary of forest-clearing, fertilization, and liming treatments in the experimental basin, Dickey Brook Basin, central Massachusetts

$[--$, not applicable $]$

\begin{tabular}{|c|c|c|c|c|c|c|c|}
\hline \multirow{2}{*}{ Area } & \multicolumn{2}{|c|}{ Period of activity (date) } & \multicolumn{2}{|c|}{ Land area (hectare) } & \multicolumn{3}{|c|}{ Basal area (percentage of watershed) } \\
\hline & \multicolumn{7}{|c|}{ Forest clearing } \\
\hline \multicolumn{8}{|l|}{ Initial clearing: } \\
\hline Lily Pond area & $10 / 22 / 86$ & $4 / 1 / 87$ & 21.4 & 7.8 & 19.1 & 3.5 & 22.6 \\
\hline Basin outlet area & $10 / 22 / 86$ & $4 / 1 / 87$ & .5 & 1.5 & .5 & .7 & 1.2 \\
\hline \multicolumn{8}{|l|}{ Final clearing: } \\
\hline Basin outlet area & $10 / 22 / 88$ & $12 / 8 / 88$ & 6.5 & 5.7 & 5.8 & 2.5 & 8.3 \\
\hline Total - initial + final & -- & -- & 28.4 & 15.0 & 25.4 & 6.7 & 32.1 \\
\hline \multicolumn{8}{|c|}{ Additional treatments in area northeast of Lily Pond } \\
\hline $9 / 87$ & \multicolumn{2}{|c|}{4.1} & \multicolumn{5}{|c|}{ Seeding with field mix } \\
\hline $10 / 5 / 87$ & \multicolumn{2}{|c|}{4.9} & \multicolumn{5}{|c|}{$\begin{array}{l}\text { Fertilizer [1, } 415 \text { kilogram } 20-10-10 \text { (nitrogen-phosphorus-potassium)] } \\
\text { applied to all of field-mix area and part of rye grass area }\end{array}$} \\
\hline $9 / 28 / 88$ & \multicolumn{2}{|c|}{6.1} & \multicolumn{5}{|c|}{ Lime applied ( 34.5 metric tons) } \\
\hline
\end{tabular}

\section{METHODS OF STUDY}

Intensive data collection for the pre-treatment characterization of the water quality and hydrology of the two basins began in February 1985. Data collection continued through the treatment period until the end of September 1989. Stream stage was recorded at 15-minute intervals at the control basin outlet, the experimental basin outlet, and a headwater site in the experimental basin (fig. 1). Other data-collection activities included continuous recording of precipitation in or near the basins, weekly collection of precipitation samples for chemical analysis, biweekly surfacewater sample collection (augmented by automated sample collection during high flow), weekly measurement of ground-water levels, and collection of groundwater samples every 2 months.

\section{Hydrologic Data Collection}

Precipitation volumes were measured by a continuous-recording rain gage in the control basin and another downstream from the outlet of the experimental basin. Two nonrecording rain gages in or near each basin were monitored weekly in 1985 to assess areal variations in precipitation quantity and to serve as backup for the recording gage.

The three streamflow-gaging stations are shown in figure 1 . The gages at the two basin outlets were equipped with stage-sensing manometers linked to digital recorders that recorded gage height every 15 minutes. Gage-height-discharge rating curves were developed from periodic measurements at the sites. These two gages had natural controls (no weir structures). The headwaters gage in the experimental basin was downgradient from the area where most of the clearing and thinning was done. During the pre-treatment period, instantaneous streamflow measurements were made intermittently at this site. In July 1986, a few months before the clearing was begun, a V-notch weir with a pressure transducer for stage recording was installed.

Streamflow was calculated from stream gage heights based on standard techniques applied at USGS gaging stations (Rantz and others, 1982). The base-flow component of streamflow was separated on the basis of the graphical technique of Davis and DeWeist (1966). 
Three observation wells were installed in each basin (fig. 1). All were completed in unconsolidated deposits to the apparent depth of the bedrock surface (except for one well purposely screened in more shallow till). The wells were cased with polyvinylchloride (PVC), and each was completed with $1.5 \mathrm{~m}$ of PVC screen. Water levels in wells were measured weekly. Well NLW15 in the experimental basin was in the flood plain close to the basin outlet. Wells NLW 16 and NLW17 were in the headwaters of the experimental basin. Well NLW12 in the control basin was near the edge of a wetland area and also near to the basin outlet. Wells NLW 14 and NLW13 were in well-drained uplands in the headwaters of the control basin.

\section{Water-Quality Data Collection}

Weekly precipitation-quality samples were collected with an Aerochem Metrics Model $301^{2}$ wetfalldryfall collector at a site in New Salem about $8 \mathrm{~km}$ north of the control basin (fig. 1). Precipitation samples were analyzed for 11 selected constituents (table 2). Because the inherent variability of precipitation chemistry precludes the use of a model to simulate concentrations when data are missing, data from the National Atmospheric Deposition Program (NADP) site at Quabbin Observatory (Bigelow, 1982), $5 \mathrm{~km}$ south of the study area, were used to assemble a complete record of weekly precipitation quantity and quality data. (NADP data were used on average, 1 week for every 10 weeks of record.) The New Salem precipitation collector was sampled each Tuesday to coincide with the sampling schedule of the (NADP); precipitation data from the NADP were used in some of the data analyses.

Surface-water samples were collected every 2 weeks from the centroid of flow at each of the two basin outlet gages, and intermittently from the headwaters gage in the experimental basin. Samples were analyzed for 11 selected constituents (table 2). Surface-water samples were collected more frequently during spring snowmelt and selected storms to ensure an adequate representation of high flow.

Samples were collected from the six wells every 2 months and were analyzed for 11 selected constituents (table 2). The wells were purged at least 1 week before each sampling by evacuating several well volumes with

\footnotetext{
${ }^{2}$ Use of the brand names in this report is for identification purposes only and does not constitute endorsement by the U.S. Geological Survey.
}

Table 2. Chemical constituents analyzed for the study near Quabbin Reservoir, central Massachusetts

\begin{tabular}{ll}
\hline \multicolumn{1}{c}{ Constituent } & Abbreviation \\
\hline Hydrogen ion & $\mathrm{H}+$ \\
Calcium & $\mathrm{Ca}$ \\
Magnesium & $\mathrm{Mg}$ \\
Sodium & $\mathrm{Na}$ \\
Potassium & $\mathrm{K}$ \\
Alkalinity & $\mathrm{ALK}$ \\
Sulfate & $\mathrm{SO}_{4}$ \\
Chloride & $\mathrm{Cl}$ \\
Silica & $\mathrm{Si}$ \\
Nitrate & $\mathrm{NO}_{3}$ \\
Dissolved organic carbon & $\mathrm{DOC}$ \\
\hline
\end{tabular}

a centrifugal pump, and then a second time 1 to 2 days before samples were collected. Samples were collected with a bailer.

Specific conductance and $\mathrm{pH}$ were measured in all samples generally within 24 hours of collection. Alkalinity was measured in stream samples and groundwater samples by fixed-endpoint titration to $\mathrm{pH} \mathrm{4.5}$. Concentrations of the other nine selected constituents (table 2) were determined at the USGS central laboratory in Arvada, Colo., by standard methods (Fishman and Friedman, 1989). Sediment samples were analyzed at the USGS laboratory in Harrisburg, $\mathrm{Pa}$., to determine suspended-sediment concentrations.

\section{Hydrologic Data Analysis}

\section{Calculations of Flow}

Daily mean streamflows from the outlets of the control and experimental basins during the pre- and post-treatment periods were analyzed to determine the effects of selective forest clearing on the hydrology of the experimental basin. Daily mean streamflows of the experimental basin were regressed on daily mean streamflows of the control basin separately for the preand post-treatment periods. The slopes and the intercepts of the two regression equations were tested for statistical differences by analysis of covariance (Helsel and Hirsch, 1992). A significant change in the 
slope and (or) intercept of the two equations would indicate that selective forest clearing caused an alteration in the hydrology of the experimental basin.

\section{Construction of Flow-Duration Curves}

A second approach to detect the effect of selective forest clearing on the hydrology of the experimental basin is flow-duration curves. A flow-duration curve, computed from the daily mean streamflows, shows the percentage of time a given flow is exceeded. The shape of a flow-duration curve is affected by the runoff characteristics of a specific basin, and it also reflects the climatic regime for the period of record from which the data are derived. Flow-duration curves were generated for both the pre- and post-treatment periods for each basin. The four flow-duration curves allowed a comparison of the flows from both basins during the same time period. The regression equation developed from the pre-treatment flow data was used to estimate daily mean flows for the post-treatment period as if no clearcutting was done in the experimental basin. An additional pair of flow-duration curves was generated to compare the estimated flows to the actual flows during the post-treatment period in the experimental basin.

\section{Calculatlons of Evapotranspiration}

Monthly potential evapotranspiration at the control and experimental basins was estimated by the Thornthwaite method (Thornthwaite and Mather, 1955). Air temperature is applied in the method as an index of the energy available for evapotranspiration and makes no correction for different vegetation types. The empirical formula developed by Thornthwaite for the continental United States is

$$
E T=1.6\left(\frac{10 T_{a}}{I}\right)^{a}
$$

where
$E T$ is potential evapotranspiration, in centimeters per month,
$T_{a}$ is mean monthly air temperature, in degrees Celsius,
$I$ is an annual heat index, and
$a$ is a computed coefficient.

The annual heat index is computed as follows:

$$
I=\sum_{i=1}^{12}\left(\frac{T_{a i}}{5}\right)^{1.5}
$$

where

$i$ is the month of the year

The coefficient a is computed as follows:

$$
\begin{array}{r}
a=0.49+(0.0179) I-(0.0000771) I^{2}+ \\
(0.000000675) I^{3}
\end{array}
$$

Potential evapotranspiration computed from equation 1 was adjusted by a correction factor for monthly sunshine duration. During periods of normal or above-normal precipitation, estimated monthly potential evapotranspiration for a forested region in the humid northeastern United States is a reasonable approximation of actual monthly evapotranspiration (Dunne and Leopold, 1978).

The change in evapotranspiration in the experimental basin during the post-treatment period was estimated as the difference between the actual daily flow and the estimated daily flow calculated from the regression equation that was developed from the pretreatment daily mean flows of both basins. Annual estimates of the change in evapotranspiration were made by aggregating the daily differences.

\section{Water-Quality Data Analysis}

The general validity of the chemical analysis on each sample was evaluated on the basis of ion balance. Samples for which ion-balance discrepancies greater than 10 percent were eliminated from the data base with the exception of low-ionic-strength precipitation samples; for precipitation samples with total ionic composition less than $100 \mu \mathrm{eq} / \mathrm{L}$, an ion-balance discrepancy of up to 30 percent was tolerated. Additionally, data from each sampling location were screened for internal consistency by evaluating outliers on time plots and (or) concentration-discharge plots. Most outliers could be traced to recording of incorrect time or date, or erroneous stream discharge. Outliers that could not be rejected on the basis of ion balances and (or) by recording errors were retained in the data base. Occasionally, a precipitation sample was not obtained because of sample contamination or sampler malfunction. 


\section{Solute-Concentrations Models}

Regression models were developed to simulate solute concentrations as a function of streamflow and (or) season following the method of Huntington and others (1994). Instantaneous streamflow was used directly as input to some of the regressions, but various transformations also were made on streamflow to obtain the optimum form of discharge term for each solute. Transformations included a log-transform and a transform of the type $1 /(1+\beta Q)$, where $Q$ is discharge and $\beta$ is a coefficient that is optimized for the best model fit. In addition, for each sampling time, average streamflows for a series of time intervals before the sampling time were calculated. The time periods were 1,6 , and 12 hours, and 1, 2, 5, 10, 15, 30, 45, 60, and 90 days. These average streamflows were applied as an estimate of antecedent flows in the chemical processes. Average streamflows were transformed in the same manner as the instantaneous streamflow to yield the optimum discharge term for each model. No model included more than one streamflow term; that is, either instantaneous or an antecedent average streamflow, or some transformation of either term, was used.

The seasonal component in the regression models was represented by sine and cosine terms with annual periodicity. Inclusion of both sine and cosine terms. as independent variables enabled the models to adjust for phase. For example, if two solutes were characterized by annual concentration cycles that peaked on July 1 and October 1, the model simulating the first solute would place all the weight on the cosine term and would not include a sine term (coefficient of zero), whereas the opposite applies for the second solute.

Models were optimized based on the highest coefficient of determination $\left(r^{2}\right)$, but special attention was paid to model residuals. Models having constantresidual variance (homoscedasticity) were favored over models that may have had a higher $r^{2}$ but a poor distribution of residuals. In particular, models where concentrations were poorly simulated at high flows were rejected because of the important effect of high-flow periods on chemical flux.

The regression models were used not only to calculate fluxes of constituents, but also to gain insight into the processes that affect the solute chemistry in the stream. Model structure, such as whether concentrations increased or decreased with increasing streamflow, or whether the seasonal maximum was in summer or winter, aided in the interpretation of biogeochemical processes in the study basins.

\section{Calculation of Solute Loads}

Solute fluxes in precipitation were calculated from the weekly sample data as the product of solute concentration and weekly precipitation volume. Separate calculations of solute fluxes were made in each basin on the basis of separate measurements of precipitation volume; concentrations were assumed to be the same. Solute fluxes in precipitation were summed by water year.

Stream-solute fluxes were calculated as the summed product of the continuous hydrograph and the continuous chemographs generated from the regression models. Output fluxes were calculated at a 5-minute time step. Residuals from the regression models were used to adjust the calculated concentrations at each time step. Adjustments were based on a linear interpolation of the residuals between the two observations bracketing the time step. For example, the hypothetical model residual for observation $n$ at time $t_{1}$ is $+1 \mu \mathrm{eq} / \mathrm{L}$ and the model residual for the next observation $n+1$ at time $t_{2}$ is $+2 \mu \mathrm{eq} / \mathrm{L}$. At a time exactly intermediate between $t_{1}$ and $\mathrm{t}_{2}$, the interpolated residual is $+1.5 \mu \mathrm{eq} / \mathrm{L}$; thus, $1.5 \mu \mathrm{eq} / \mathrm{L}$ is added to the model-simulated solute concentration before the flux is calculated at that time step. Stream-solute fluxes were summed by water year and normalized to the area of each basin for ready comparison between the two basins.

\section{PRE-TREATMENT HYDROLOGIC CHARACTERISTICS OF EXPERIMENTAL AND CONTROL BASINS}

The hydrology and geology of the two basins are not identical. The control basin has steeper topography and better drainage, as indicated by the smaller extent of wetland areas. The effects of clearing on water yield are less significant in forests with high water tables; wetland areas cause greater evaporation and "luxury consumption" of water by the riparian forest (Verry, 1986). From a chemical standpoint, it was thought that the greater amount of gabbro bedrock in the control basin would make chemical comparisons to the experimental basin problematic.

\section{Precipitation}

Annual precipitation quantities were nearly identical in the two basins during water years 1985-89 (fig. 4). Annual precipitation during this period averaged $1,200 \mathrm{~mm}$ for the control basin and $1,158 \mathrm{~mm}$ 


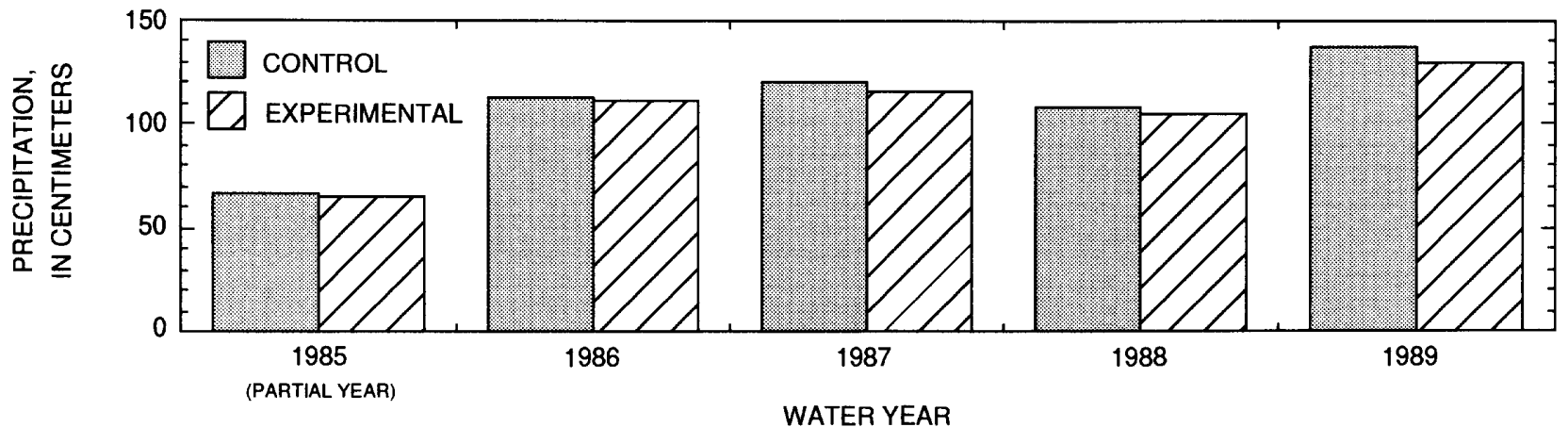

Figure 4. Precipitation in the control and experimental basins, Dickey Brook Basin near Quabbin Reservoir, central Massachusetts, water years 1985-89.

for the experimental basin. The correlation coefficient for monthly precipitation computed from measured daily precipitation at the two sites during the $4 \frac{1}{2}$-year study was 0.979 . Quantities at each of the two nonrecording gages within each basin were usually within $2.5 \mathrm{~mm}$ of the weekly total measured precipitation at the recording gage in that basin.

At a National Weather Service observation station at New Salem (fig. 1), the long-term average annual precipitation derived from nearly 45 years of record is 1,247 mm (National Oceanic and Atmospheric Administration, 1985). Precipitation is evenly distributed throughout the year. Mean monthly precipitation at New Salem for the period of record ranges from 66 to $104 \mathrm{~mm}$. Approximately 20 percent of annual precipitation falls as snow. At New Salem, annual precipitation exceeded the long-term average during each water year of this study: by $51 \mathrm{~mm}$ in 1986, by $187 \mathrm{~mm}$ in 1987, by $50 \mathrm{~mm}$ in 1988, and by $399 \mathrm{~mm}$ in 1989 (Bent, 1994).

Greater precipitation can be expected at the New Salem gage relative to the control and experimental basins because the New Salem gage is at a higher elevation. Bent (1994) showed that precipitation at New Salem averaged 21 percent more than that at the control and experimental basins on an annual basis.

\section{Surface-Water Flow}

The precipitation-runoff characteristics of the two basins under undisturbed conditions were analyzed on the basis of daily mean streamflow data from the pretreatment period of the study. In the only complete water year of the pre-treatment period, water year 1986, mean annual stream discharge was $40.78 \mathrm{~L} / \mathrm{s}$ in the control basin and $45.03 \mathrm{~L} / \mathrm{s}$ in the experimental basin.
During the pre-treatment period, base flow accounted for nearly 75 percent of the total streamflow in both basins (fig. 5). Estimates of the base-flow components from four other basins contributing to the Quabbin Reservoir range from 37 to 73 percent of total stream discharge (Stekl, 1985; Rittmaster and Shanley, 1995).

Hydrographs from the two basins throughout the duration of the pre-treatment period (fig. 5) indicate that the timing of peak flows was very similar. However, the recession following peak flow characteristically was more rapid in the experimental basin relative to recession in the control basin. The experimental basin apparently has less storage capacity than the control basin. Wetlands account for 15 percent of the experimental basin but only for 4 percent of the control basin; therefore, more area in the experimental basin has a water table at or near land surface than in the control basin. Thus, the wetlands function as saturated contributing areas; precipitation and snowmelt on the wetland areas contribute directly to surface-water runoff. A greater proportion of the stormwater leaves the experimental basin as surface flow and less water reaches the underlying aquifer; thus, the hydrograph recession is curtailed.

The flashier response of the experimental basin is consistent with theories on streamflow generation based on topographic considerations. Basins with convergent gentle slopes are more likely than steeper catchments to develop extensive zones of surface saturation near stream channels (Dunne and others, 1975). Precipitation or snowmelt on these saturated contributing areas travels directly to stream channels as saturation-excess overland flow. Although other factors such as depth to bedrock and soil permeability are important, 


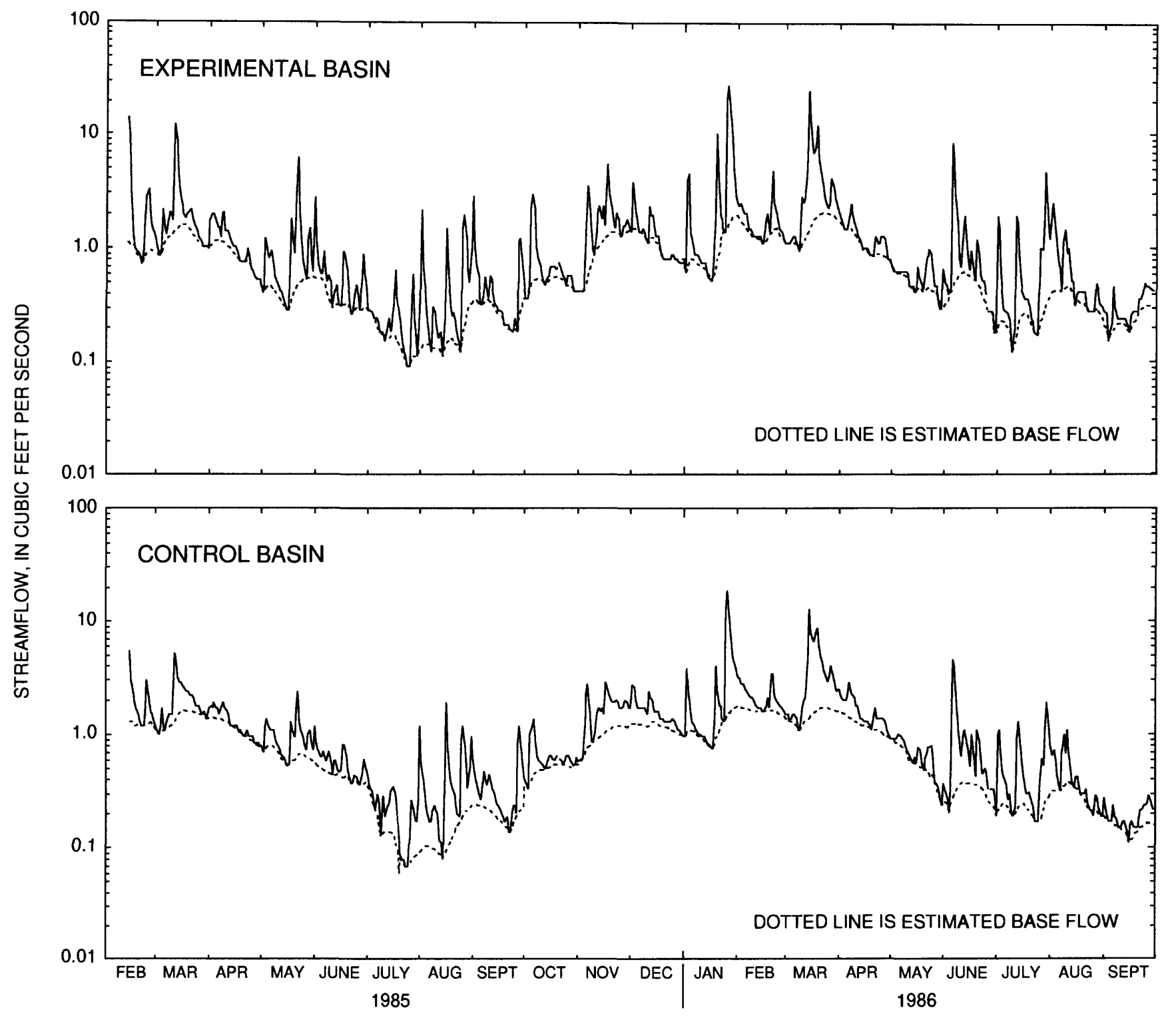

Figure 5. Streamflow and base flow in the experimental and control basins near Quabbin Reservoir, central Massachusetts, during the pre-treatment period, February 1985 through October 1986.

topography alone commonly can account for much of the hydrologic conditions in a basin (Wolock and others, 1990). Topographic indices, which are derived from local slope and the upslope contributing area at each point in a basin, were not computed in this study. However, given the substantially lower average slopes in the experimental basin ( 2 percent compared to 5 percent in the control basin), the experimental basin should have a greater potential to generate rapid runoff during storms and snowmelt than the control basin. The steeper slopes of the control basin could contribute to rapidresponse streamflows only if permeable soils or extensive macroporosity were present to cause a rapid subsurface response; the steep slopes would then enhance rapid downslope flow of water to a stream channel.

The capacity of the control basin to sustain base flow is confirmed by greater flows between the $10^{\text {th }}$ and $70^{\text {th }}$ percentiles in flow-duration curves computed from pre-treatment data (fig. 6). The similarity in the flow-duration curves above the $70^{\text {th }}$ percentile is 


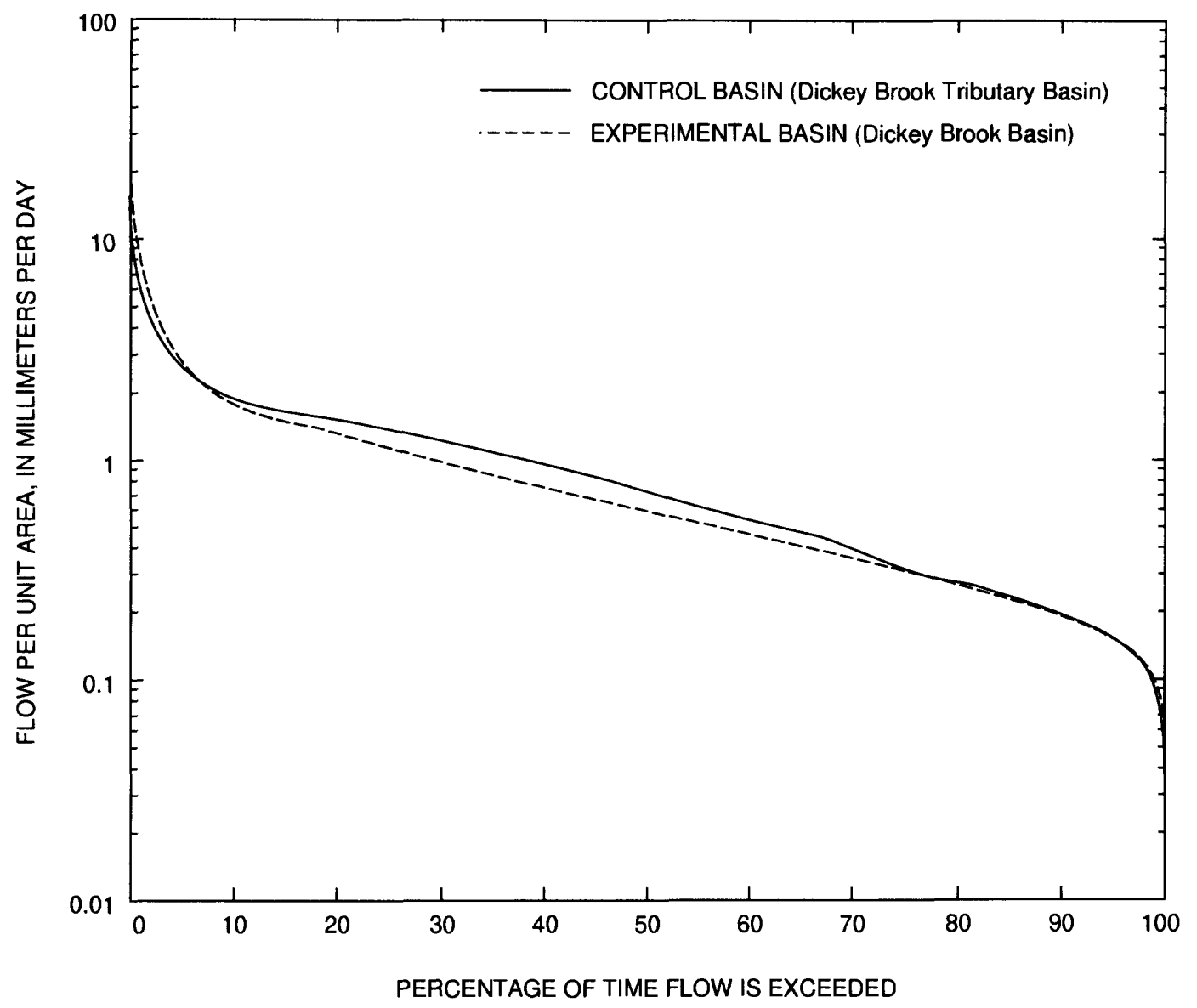

Figure 6. Flow-duration curves for the experimental and control basins near Quabbin Reservoir, central Massachusetts, during the pre-treatment period, February 1985 through October 1986.

indicative of a limit to this base-flow-generating reservoir in the control basin. At low flows, both basins may supply base flow from deeper ground-water sources within similar low permeability substrates.

Peak discharges for various recurrence intervals were estimated for the two basins on the basis of a regional regression model (Wandle, 1983). The peak discharge for a given recurrence interval is a function of the drainage area and the total area of wetlands and ponds in the basin. The estimated 2-year peak flow was $1,560 \mathrm{~L} / \mathrm{s}$ in the control basin and $1,590 \mathrm{~L} / \mathrm{s}$ in the experimental basin. The estimated 100-year peak flow was $9,260 \mathrm{~L} / \mathrm{s}$ in the control basin and $8,440 \mathrm{~L} / \mathrm{s}$ in the experimental basin. The increasing attenuation of peak flows in the experimental basin relative to the control basin is caused by the larger area of wetlands in the experimental basin. As the recurrence interval increases, conversion of the experimental basin to grassland would be expected to increase water yield primarily through increases in base-flow yields (Hornbeck and others, 1993). However, elevated soil moisture as a result of reduced evapotranspiration may also lead to higher peak-storm discharges and higher flows for a given recurrence interval (Verry, 1986).

\section{Ground-Water Levels}

Hydrographs of ground-water levels from one observation well in each of the two basins (fig. 7) show typical responses to seasonal changes in evapotranspiration and recharge. Ground-water levels generally decline during spring and summer (the growing season) where evapotranspiration is greater than recharge. Ground-water levels generally rise during fall and reach their highest levels in early spring in response to recharge from precipitation and snowmelt. Because a greater proportion of the area of 


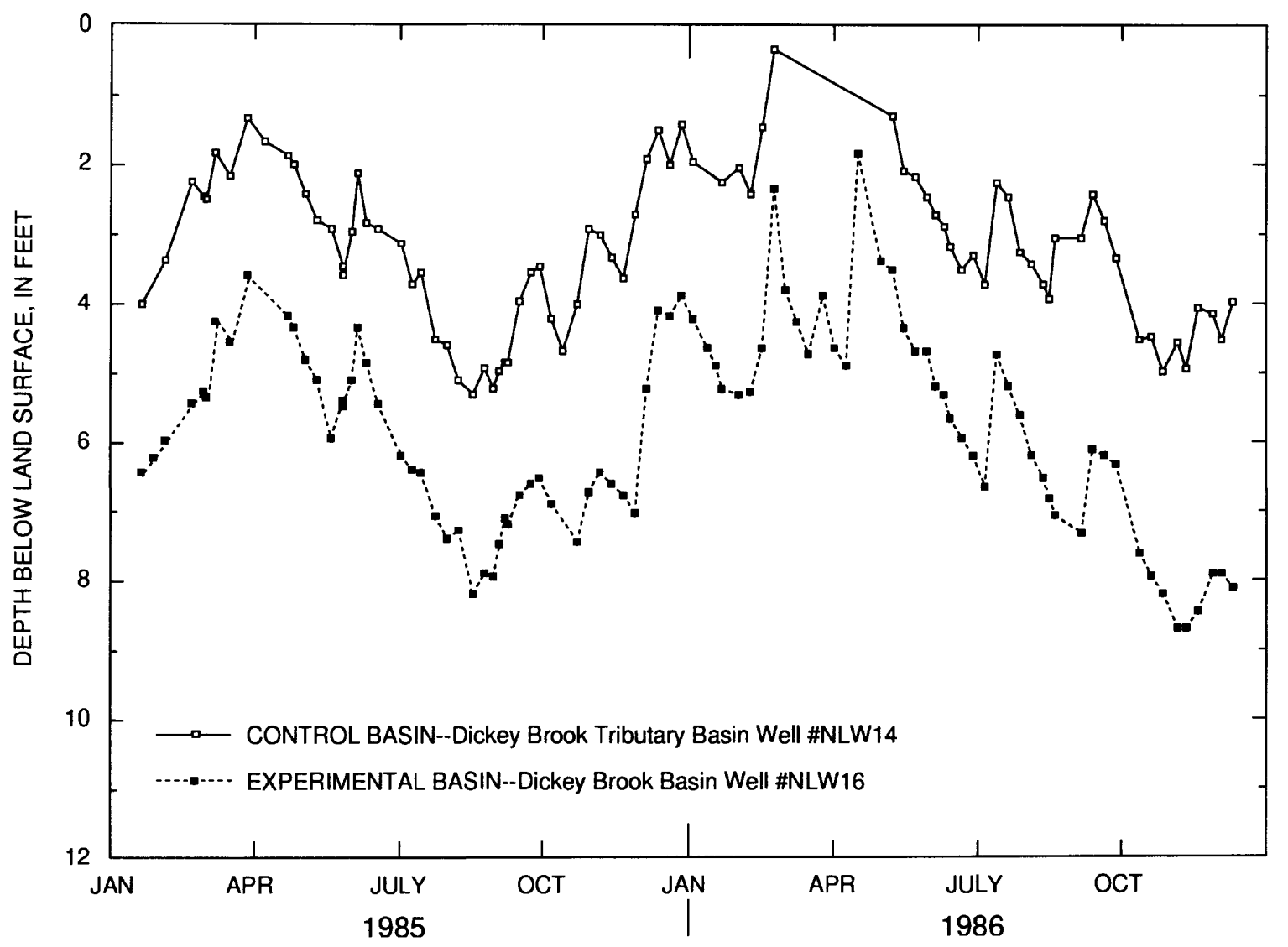

Figure 7. Ground-water levels in two wells in the experimental and control basins near Quabbin Reservoir, central Massachusetts, during the pre-treatment period, February 1985 through October 1986.

the experimental basin is made up of wetlands, the water table in the experimental basin generally is closer to land surface than the water table in the control basin. Although ground-water-level fluctuations vary considerably depending on the topographic setting, data from the small number of wells in this study indicate that ground-water fluctuations in the experimental basin are less variable than those in the control basin.

\section{PRE-TREATMENT WATER-QUALITY CHARACTERISTICS OF EXPERIMENTAL AND CONTROL BASINS}

An overview of $\mathrm{pH}$, alkalinity, and solute concentrations of the major chemical constituents in precipitation, surface water, and ground water from both the experimental and control basins during the pretreatment period is shown in figure 8 . The boxplots summarize the median and range of concentrations for each solute. They provide a format for comparison of solute concentrations among precipitation, ground water, and surface water within each basin and for comparison of surface water and ground water between the two basins.

\section{Precipitation}

Precipitation at the study basins can be characterized as a dilute mixture of sulfuric and nitric acids, as has been described at other sites in the northeastern United States (Likens and others, 1977; Gorham and others, 1984). Hydrogen ion was the dominant cation; the $\mathrm{pH}$ of precipitation ranged from 3.5 to 4.8 (fig. 8). Sulfate tended to dominant over nitrate but by less than the $2: 1$ ratio that is common in precipitation in the northeastern United States (Likens and others, 1977). The sum of base cations (calcium, magnesium, sodium, and potassium) generally balanced less than 20 percent of the strong acid-anion component. Similarly, chloride was a minor component of precipitation. 


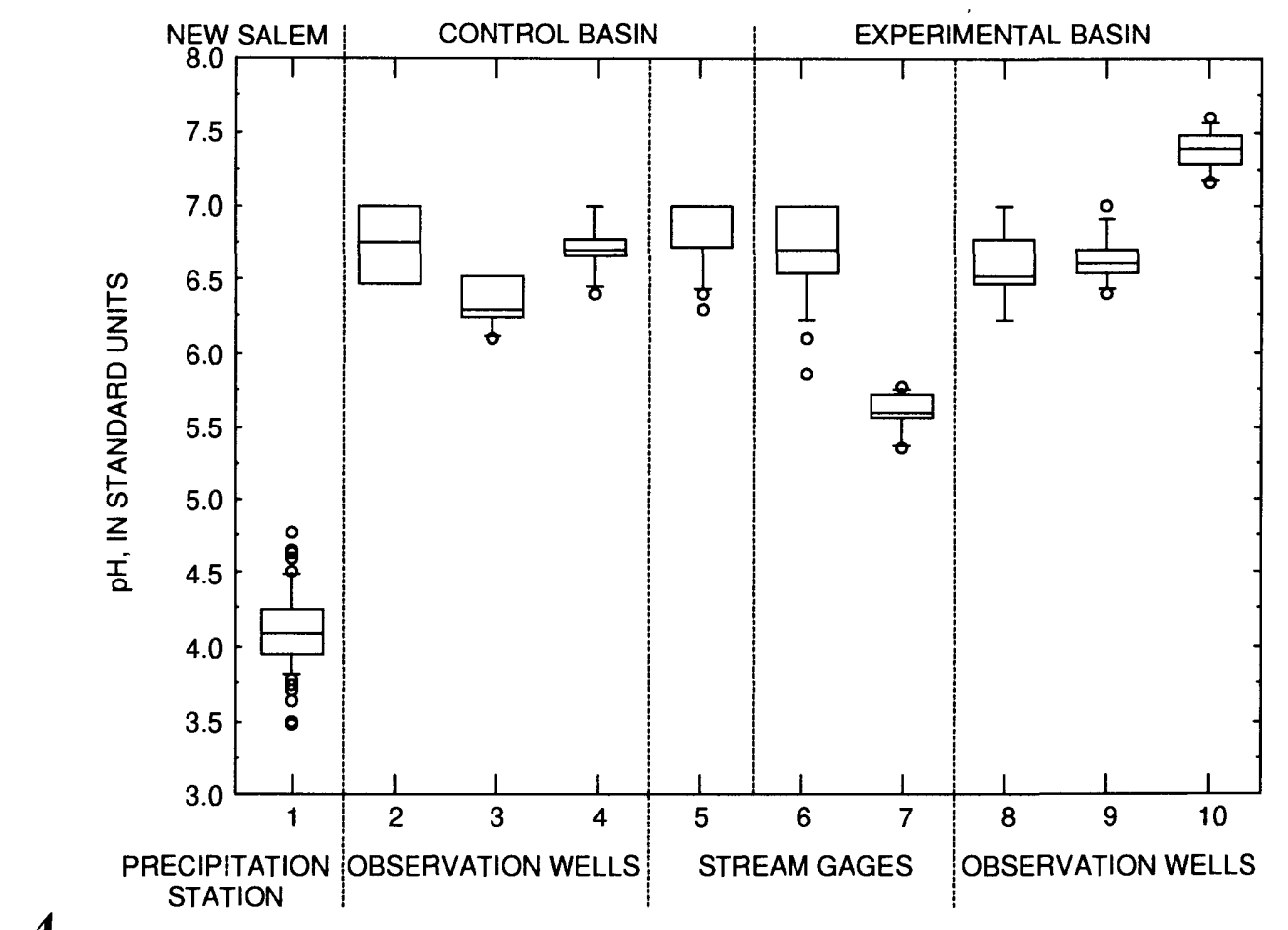

A.

EXPLANATION

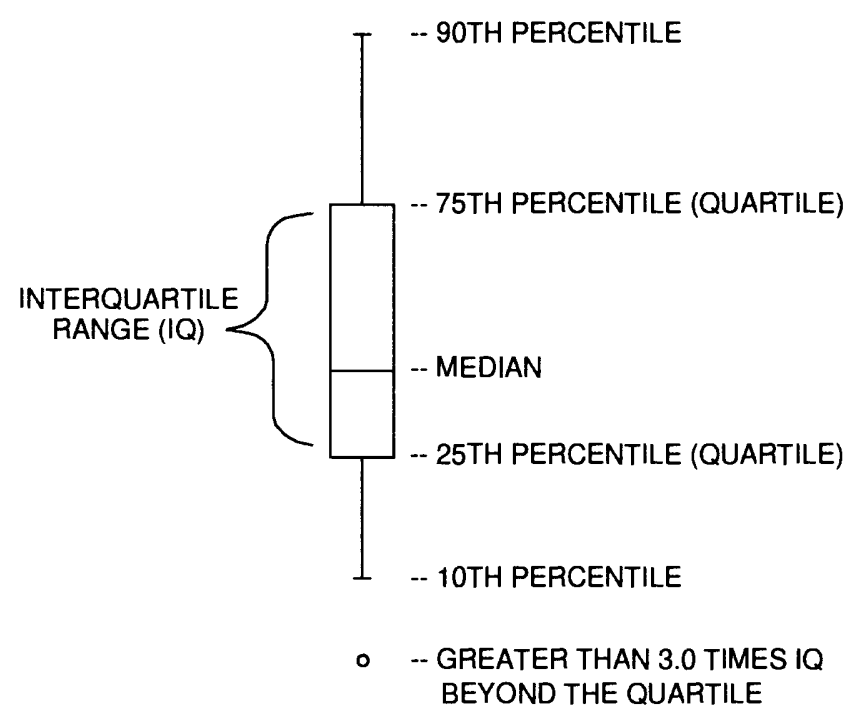

DATA-COLLECTION SITES SHOWN IN FIGURE 1

1 - New Salem Precipitation Station

2 - Observation Well NLW13 (11 feet deep)

3 - Observation Well NLW12 (16 feet deep)

4 - Observation Well NLW14 (22 feet deep)

5 - Control Basin Outlet

6 - Experimental Basin Outlet

7 - Experimental Basin Headwaters Gage

8 - Observation Well NLW15 (11 feet deep)

9 - Observation Well NLW16 (15 feet deep)

10 - Observation Well NLW17 (44 feet deep)

Figure 8. $\mathrm{pH}$, alkalinity, and solute concentrations at New Salem, the control basin, and the experimental basin near Quabbin Reservoir, central Massachusetts, during the pre-treatment period, February 1985 through October 1986. 


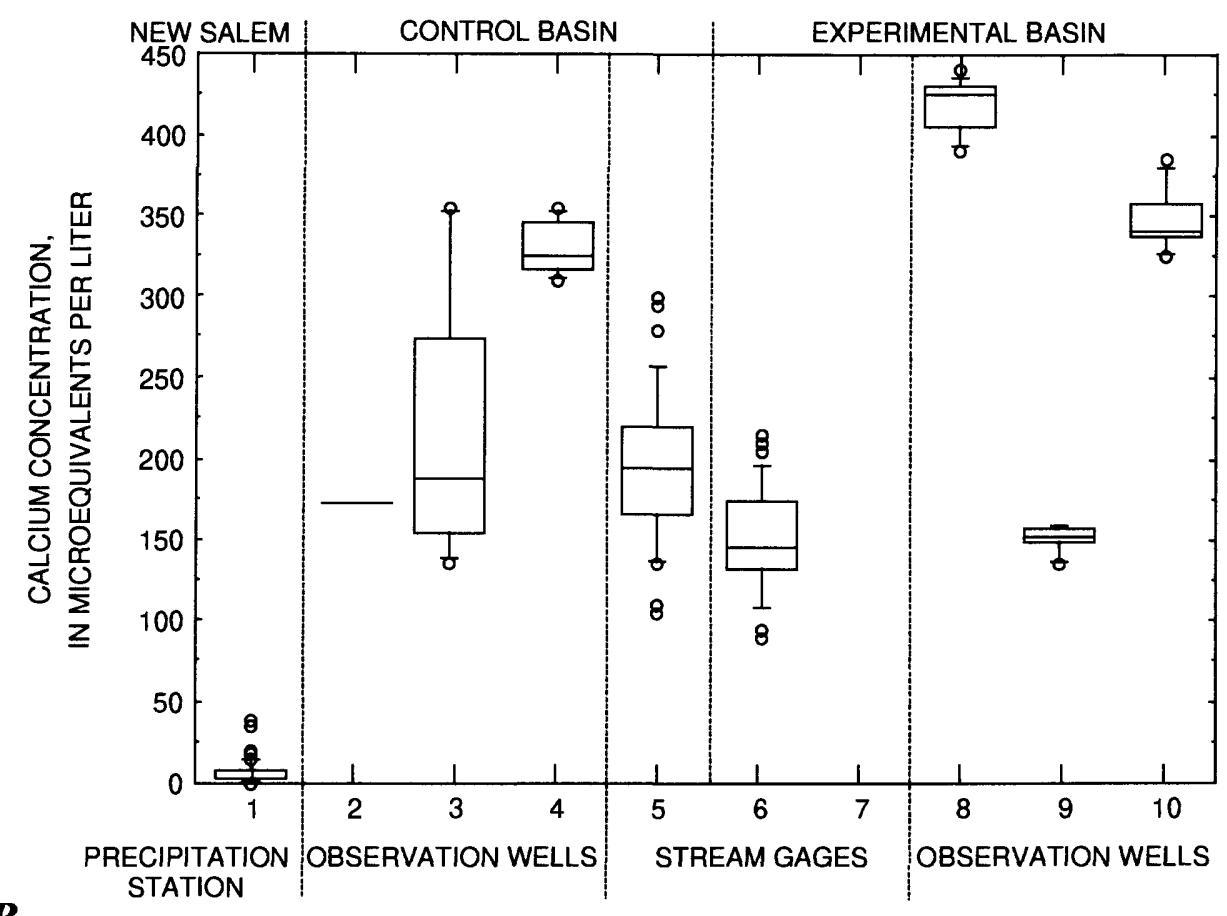

B.

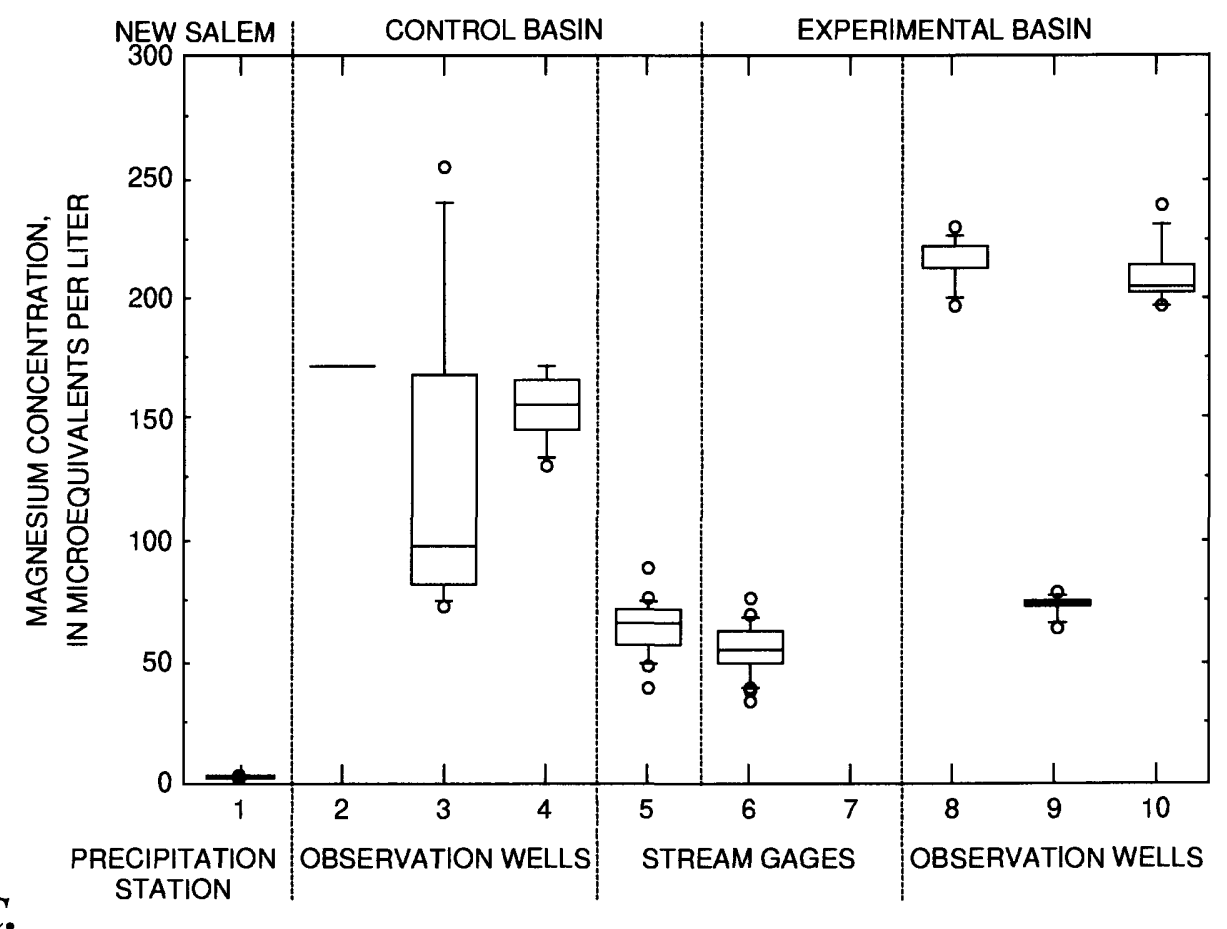

Figure 8.-Continued. 

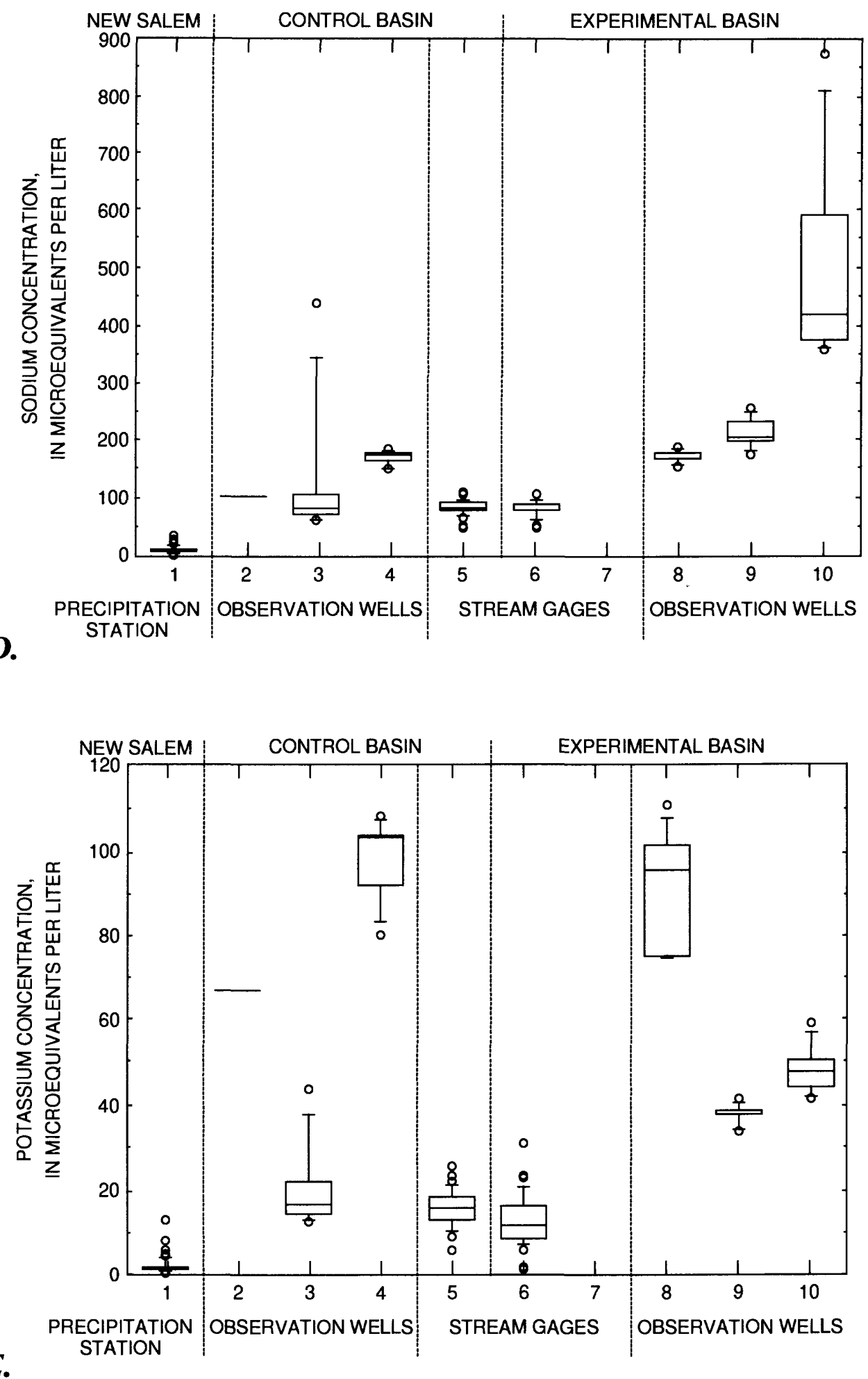

Figure 8.-Continued. 

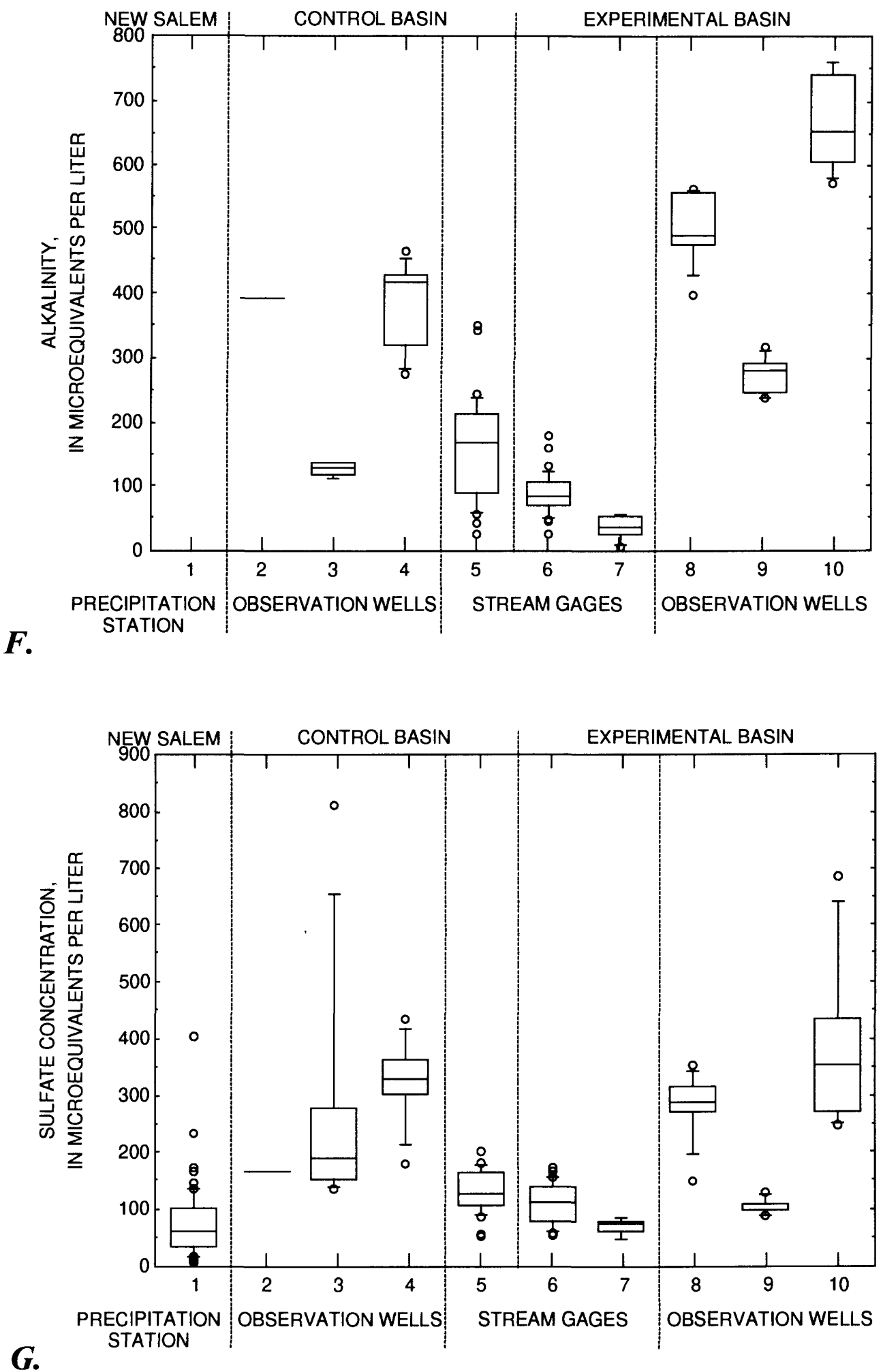

Figure 8.-Continued. 

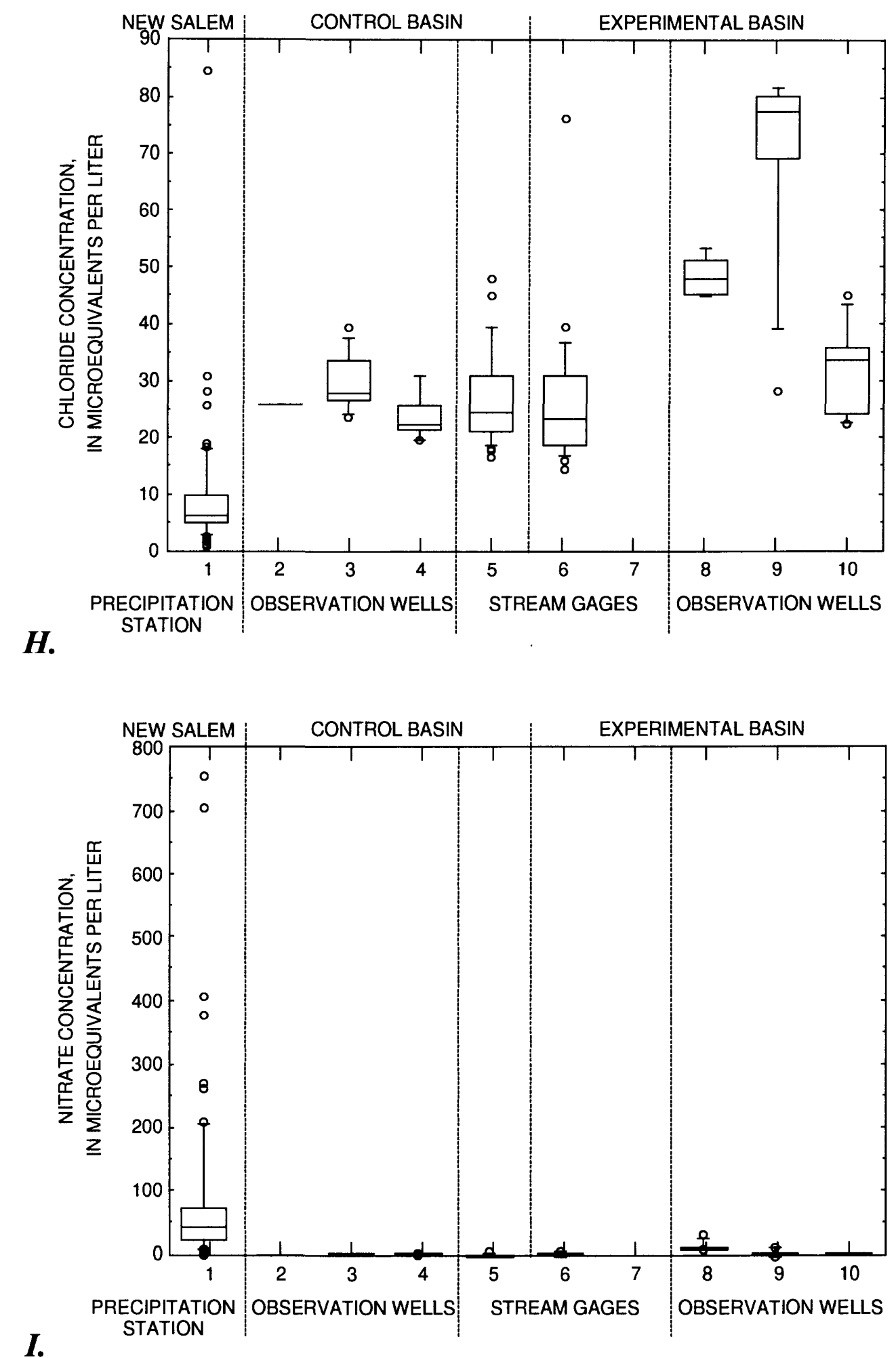

Flgure 8.-Continued. 


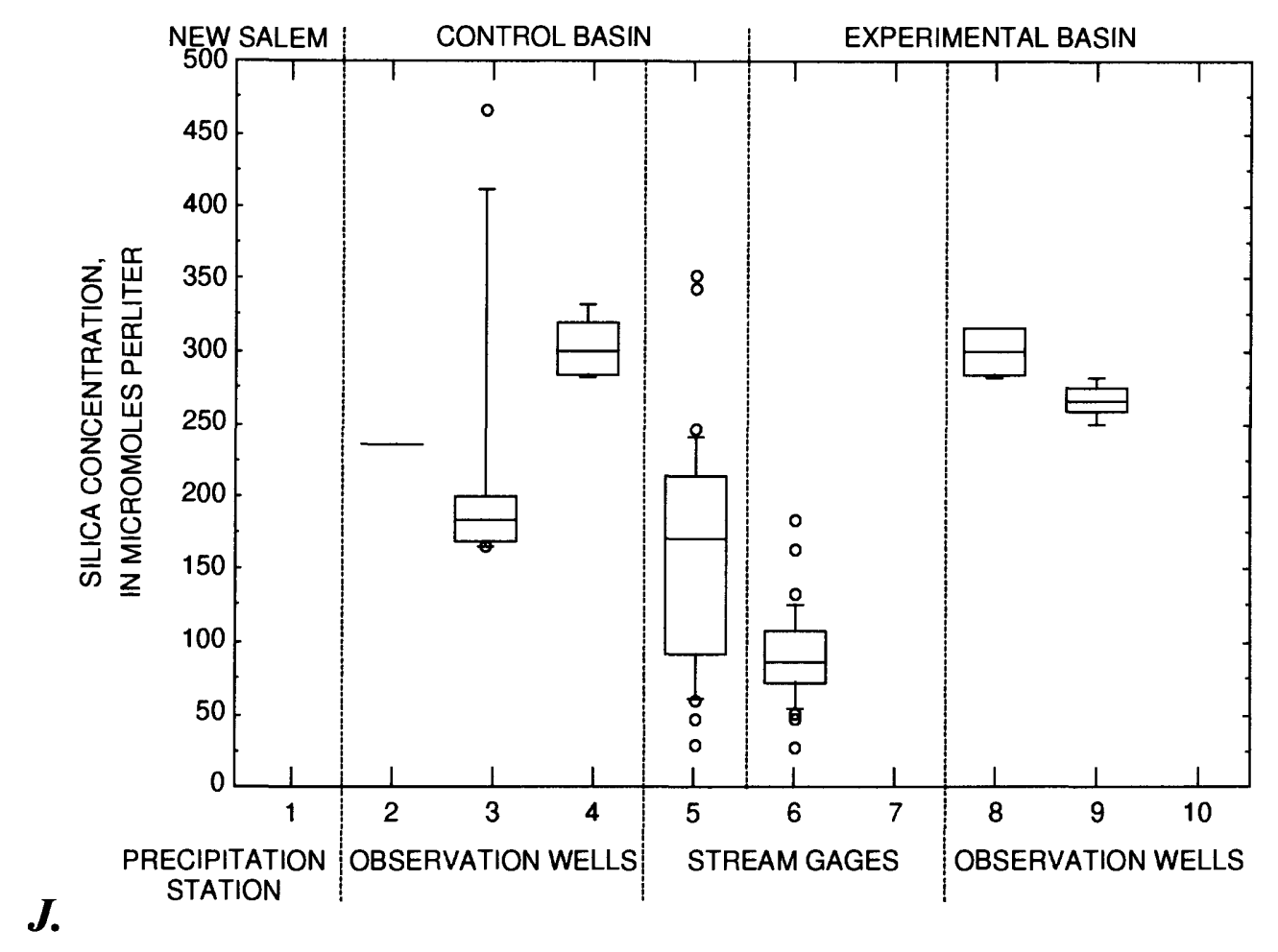

Figure 8.-Continued.

\section{Surface Water}

Biogeochemical processes in each basin transform unbuffered, mildly acidic, low-base-cation precipitation inputs to weakly buffered solutions of calcium magnesium sulfate and calcium magnesium bicarbonate type waters. Water that enters the basins in precipitation participates in biogeochemical reactions as it flows to the stream. As a result, total solute loads increase markedly and relative solute concentrations change. Base cations replace hydrogen ion, bicarbonate becomes a major ion along with sulfate, and nitrate becomes a minor constituent. The small amount of data available from the headwater site in the experimental basin indicates that alkalinity at the headwater site was approximately onehalf the alkalinity at the outlet gage; thus, water at the headwater site has undergone less neutralization.

Despite the differences in hydrology and surficial and bedrock geology among the two basins, solute concentrations (fig. 8) and annual solute budgets (see below) were similar. Two explanations are proposed for the similarity in solute concentrations in the two basins. First, solute chemistry is affected less by bedrock than by soils and unconsolidated materials, which may be more similar between basins than the bedrock. Second, increased solute contributions from the greater percentage of gabbro in the control basin are offset by shorter hydrologic residence times due to the steeper topography and the lower percentage of wetlands in that basin. The case for shorter hydrologic residence time in the control basin is supported by the lower solute concentrations in ground water relative to the experimental basin (fig. 8). In the experimental basin, longer groundwater residence time may be a factor that increased solute concentrations in streamwater.

Some notable differences were found in the surface-water chemistry in the two basins. Concentrations of calcium, magnesium, and potassium all were slightly higher in the control basin (figs. $8 A, 8 B$, and $8 D$ ), whereas alkalinity and concentrations of silica 
were significantly higher in the control basin (figs. $8 E$ and $8 J$ ). These differences can be attributed to the greater percentage of the control basin underlain by the more reactive gabbro. Sulfate concentrations also were slightly higher in the control basin (fig. $8 G$ ), indicating that sulfide mineral weathering may occur in the control basin and (or) that sulfate reduction may occur in the wetlands of the experimental basin.

Calcium magnesium sulfate and calcium magnesium bicarbonate type waters were present in streamwater in the two basins at various times during the pretreatment period are indicated in the trilinear diagrams shown in figure 9 . These diagrams were plotted separately for streamflows of less than and streamflows greater than $21.2 \mathrm{~L} / \mathrm{s}$ (this amount of streamflow approximately separates the base flow and the surfacerunoff components of streamflow). This division illustrates the change from calcium magnesium bicarbonate to calcium magnesium sulfate type water as streamflow increases. Very little change was measured in the cation ratios of the high-flow and base-flow waters.

\section{Ground Water}

In general, the concentrations of constituents from the experimental basin were higher than those in the control basin. Samples from two or more wells in the experimental basin had median concentrations of calcium, magnesium, sodium, chloride, and alkalinity that were higher than the corresponding medians for ground-water samples in the control basin. Samples from the deepest well NLW 17
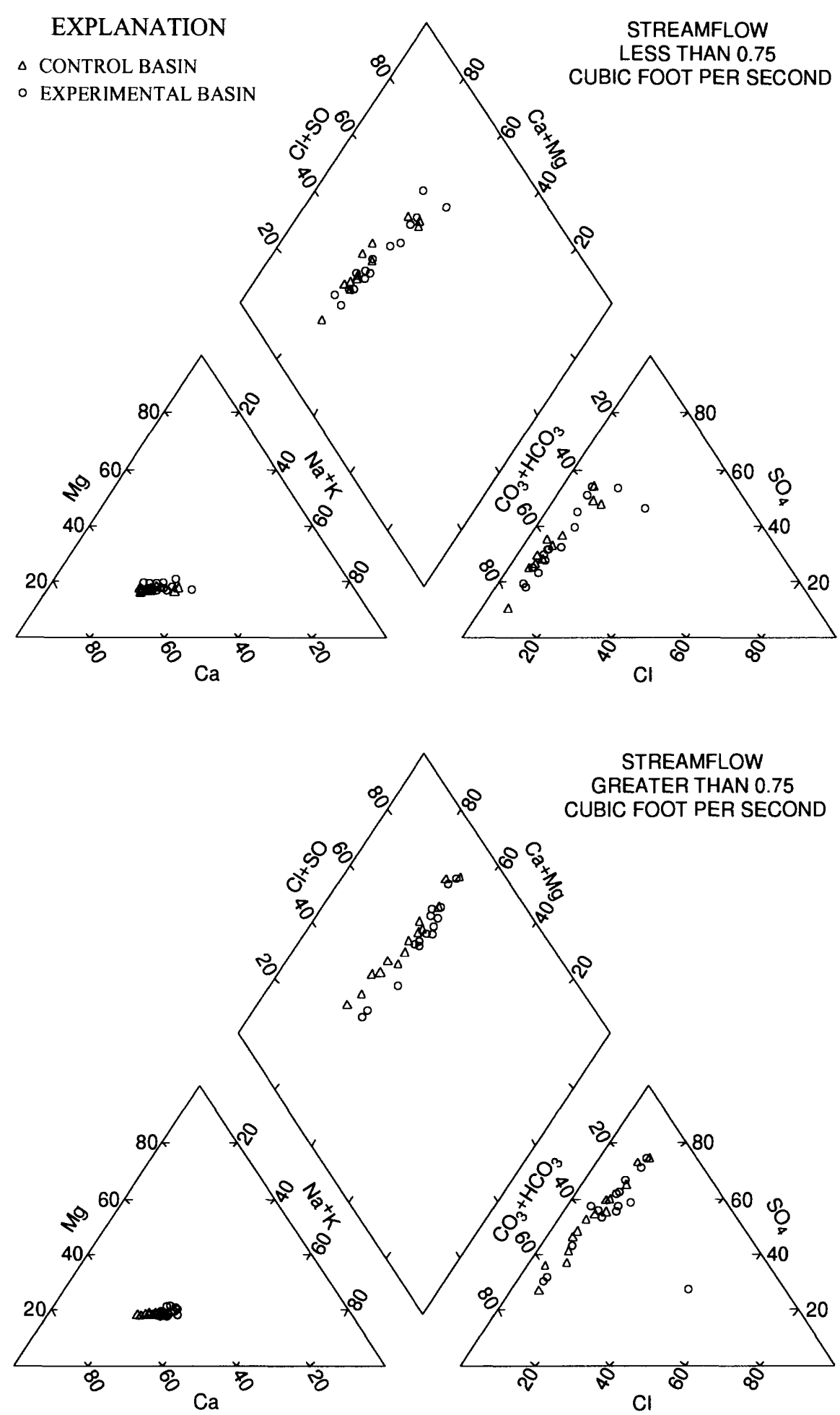

PERCENTAGE OF TOTAL MILLIEQUIVALENTS PER LITER

Figure 9. Percentage of chemical constituents in streamwater from the control and experimental basins, Dickey Brook Basin, central Massachusetts, during the pre-treatment period, February 1985 through October 1986. 
(13.4 m) generally had higher concentrations of most constituents than samples from shallower wells $(3.35$ and $6.7 \mathrm{~m})$. None of the samples from the wells from either basin was considered to be completely representative of the typical ground-water quality of that basin.

Judging from physical characteristics of the basin, ground water in the experimental basin would be expected to have higher solute concentrations than ground water in the control basin. The experimental basin has a gentler slope and a greater proportion of wetlands (15 percent as compared to 4 percent). Thus, ground water would be expected to have a longer residence time in the experimental basin. Seasonal ground-water fluctuations in the experimental basin were less variable, and mean water levels were closer to land surface. Differences in ground-water chemistry between the two basins should not be rigorously compared because the number of sites is small (three wells in each basin) and because the spatial variability of the ground-water chemistry is typically large. Trilinear diagrams that depict the ratios of cations and anions in ground-water (fig. 10), however, indicate that the percentage of sulfate was higher in the control basin than in the experimental basin. The relatively high sulfate concentration may be derived from weathering of sulfide minerals, as discussed previously, or from atmospheric sulfate that has not been removed from solution. Alternatively, it may reflect greater sulfate reduction in the more wetland-dominated experimental basin. Bicarbonate was proportionally higher in the experimental basin, indicating a greater degree of weathering than in the control basin.

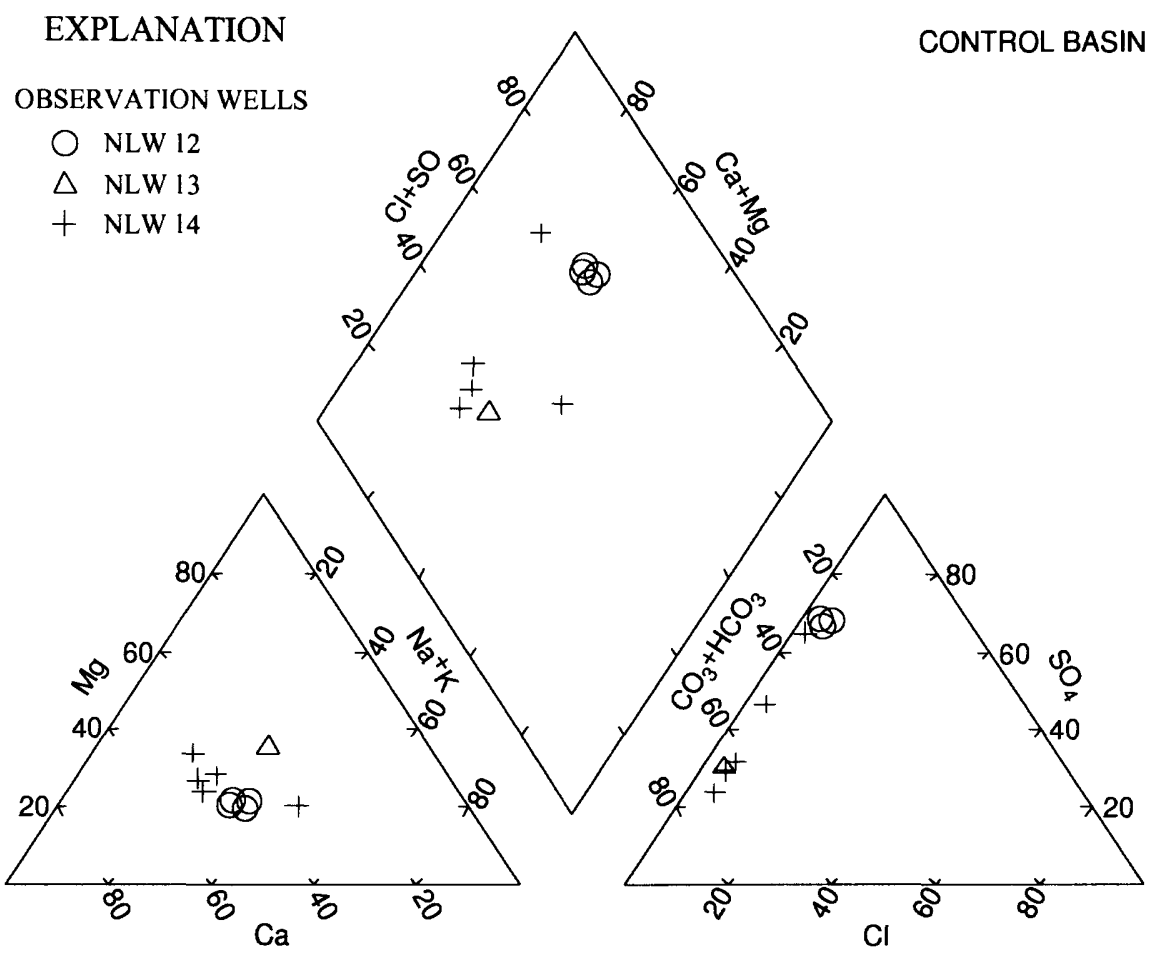

EXPLANATION

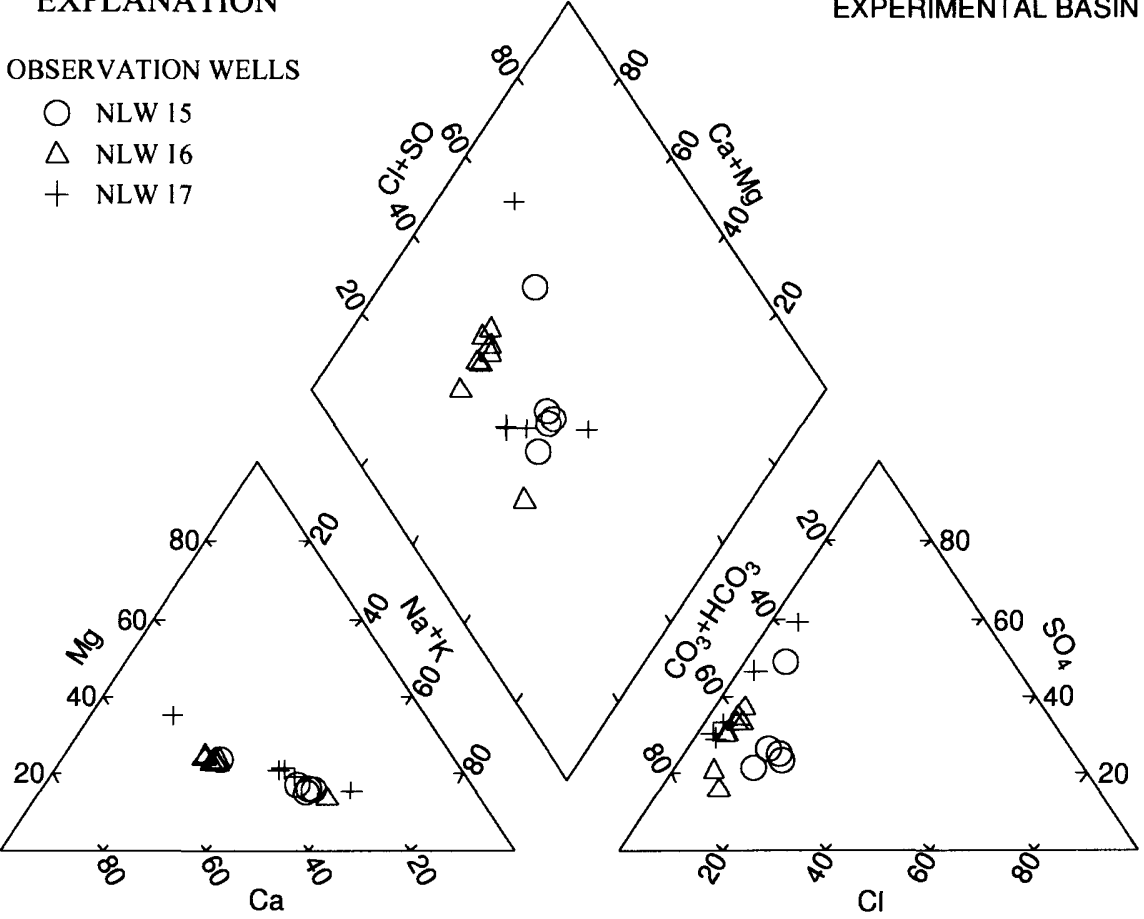

PERCENTAGE OF TOTAL MILLIEQUIVALENTS PER LITER

Figure 10. Percentage of chemical constituents in ground water from the control and experimental basins, Dickey Brook Basin, central Massachusetts, during the pre-treatment period, February 1985 through October 1986. 


\section{EFFECTS OF SELECTIVE FOREST CLEARING ON HYDROLOGY}

Thus far, the control basin (Dickey Brook Tributary) and the experimental basin (Dickey Brook) have been compared and contrasted on the basis of pretreatment conditions. In the remainder of the report, the overall effect of selective forest clearing and partial conversion to field cover on the hydrology of the experimental basin is assessed. The next section examines the effect on the hydrology, and the subsequent section examines the effect on water quality.

\section{Changes in Surface-Water Flow}

The effect of selective forest clearing on streamflow can be assessed by a comparison of annual totals of precipitation and runoff (streamflow/basin area) from the two basins (fig. 11). During water year 1987, the year in which most of the forest clearing took place, runoff in the experimental basin was more than $50 \mathrm{~mm}$ greater than runoff in the control basin. In each of the other years, runoff from the experimental basin was slightly less than runoff from the control basin. The increased runoff from the experimental basin during water year 1987 began in March and extended through the end of the growing season in October; the greatest increase was in March and April 1987 (fig. 12). This period of increased streamflow coincided with the completion of the first and largest phase of the selective forest clearing. Because the forest clearing did not begin until the end of the previous growing season, higher streamflows during spring runoff most likely resulted from increased insolation on the snowpack where the canopy had been removed. Continued high streamflows in the experimental basin during the growing season may be attributed to reduced water demand from the reduced forested area.

Another way to evaluate the effect of forest clearing is to compare the pairs of flow-duration curves from each basin for the pre- and post-treatment periods (figs. 6 and 13). The pre-treatment curves indicate that the hydrologic response of the experimental basin is more rapid than that of the control basin. The experimental basin had high peak flows, as shown by the high curve in the 0 - to 10 -percent range (fig. 6).

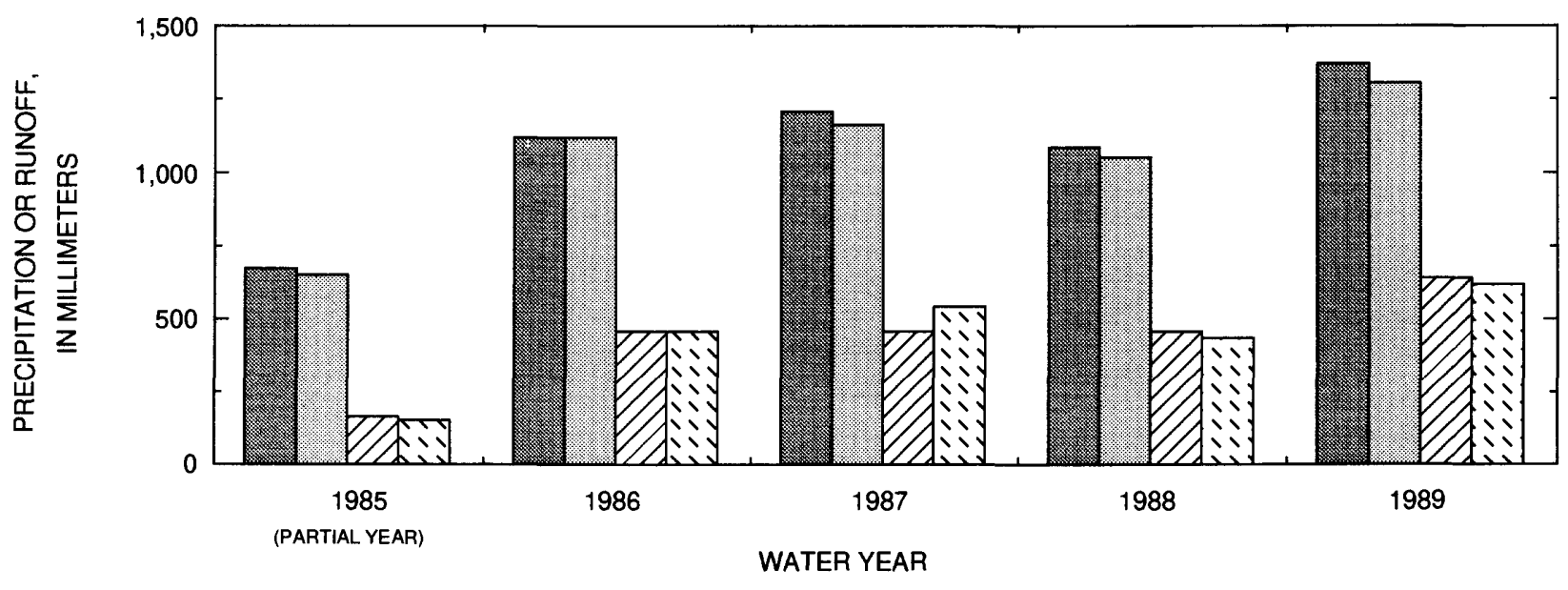

EXPLANATION

CONTROL BASIN - PRECIPITATION

EXPERIMENTAL BASIN - PRECIPITATION

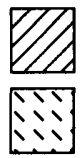

CONTROL BASIN - RUNOFF

EXPERIMENTAL BASIN - RUNOFF

Figure 11. Annual precipitation and annual runoff at the control and experimental basins, Dickey Brook Basin, central Massachusetts, water years 1985 through 1989 (data from water year 1985 are for February through September only). 

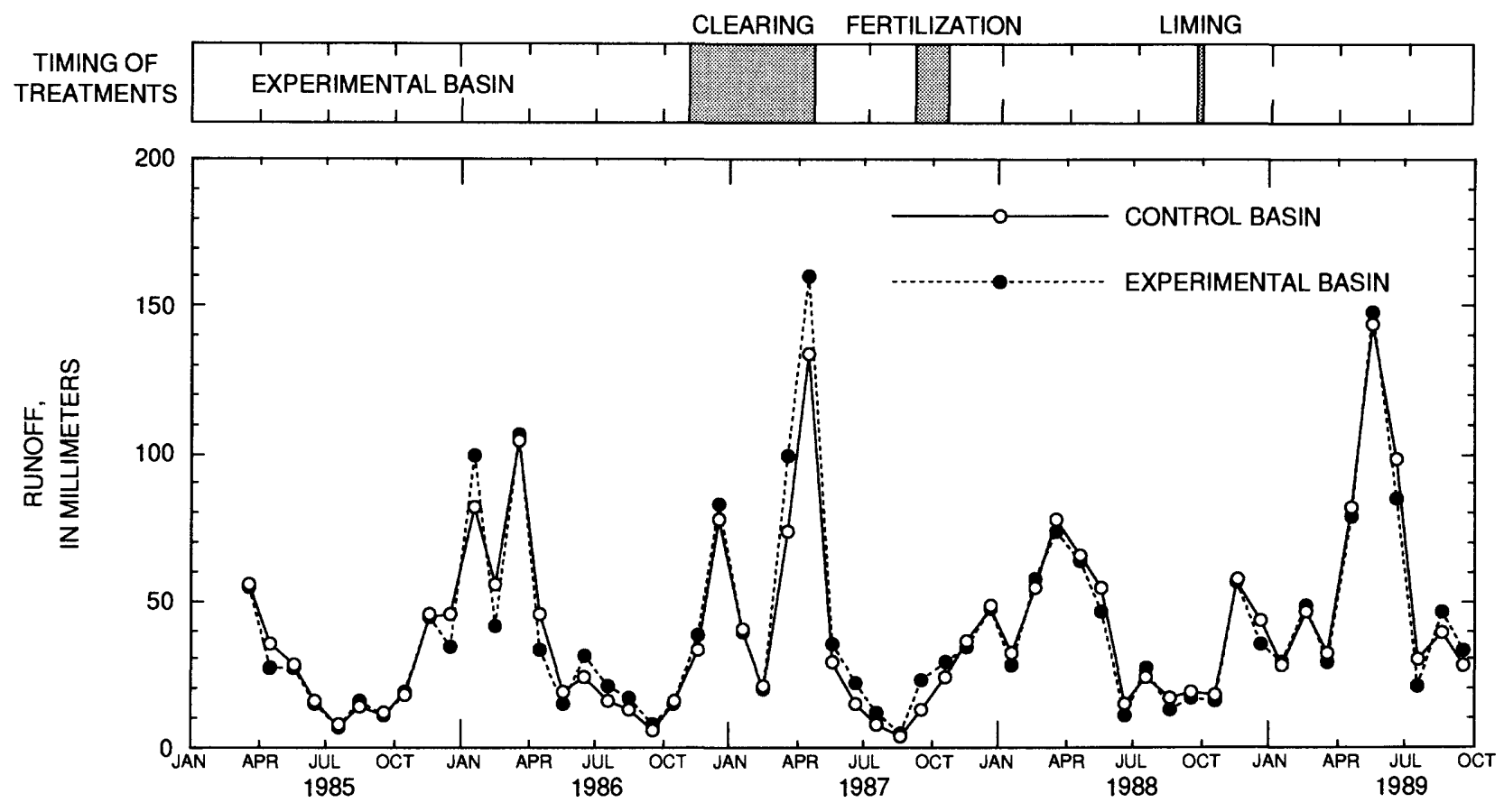

Figure 12. Timing of treatments and monthly runoff from control and experimental basins, Dickey Brook Basin, central Massachusetts, February 1985 through September 1989.

After a basin is cleared, peak flows typically increase because of reduced interception, increased soil compaction, increased soil moisture, and improved delivery efficiency by way of logging road gullies. Increased peak flows following clearing were not observed in the study; the pattern of the flow-duration curves of both basins at high flow was similar in the pre- and posttreatment periods (figs. 6 and 13).

In the middle-flow range, from 20 to 80 percent, the flow-duration curve for the experimental basin was below that of the control basin in the pre-treatment period. In the post-treatment period, both curves were shifted upward, but the curve for the experimental basin was shifted a greater amount such that it nearly coincided with the curve for the control basin. One interpretation of this relative shift is that some water in the experimental basin that would have left the basin as evapotranspiration had the forest not been cleared, left the basin as increased streamflow. The relative enhancement of flow duration in the experimental basin in the middle-flow range could result from higher sustained flows during storm recessions because of reduced evapotranspiration and thus increased soil moisture. However, the upward shift of the flow-duration curve for the control basin indicates that wetter conditions prevailed in the post-treatment period, thus it is difficult to directly compare the two periods.

In the low-flow range, from 80 to 100 percent, flow duration in the experimental basin was sharply reduced relative to the control basin in the post-treatment period. This pattern is opposite to the expectation that the decreased water demand would leave additional water available to sustain base flow. However, lowest flows were measured in both basins during the post-treatment period (figs. 6 and 13). At these low flows, forest clearing in the headwaters probably has little effect on base flow at the outlet. During dry conditions, any increased delivery of water to riparian areas from the cleared uplands would be readily transpired. The divergence in the curves at low flows probably reflects natural differences in the flow characteristics of the two basins under dry conditions. Another consideration is that low-flow measurements are more susceptible to error than high-flow measurements are because of the insensitivity of the stage-discharge relations at natural controls used in this study. 


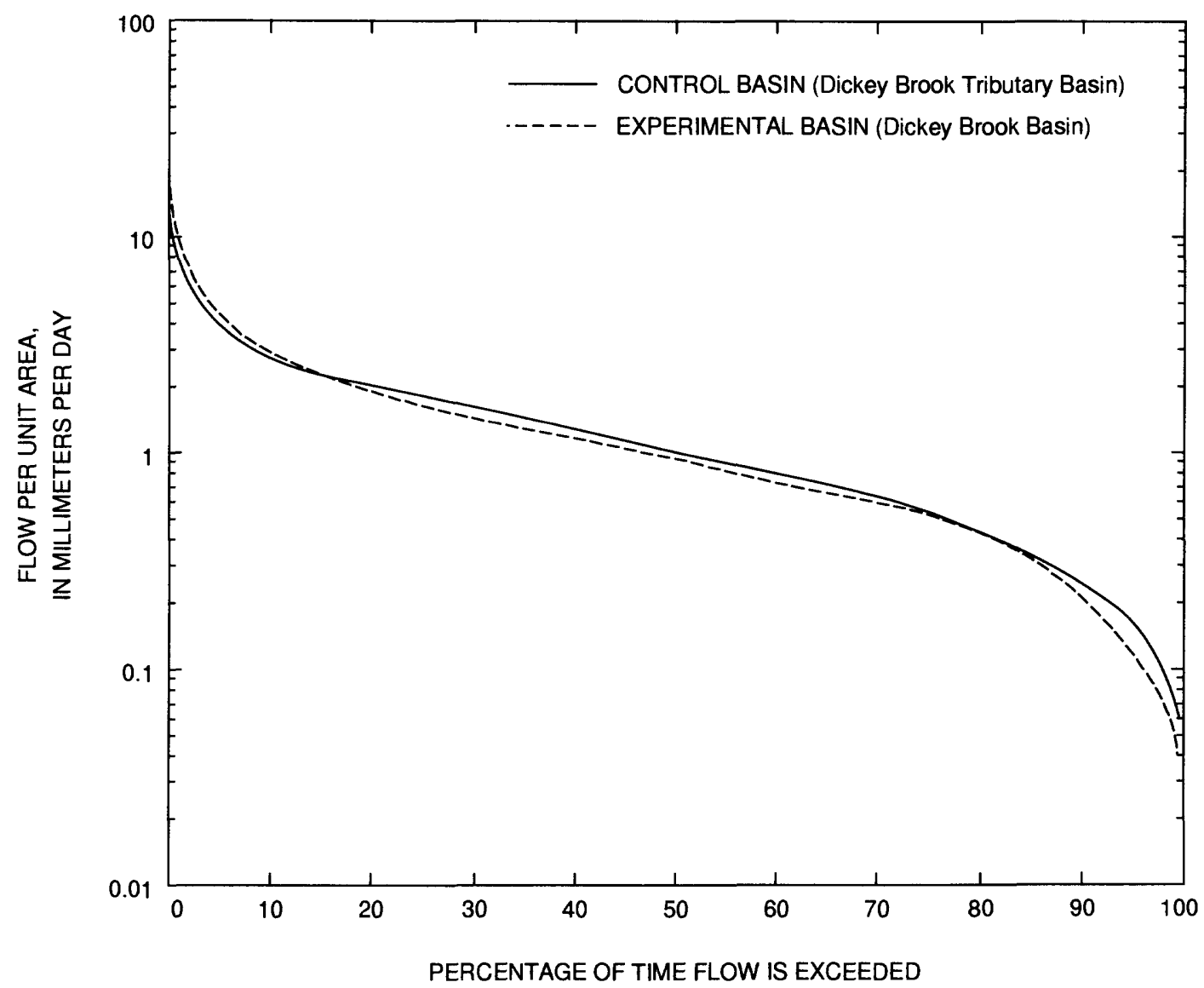

Figure 13. Flow-duration curves for the control and experimental basins, Dickey Brook Basin, central Massachusetts, during the post-treatment period, November 1986 through September 1989.

Paired regressions of pre- and post-treatment logtransformed daily mean streamflows from both basins (fig. 14) indicate a minimal effect of the selective forest clearing on the hydrology. An analysis of covariance (Helsel and Hirsch, 1992) indicates that the slope of the post-treatment regression line was significantly greater than the slope of the pre-treatment regression line, although the difference in slope was slight (table 3). Moreover, the two regression lines intersect, indicating that post-treatment streamflow in the experimental basin increased at high flows but decreased at low flows. The intercepts of the two regression equations were not significantly different. The slope of the post-treatment regression line is strongly affected by low flows. As discussed above, apparent differences in low-flow magnitude and frequency during the post-treatment period are probably unrelated to the forest clearing. The change in slope may be an artifact of insufficient low-flow data during the pre-treatment phase.

The pre-treatment regression equation was used to assess the effect of the forest clearing on water yield. Daily runoff from the control basin during the 


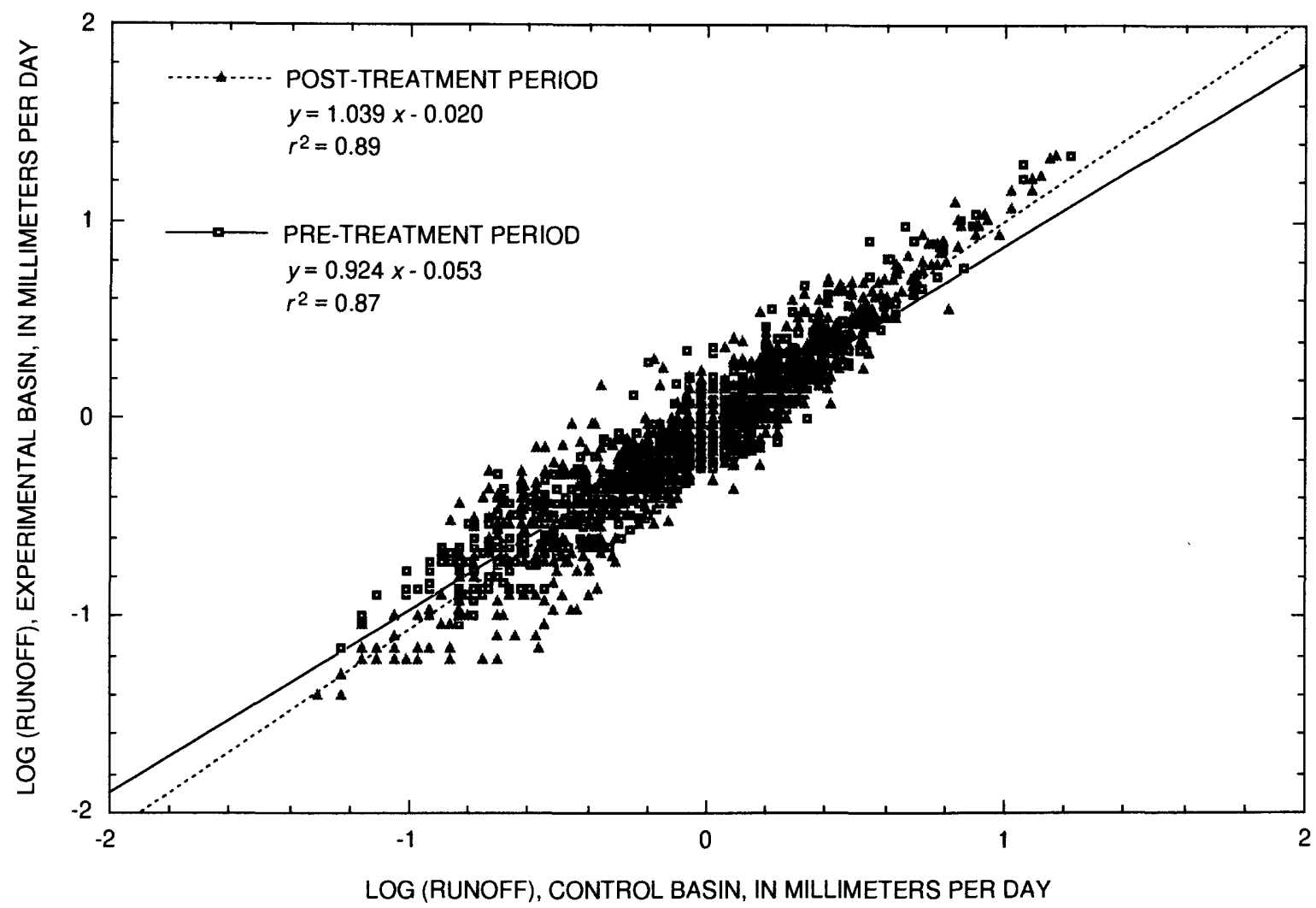

Figure 14. Scatterplots and regression models of daily mean streamflow data from the preand post-treatment periods at the control and experimental basins, Dickey Brook Basin, central Massachusetts. ( $y, \log$ runoff in experimental basin (Dickey Brook Basin); $x, \log$ runoff in control basin (Dickey Brook Tributary Basin); $r^{2}$, coefficient of determination.)

Table 3. Results of pre- and post-treatment regression analysis and analysis of covariance on daily flows at the control and experimental basins near Quabbin Reservoir, central Massachusetts

[Flow in log, millimeter per day. --, not applicable]

\begin{tabular}{lcccc}
\hline \multicolumn{1}{c}{ Regression analysis } & Slope & $y$-Intercept & $\begin{array}{c}\text { Number of } \\
\text { measurements }\end{array}$ & $\begin{array}{c}\text { Coefficient of } \\
\text { determination } \\
\left(r^{2}\right)\end{array}$ \\
\hline Pre-treatment & 0.924 & -0.053 & 615 & 0.87 \\
Post-treatment & 1.039 & -.020 & 1,075 & .89 \\
\hline \multicolumn{1}{c}{ Analysis of covariance } & $T$-value & $p(T)$ & -- & - \\
\hline Test for equal slopes & 6.312 & 0.0000 & -- & - \\
Test for equal $y$-intercepts & 1.233 & .2177 & & - \\
\hline
\end{tabular}


post-treatment period was used as the independent variable in the pre-treatment regression equation (fig. 14) to simulate daily runoff in the experimental basin. The simulated daily streamflow represents the streamflow that would have occurred had there been no clearing. Measured and simulated daily mean flows from the experimental basin during the post-treatment period are presented as flow-duration curves (fig. 15). The measured and simulated flow-duration curves for the experimental basin were similar in the middleflow range. The pre-treatment regression markedly under-simulated flows in the high-flow range (0- to 30 percent flow duration) and over-simulated flows in the low-flow range (85 to 100 -percent flow duration). Although the undersimulation at high flow could be interpreted to represent an increase in water yield as a result of the clearing, note that the pre-treatment regression also undersimulates high flows (fig. 14). Conversely, the divergence of the two curves at low flows may be an artifact of the inadequacy of the regression equation because it is applied to flows in the posttreatment period that were less than flows measured in the pre-treatment period.

Because the effect of the selective tree clearing on the hydrology was not clearly discernible, Bent (1994) specifically reanalyzed the data to detect changes in the hydrologic properties most likely to be affected by the clearing. The data were analyzed for differences in pre- and post-treatment total monthly runoff, instantaneous peak runoff, and daily mean base flow. No increase in runoff as a result of forest clearing was revealed by any of these comparisons.

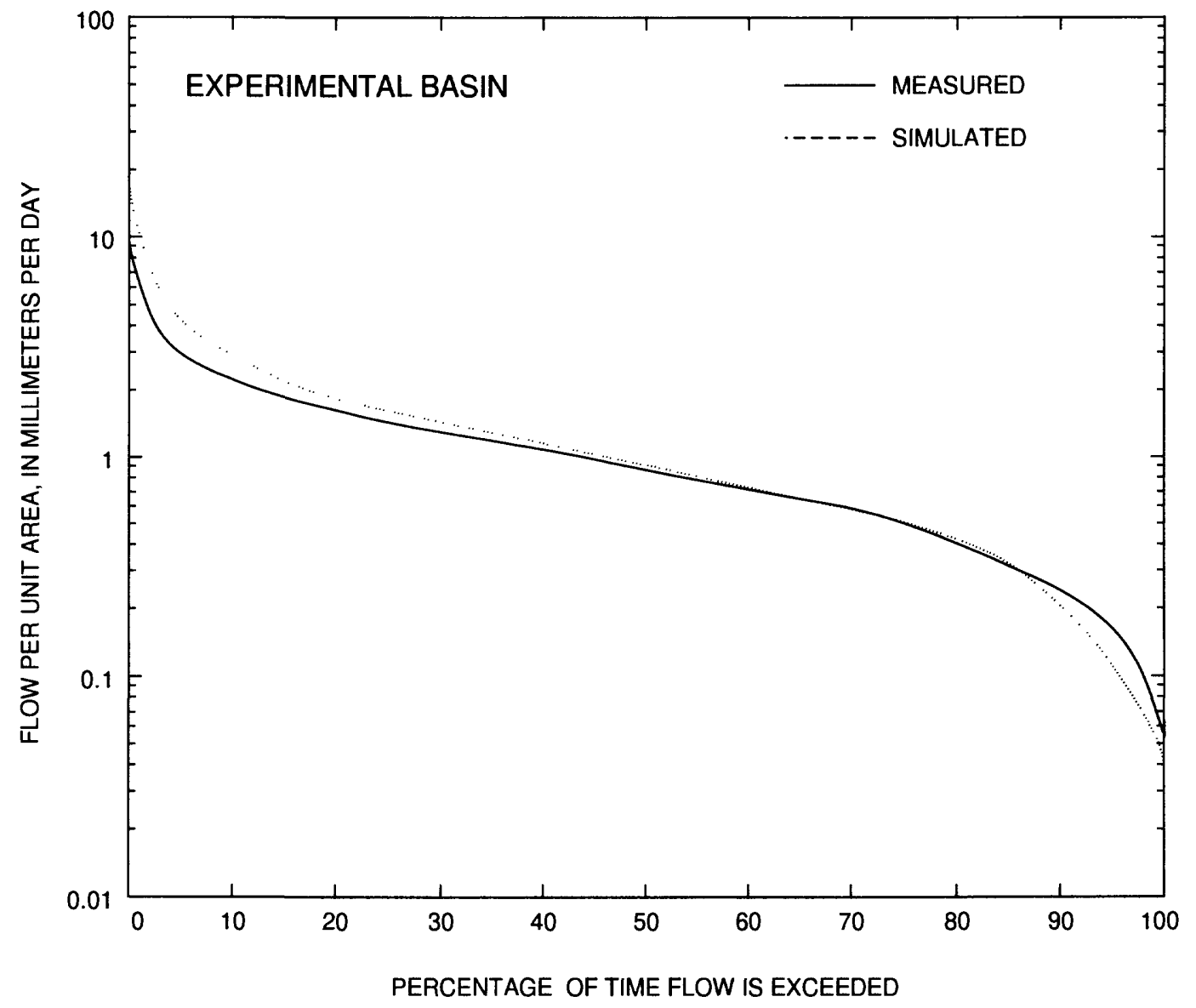

Figure 15. Flow-duration curves for the experimental basin, Dlckey Brook Basin, central Massachusetts, during the post-treatment period (November 1986 through September 1989) computed from measured and simulated daily mean streamflow. 
In summary, forest clearing caused a slight increase in water yield for a few months. Five factors were responsible for the limited response:

1. The area of the cut was limited. Although increases in water yield are generally proportional to the percentage of basal area harvested, results from several studies indicate that a threshold equal to about 25 percent of the basal area must be cut before effects are observed (Hornbeck and others, 1993). In this study, 20 percent of the basal area was removed during the main clearcutting, plus an additional 4 percent from thinning. It irs questionable whether thinning is effective in increasing water yield because the transpiration of remaining trees may increase. Thus, although a slight increase in water yield was observed during the year of the tree clearing, the cleared area was probably too small to cause a lasting effect.

2. The tree clearing was restricted to the headwaters of the basin. The effect on water yield depends on the position of the cleared area within a basin (Hornbeck and others, 1993). Because of the greater availability of water in riparian areas as compared to upland areas, transpiration tends to be greater in riparian forests; thus, clearing of riparian areas has a greater effect on water yield than does clearing of upland areas (Mrazik and others, 1980).

3. The extensive wetlands in the experimental basin are areas of high evapotranspiration. Any additional water that reaches the riparian zone because of increased recharge (or decreased evapotranspiration) upslope may be evaporated or transpired by riparian trees rather than augmenting streamflow. This is particularly true during dry periods.

4. Although precipitation during the entire study period was above average, the year of the selective clearing and the year that followed were relatively dry, particularly during the growing season. Dry conditions are least conducive to generating increased flows after clearing because any excess water that otherwise may have run off as streamflow is used to satisfy evapotranspiration demand.

5. The cleared area was partially revegetated with grasses, which grew in the second year after treatment, and the remaining area was allowed to revegetate naturally. Grass cover has a lower water demand than forest cover, but evapotranspiration losses from grassland are considerable, particularly in the early part of the growing season (Rutter, 1968). Maximum water-yield increases from forest clearing are obtained when revegetation is prevented (Hornbeck and others, 1993).

\section{Changes in Ground-Water Levels}

The effect of the selective forest clearing in the experimental basin on ground-water levels is evident for water year 1987. Water levels of wells NLW16 and NLW17, which were in the area of selective tree clearing, were noticeably higher than usual during the summer, as is evident from comparison with water-level data for the control basin (fig. 16). For water year 1987, the summer decline of the water table at wells in the experimental basin was the smallest of all five summers in the study period, whereas the summer decline at wells in the control basin was the largest of all five summers. This indicates that the clearing caused a significant local decrease in evapotranspiration in the vicinity of the two wells.

\section{Changes in Evapotranspiration}

Monthly estimates of potential evapotranspiration for the experimental and control basins (fig. 17) were derived from monthly mean air temperatures computed from long-term historical data collected at Amherst, Mass. (National Oceanographic and Atmospheric Administration, 1985). The evapotranspiration losses followed the expected seasonal pattern: large losses in the peak of the growing season (approximately May to August) and negligible losses in midwinter. Total monthly evapotranspiration during the growing season ranged from 79 to $132 \mathrm{~mm}$. 

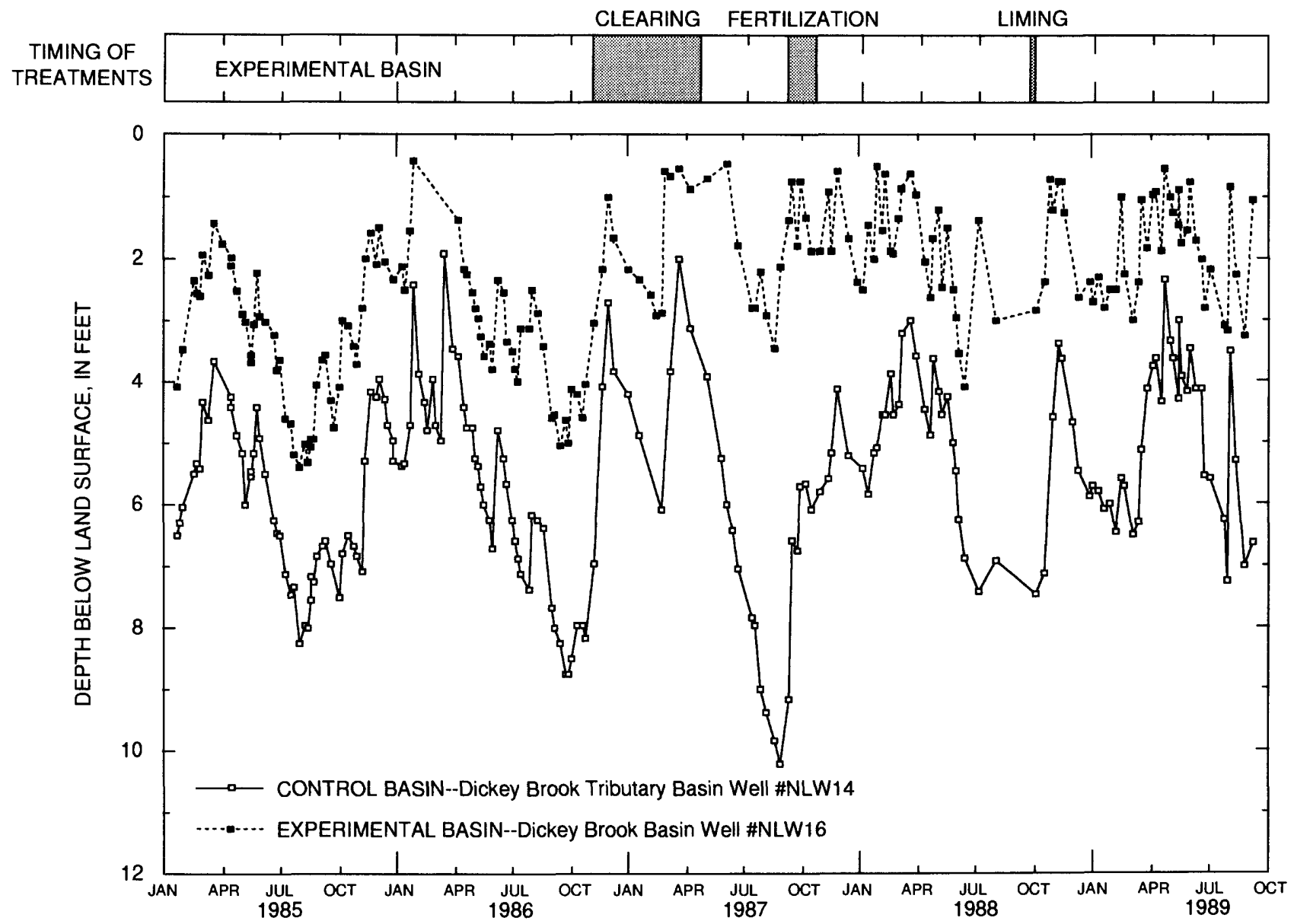

Figure 16. Ground-water levels in wells in the control and experimental basins, Dickey Brook Basin, central Massachusetts, February 1985 through September 1989.

Annual estimates of the decrease in evapotranspiration in the experimental basin during the posttreatment period (table 4) were computed from the regression equation for the pre-treatment daily mean flows. As above, observed post-treatment daily mean flows from the control basin were used as independent data in the pre-treatment regression equation to simulate the daily mean flows that would have occurred in the experimental basin during the post-treatment period had there been no selective clearing. Estimated decreases in evapotranspiration for the post-treatment period in the experimental basin were calculated by subtracting observed from simulated daily mean flows. This approach is based on a simple water budget in which it is assumed that either no loss of ground water from the basin or a constant rate of loss. The daily differences were summed to compute the annual differences. The greatest decrease in evapotranspiration was during water year 1987, which coincides with the year of the selective clearing. The decrease in evapotranspiration for water years 1988 and 1989 was not as great as it was in water year 1987, most likely because of the return of vegetation in the cleared areas. 


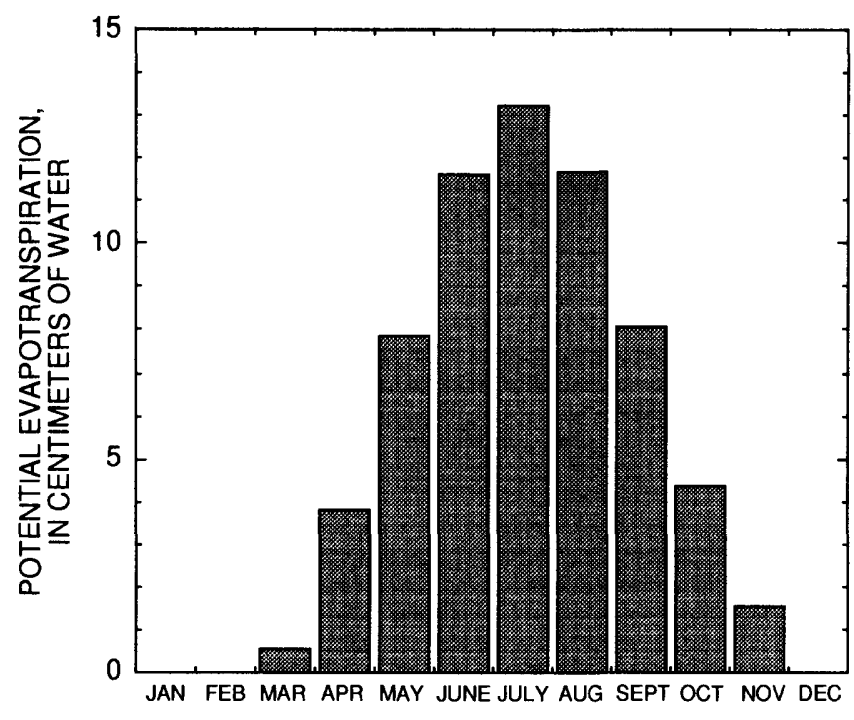

Figure 17. Estimated monthly potential evapotranspiration for the study area, Dickey Brook Basin, central Massachusetts.

Table 4. Estimated annual decrease in evapotranspiration as a result of selective forest clearing in the experimental basin. Dickey Brook Basin. central Massachusetts

\begin{tabular}{cc}
\hline Water year & $\begin{array}{c}\text { Estimated annual decrease } \\
\text { in evapotranspiration, } \\
\text { in millimeters }\end{array}$ \\
\hline 1987 & 16.26 \\
1988 & 4.27 \\
1989 & 8.76 \\
\hline
\end{tabular}

\section{EFFECTS OF SELECTIVE FOREST CLEARING, FERTILIZATION, AND LIMING ON WATER QUALITY}

\section{Changes in Solute Fluxes}

Temporal patterns of solute concentrations in the two basins were consistently similar throughout the study period (fig. 18). This similarity indicates that no fundamental shifts or trends in water quality resulted from selective forest clearing and conversion of cleared areas to grass cover. It is especially noteworthy that the applications of fertilizer in October 1987 and lime in September 1988 had minimal effect on solute concentrations in streamwater. Applications of potassium, nitrogen, calcium, and alkalinity in the form of fertilizer and lime in the experimental basin constituted very large pulse inputs of these solutes (table 5), in some cases larger than the entire annual input from precipitation. At most, any trends and episodic rises in solute concentration that may be related to the forest clearing and treatments are minimal.

Solute-concentration models were developed to assess effects of selective forest clearing, fertilization, and liming on solute fluxes. The object of applying a solute-concentration model is to use data that are readily available - information such as streamflow (or some transformation thereof), day of year, length of antecedent dry period - as independent variables to simulate solute concentrations, for which measurements are relatively infrequent. For the control basin, solute-concentration models were developed from chemical data from the entire $4 \frac{1}{2}$-year study period. For the experimental basin, separate models were developed for each solute for the pre-treatment and posttreatment periods. The post-treatment period in the experimental basin was marked by a series of disturbances, including the two periods of forest clearing activity and the pulse inputs of fertilizer at the beginning of the second water year and lime at the beginning of the third water year. Nevertheless, no systematic increases, decreases, or related spikes in solute concentrations were evident as a result of these disturbances, so a single model for each solute in the post-treatment period was adequate. Solute-concentration models for the post-treatment period generally had higher $r^{2}$ (that is, a higher percentage of the variation in solute concentrations was explained by the model parameters) than those of the pre-treatment period. The parameters and coefficients used in each model formulation are summarized in table 6 . 

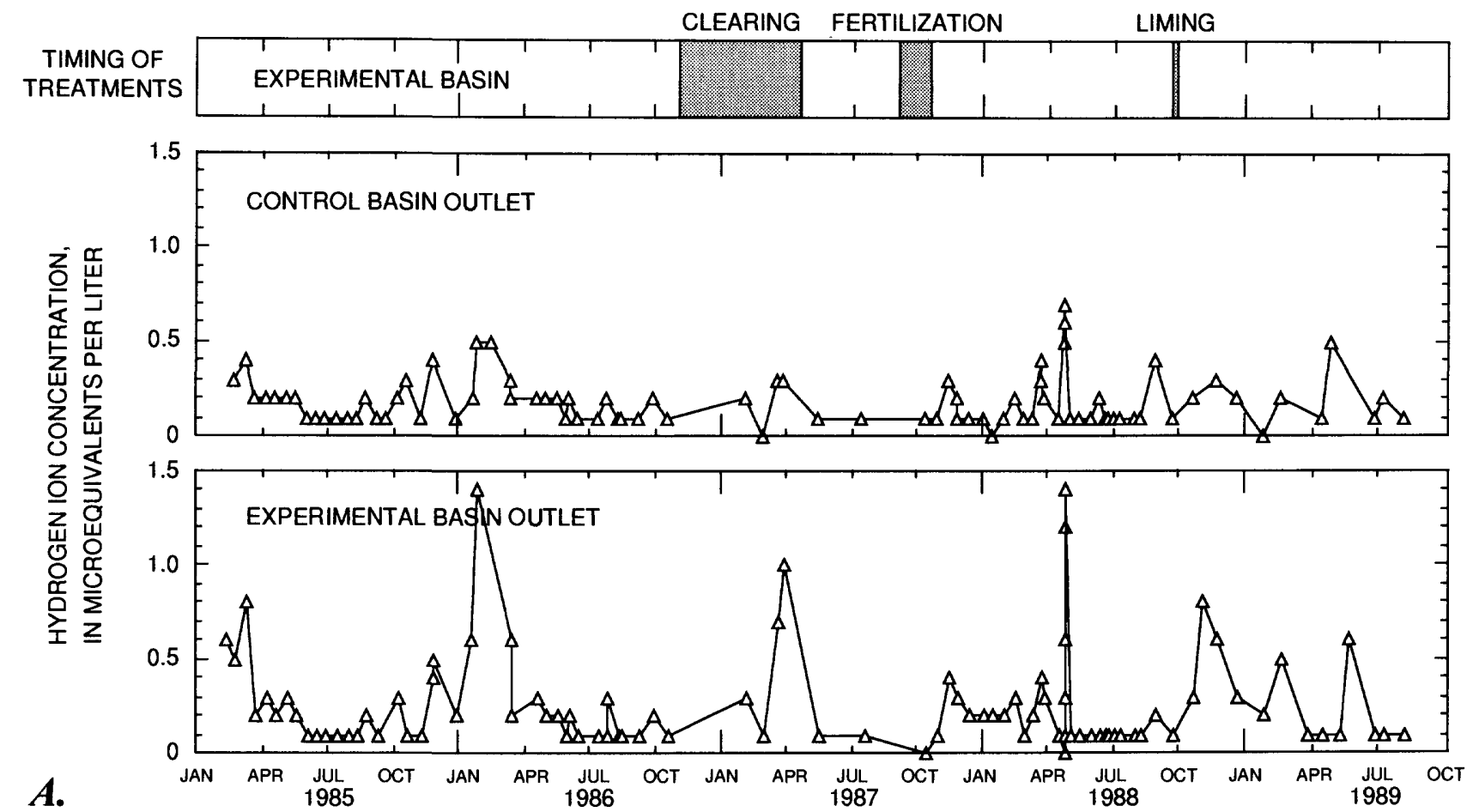

A.

A.
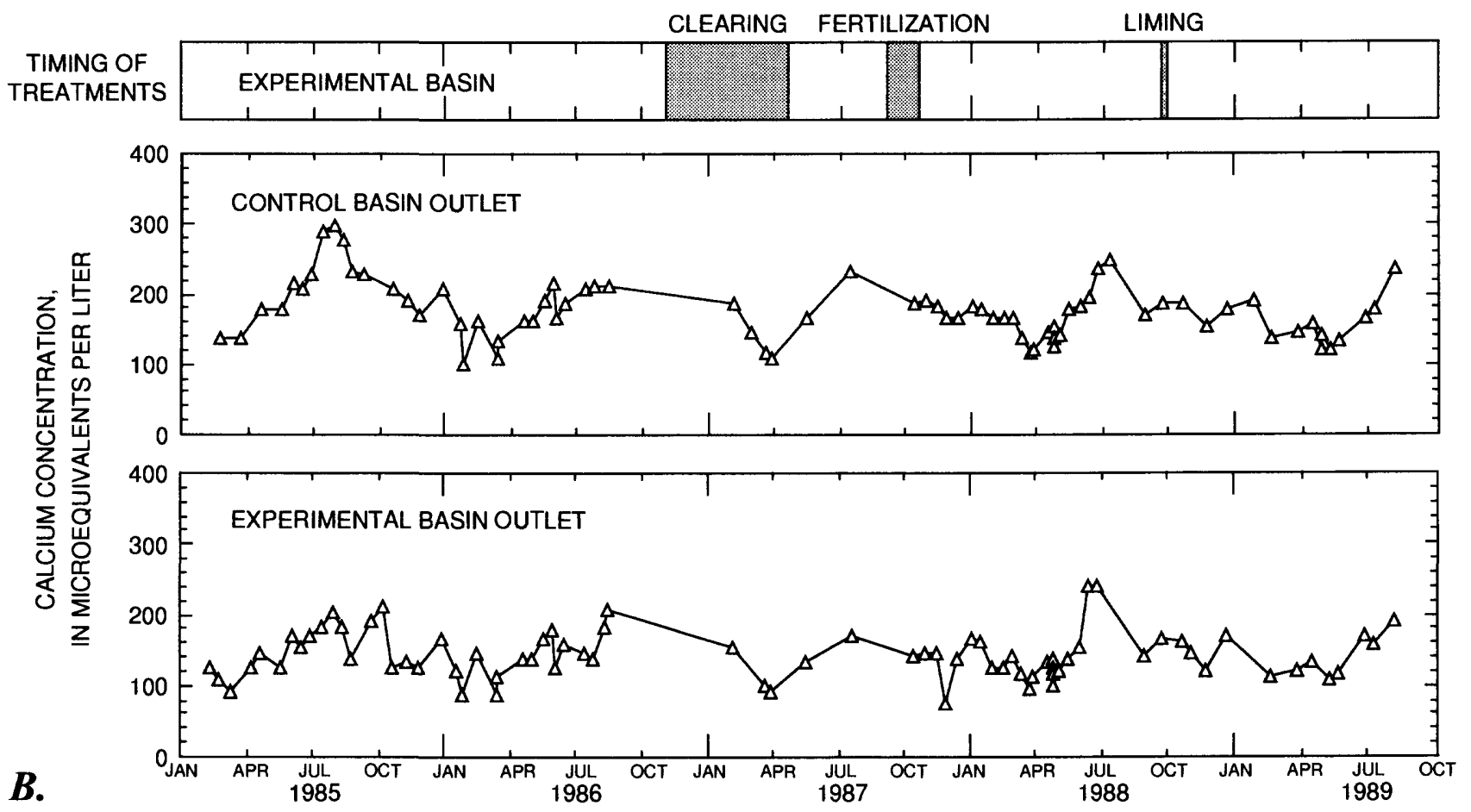

Figure 18. Solute concentrations in stream water at the control- and experimental-basin outlets, Dickey Brook Basin, central Massachusetts, February 1985 through September 1989. 

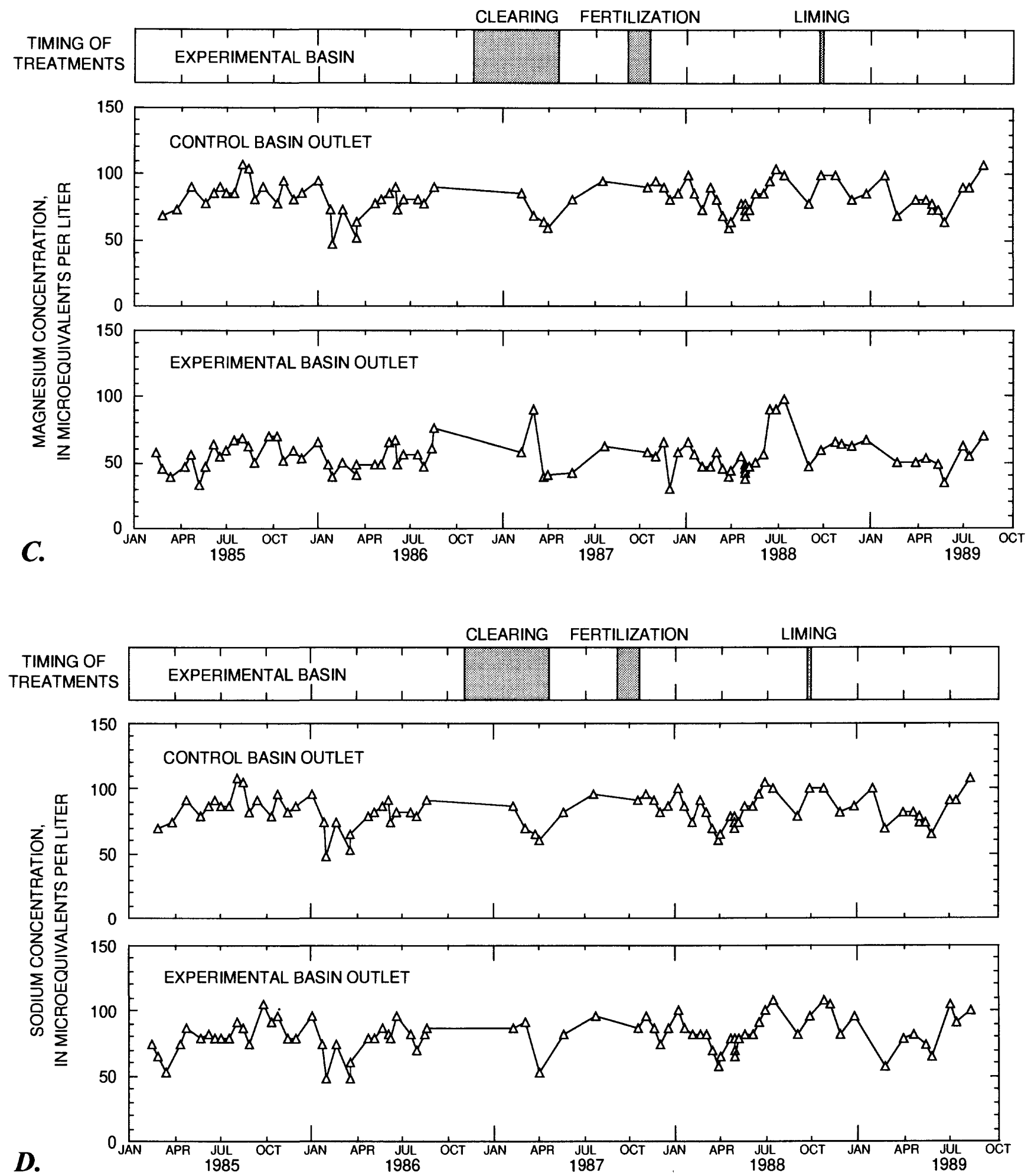

Figure 18.-Continued. 

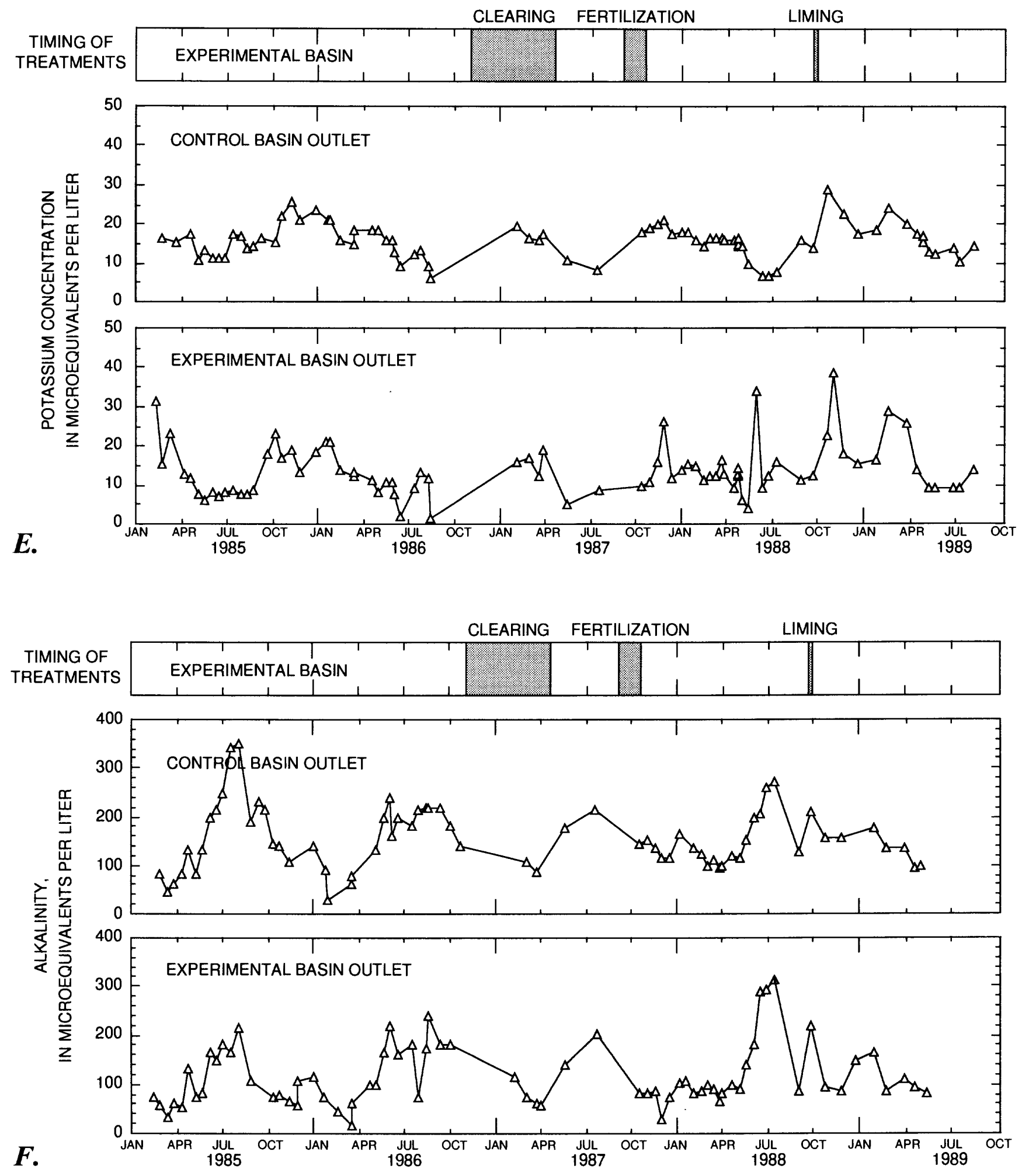

Figure 18.-Continued. 

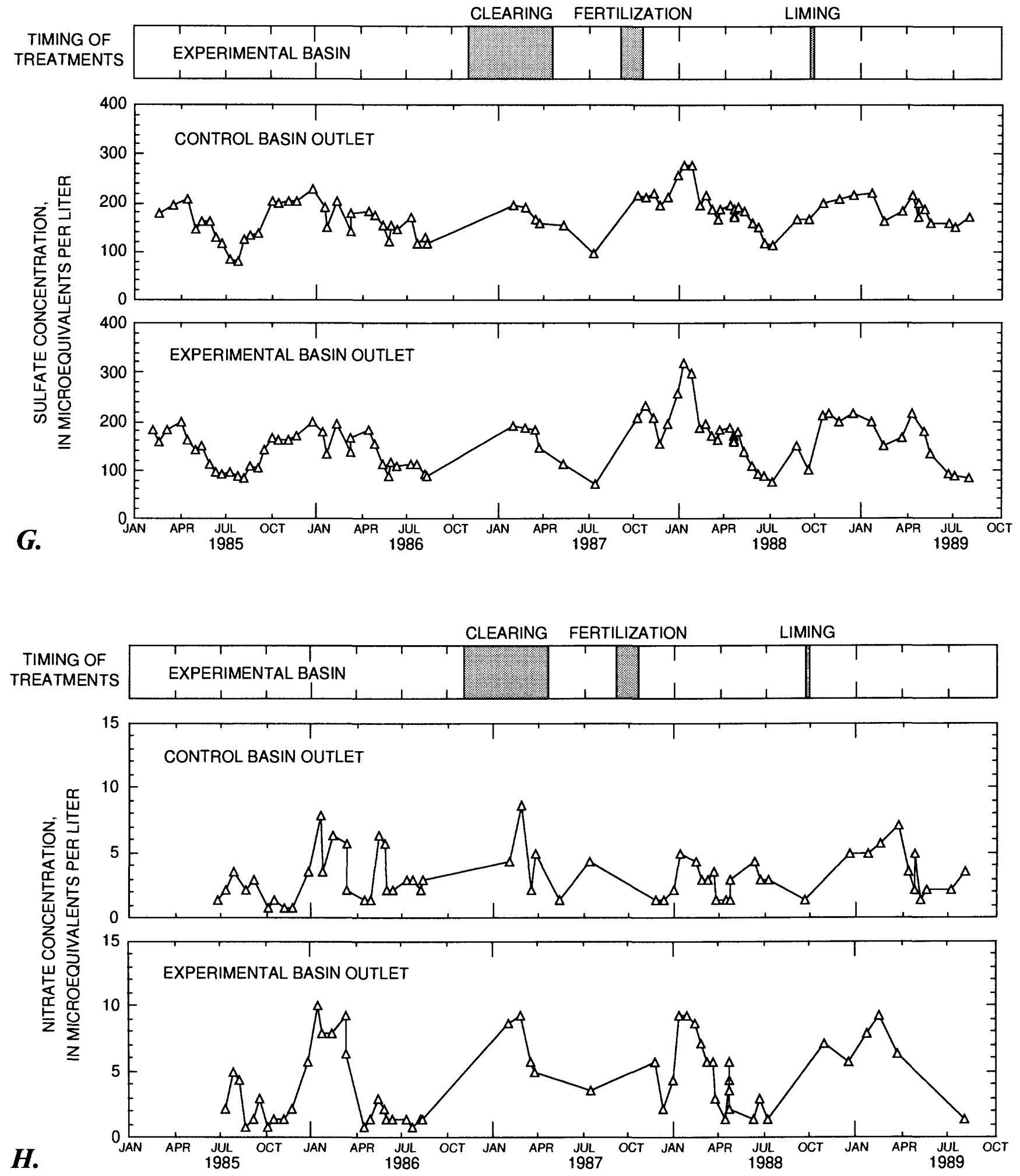

Figure 18.-Continued. 

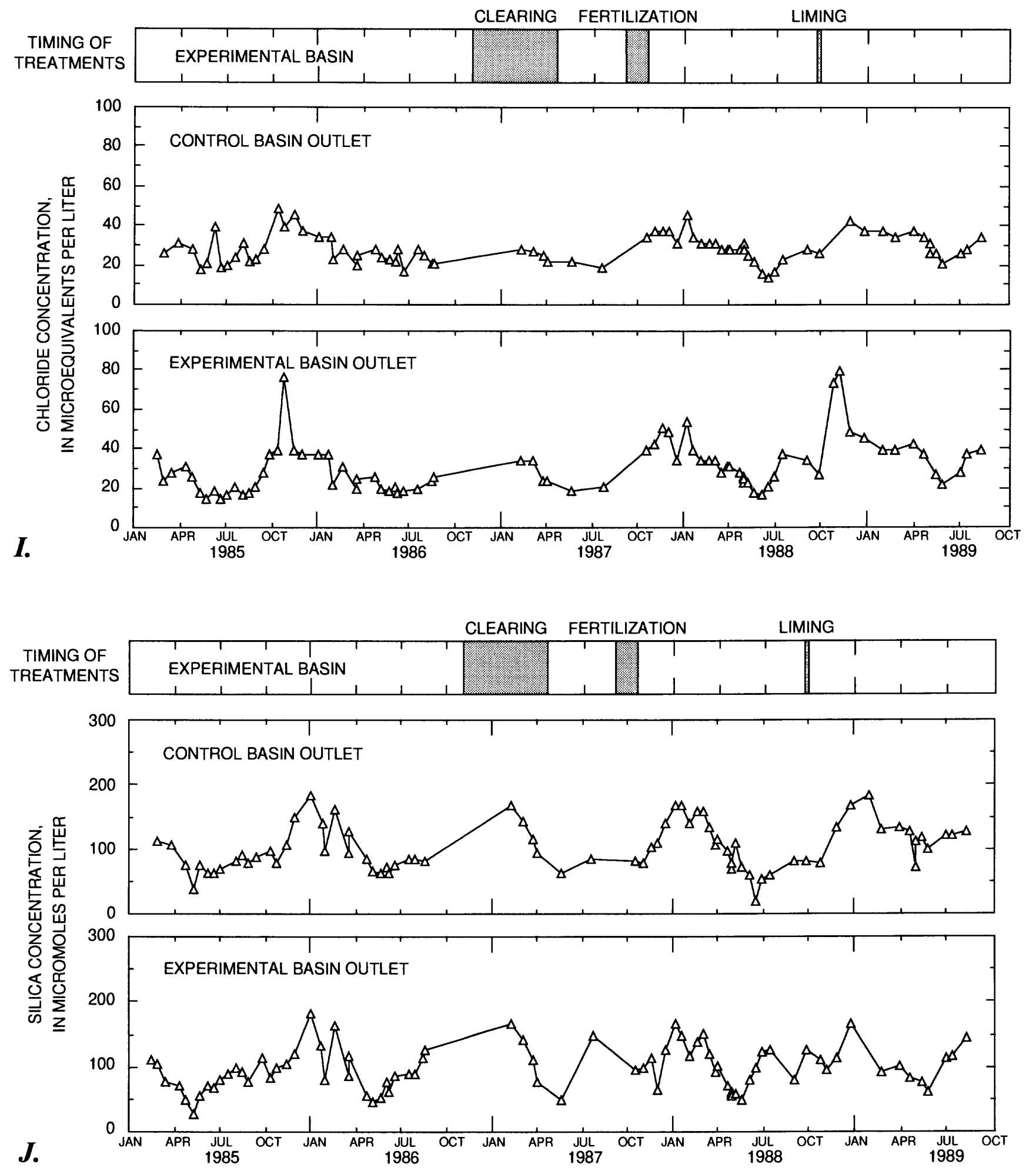

Figure 18.-Continued. 

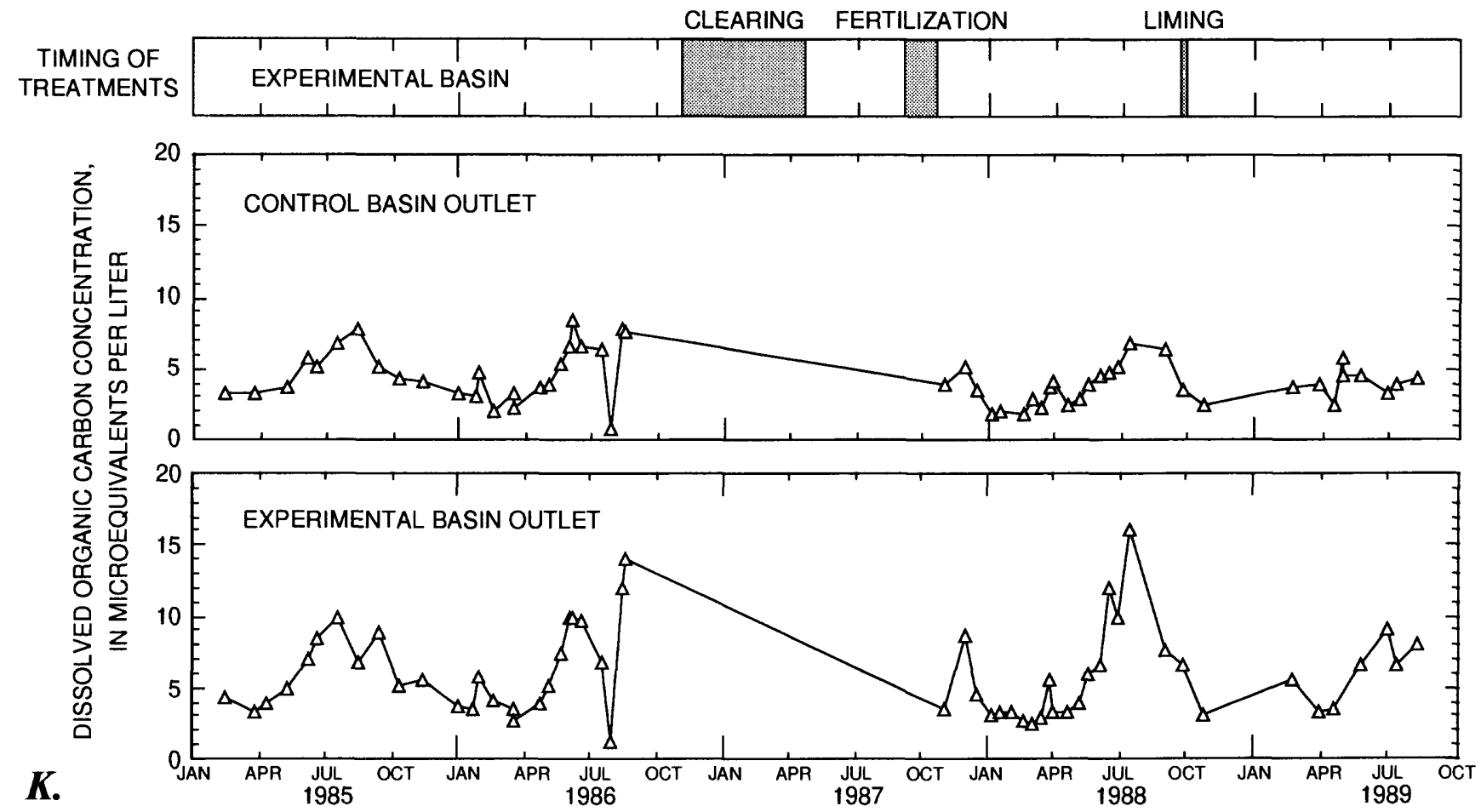

Figure 18.-Continued.

Table 5. Fertilizer and lime inputs to experimental basin, normalized to basin area. Dickey Brook Basin, central Massachusetts

[Quantity in equivalents per hectare]

\begin{tabular}{lclc}
\hline Source & $\begin{array}{c}\text { Date of } \\
\text { application }\end{array}$ & \multicolumn{1}{c}{ Constituent } & Quantity \\
\hline Fertilizer & September 1987 & Nitrogen (N) & 65.52 \\
& & Phosphorus (P) & 19.56 \\
\multirow{2}{*}{ Lime } & Potassium (K) & 9.74 \\
& September 1988 & Calcium (Ca) & 2,231 \\
& & Bicarbonate $\left(\mathrm{HCO}_{3}\right)$ & 2,231 \\
\hline
\end{tabular}




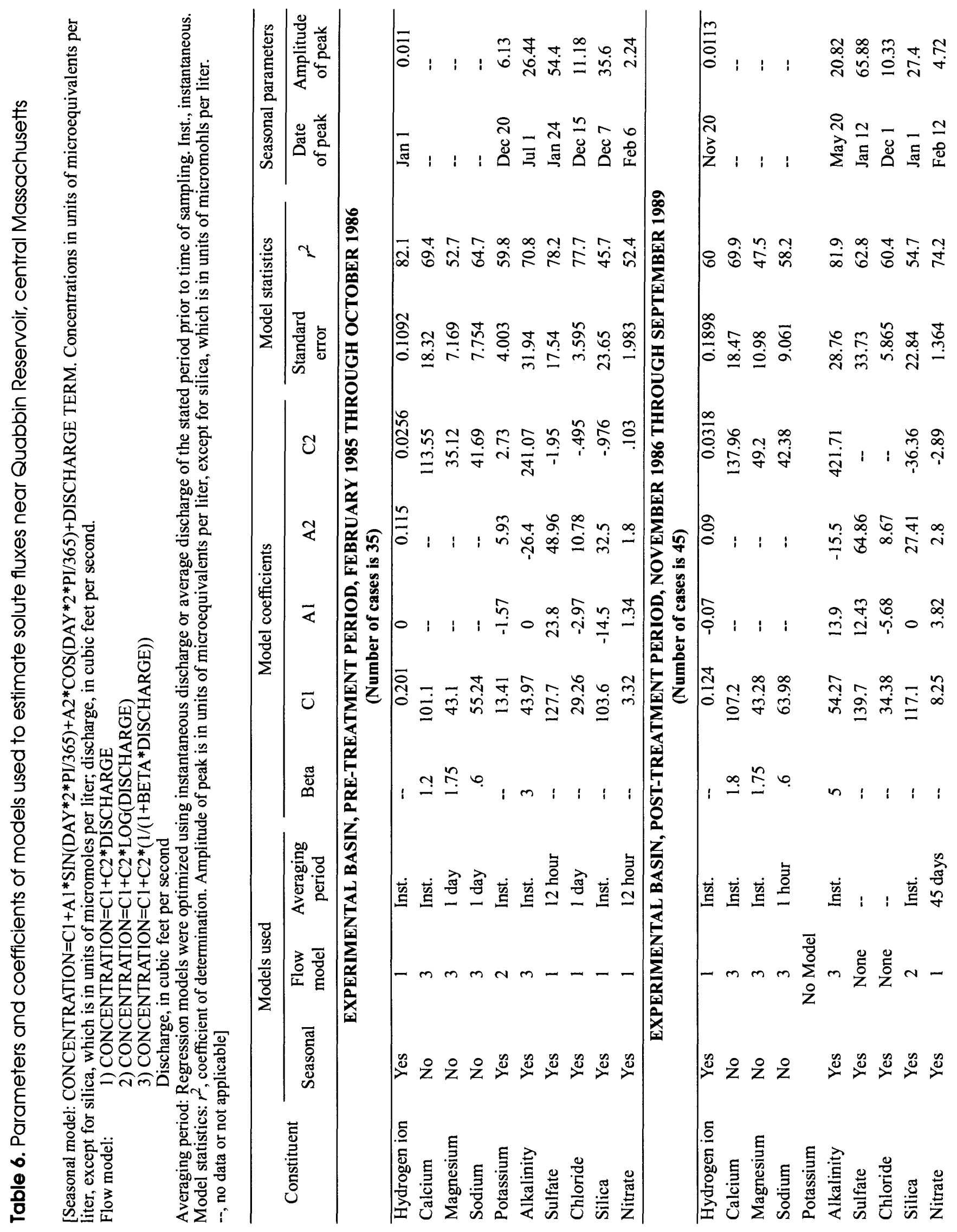




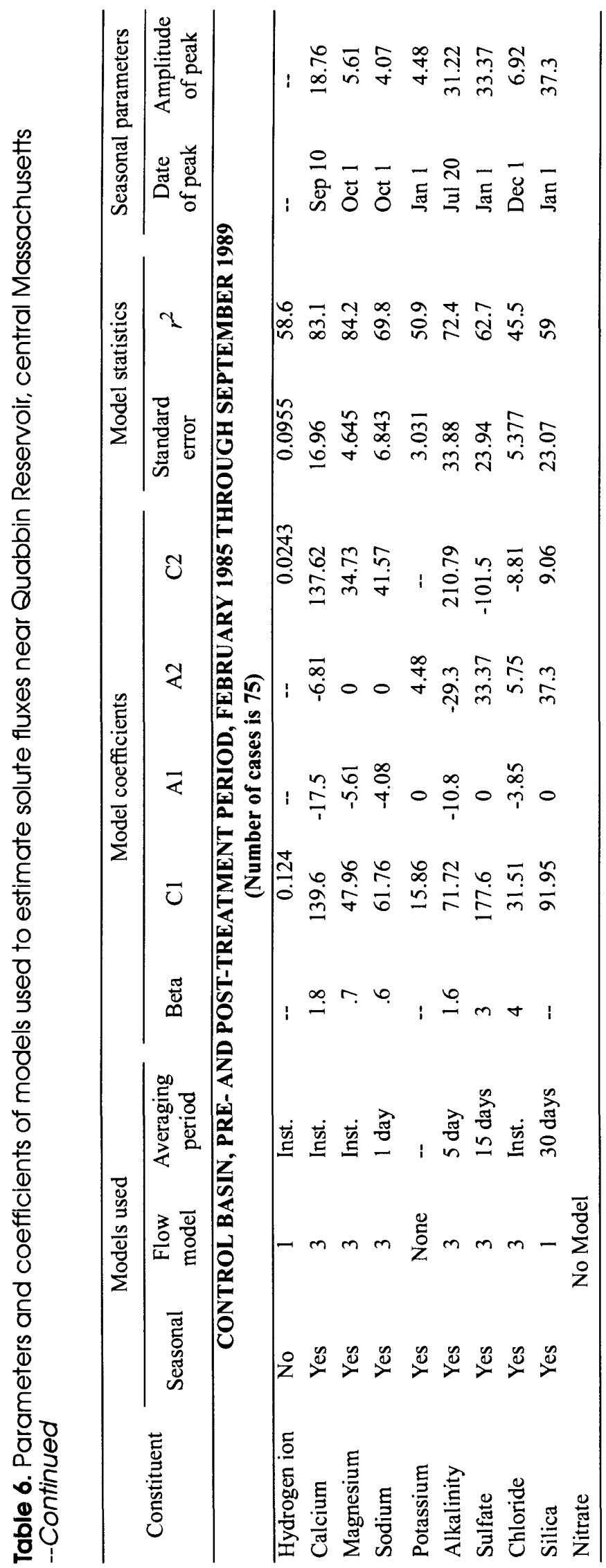


Five generalizations can be made from a comparison of annual fluxes of all solutes in both basins (fig. 19):

1. Chemical loads in precipitation in each basin were nearly identical. The minor differences in input loads for a solute generally were inconsequential relative to the higher loads in streamwater for most solutes. Thus, a single input value was used in each of the bar graphs for annual flux.

2. Annual solute output fluxes were similar between basins during each year of the study, despite the disturbances in the experimental basin.

3. In water year 1989, output fluxes in both basins were markedly higher than in any other water year during the study, because of generally wetter conditions in that year.

4. Solute fluxes in streamwater in the control basin were slightly higher than solute outputs in the experimental basin, following the differences in concentration mentioned above.

5. Solute fluxes increased in the experimental basin relative to those in the control basin in water year 1987, the year in which most of the forest clearing took place. However, these relative increases were almost directly proportional to the increase in water yield (fig. 11).

The similarity of temporal variations among solute fluxes is a logical consequence of the linkage between solute flux and water flux. This correspondence is apparent in the similarity between the monthly runoff (fig. 12) and the monthly solute fluxes (fig. 20). The higher annual solute fluxes in the experimental basin relative to the control basin in water year 1987 were attributed predominantly to higher water yield in that year. In particular, higher flows in March and April accounted for most of the increase in solute flux at the experimental basin in water year 1987. The major differences in the model structure used to determine the chemographs for specific solutes indicate that various combinations of seasonal and hydrologic characteristics control solute flux. However, the strong correlation between chemical flux and water flux indicates that water flux is the overriding control on solute flux from the basins. Thus, the concentrations of most solutes did not change as a result of the forest clearing.

If the concentration of a solute does not change but water yield increases, the increase in solute flux will be directly proportional to the increase in water yield. The changes in solute flux resulting from the forest clearing independent of changes in water yield were evaluated by normalizing annual solute fluxes (fig. 18) to annual runoff (fig. 11). Next, the ratio of runoff-normalized annual solute fluxes in the experimental basin to runoffnormalized annual solute fluxes in the control basin was computed for each year of the study (table 7). Variations in this ratio from year to year for a given solute indicate that some factor other than water yield affected solute flux.

Runoff-normalized annual flux ratios (table 7) for calcium, sodium, potassium, and sulfate were relatively constant from year to year. Fluxes of these solutes were most closely linked to water yield. Magnesium, nitrate, and silica fluxes appeared to have been affected by the clearing in 1987, but each of these solutes also had a similar change in the ratio in 1989 , which was the wettest year of the study. Compared to the other years of the study, normalized ratios in water years 1987 and 1989 were higher for magnesium (by 5-10 percent), and lower for nitrate (by 30-40 percent) and silica (by 12-15 percent). Because 1987 and 1989 were the 2 years of greatest water yield in the experimental basin, the similar ratios of these solutes in these two years could be linked either to biogeochemical effects of the clearing that are manifested under wet conditions or simply to changes in basin hydrochemistry at higher flows. Alkalinity flux in 1987 increased by approximately 10 percent more than that expected from water flux alone, but no similar effect was observed in 1989. 

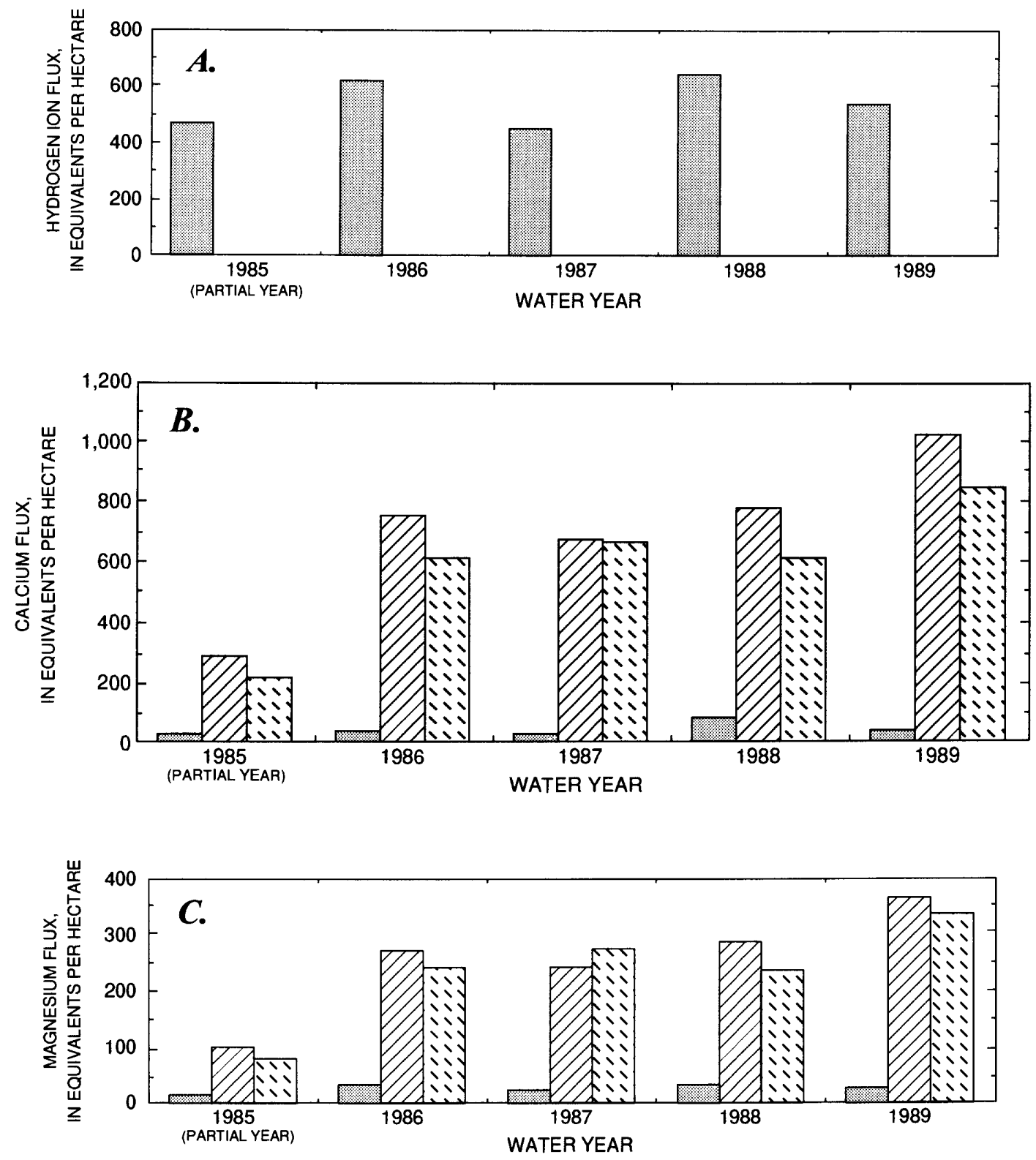

EXPLANATION

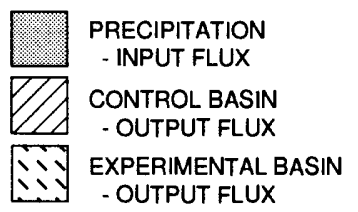

Figure 19. Annual input and output fluxes at the control and experimental outlets, Dickey Brook Basin, central Massachusetts, water years 1985 through 1989 (data for water year 1985 are from February through September only). 

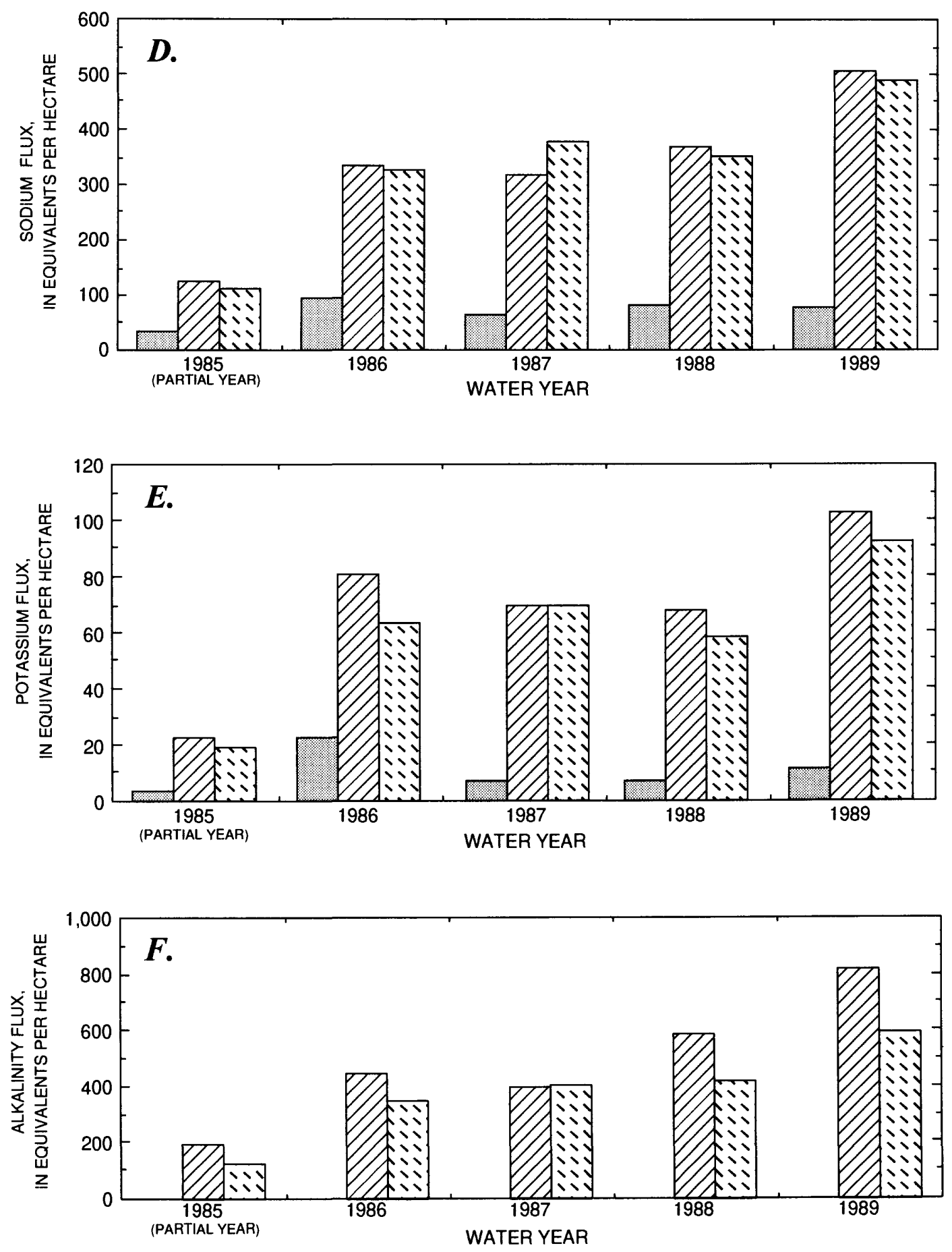

Figure 19.-Continued. 

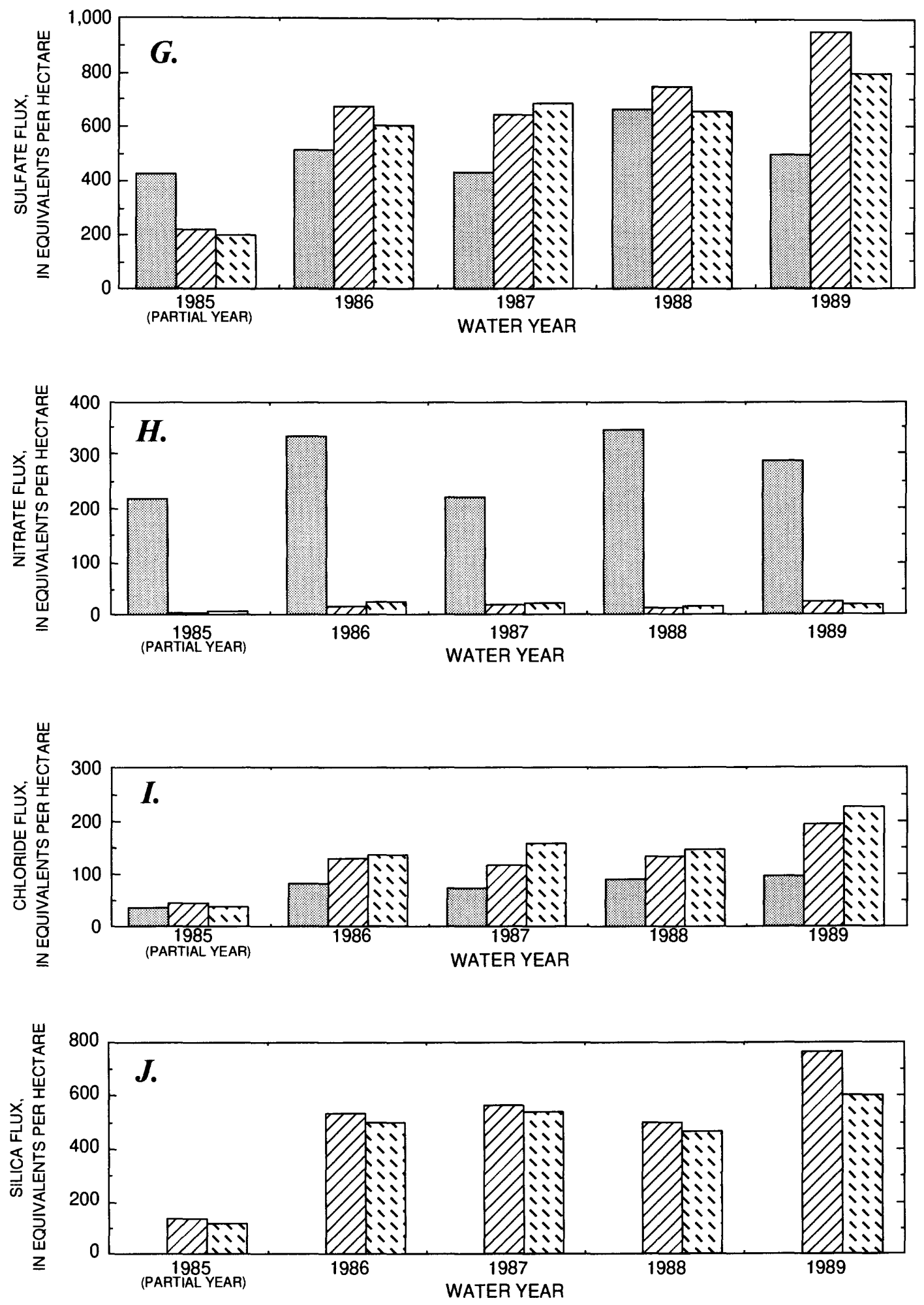

Figure 19.-Continued. 


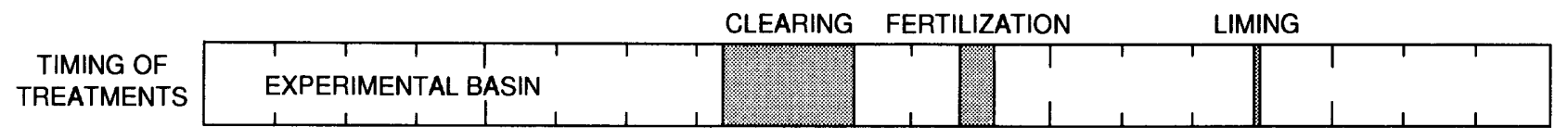

$\boldsymbol{A}$.
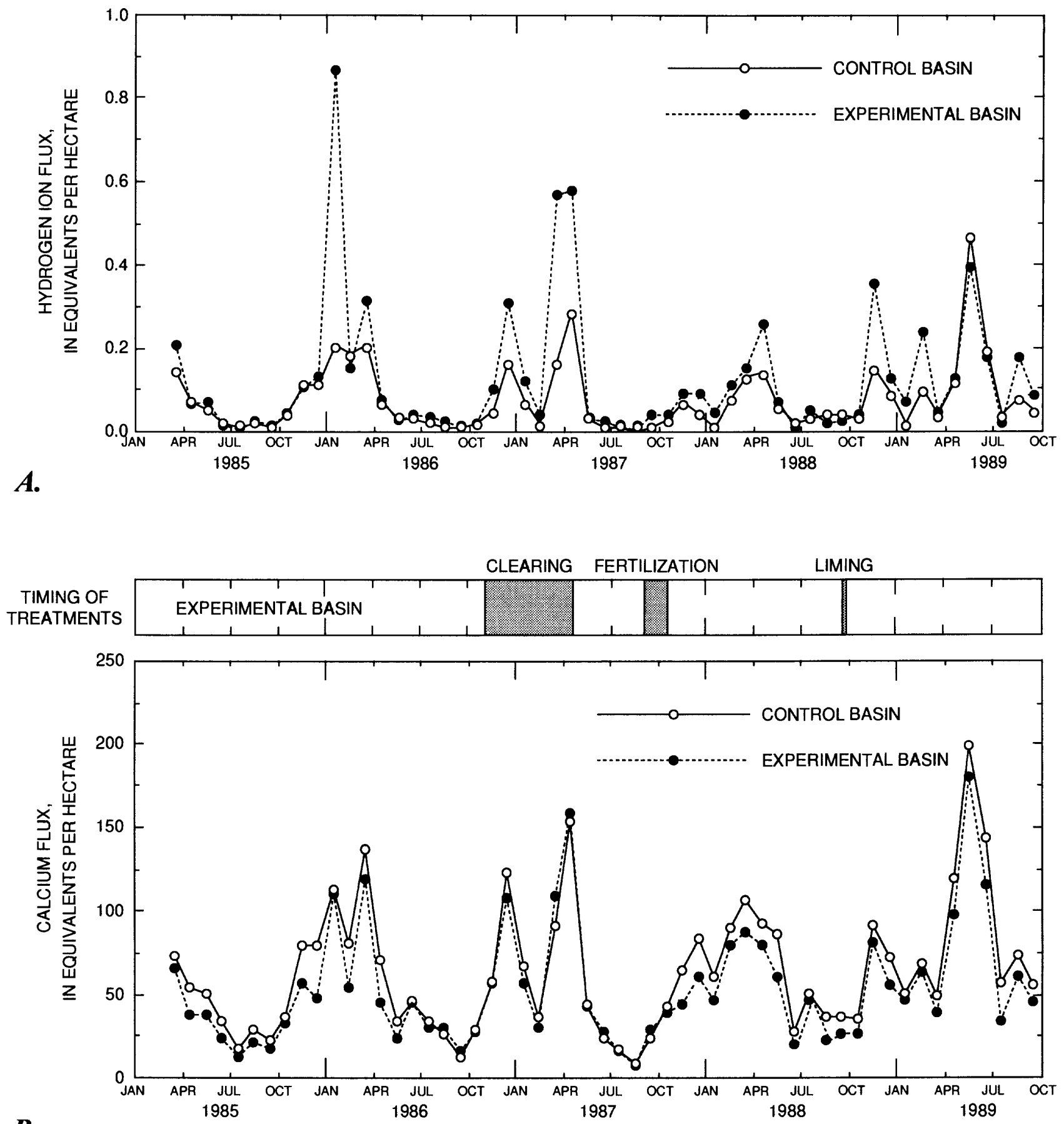

B.

Figure 20. Timing of treatments in experimental basin and monthly solute fluxes in streamwater at the control- and experimental-basin outlets, Dickey Brook Basin, central Massachusetts, February 1985 through September 1989. 

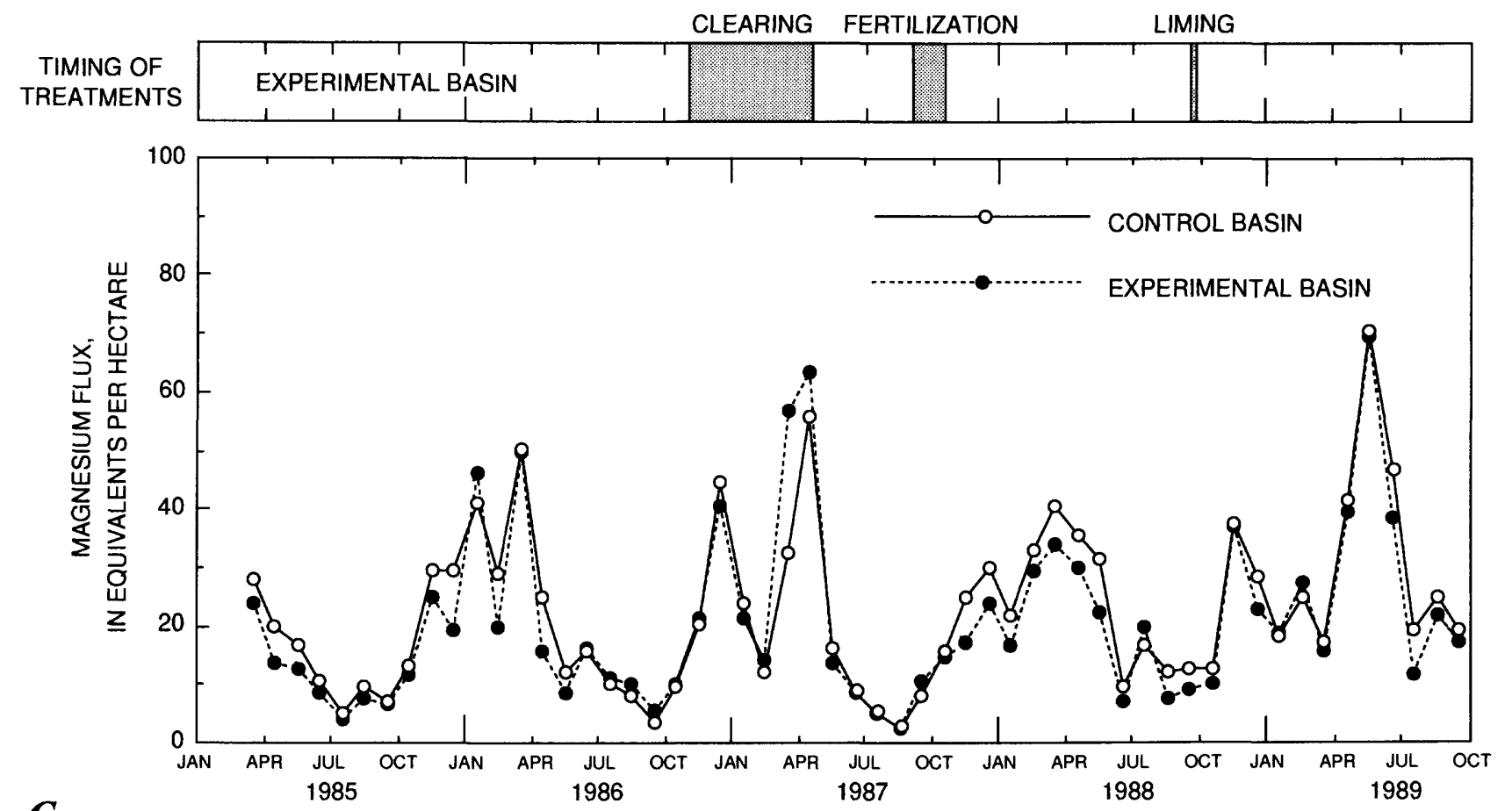

C.
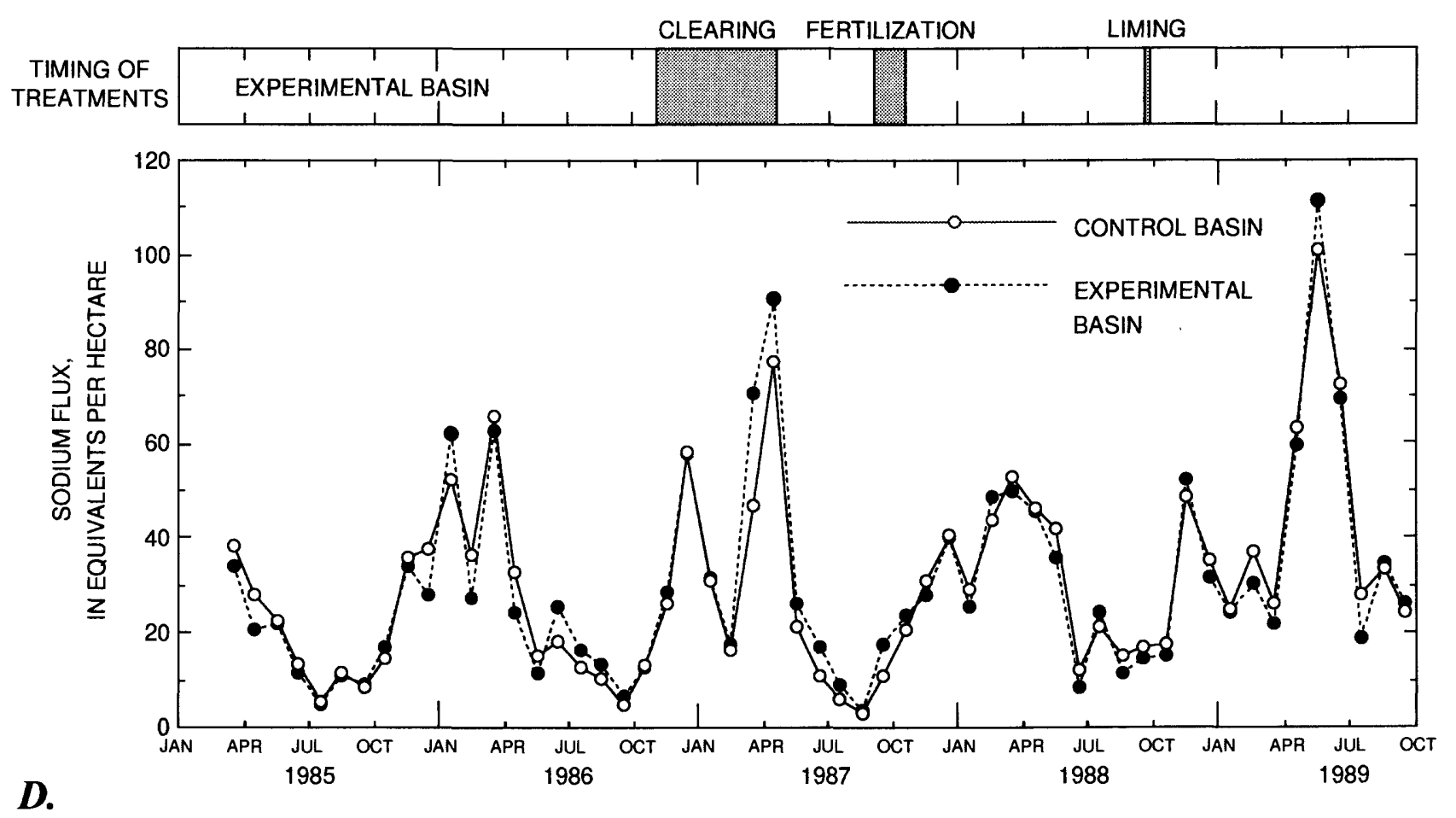

Figure 20.-Continued. 


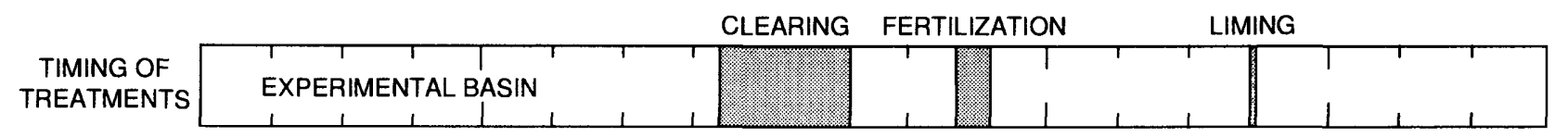

E.
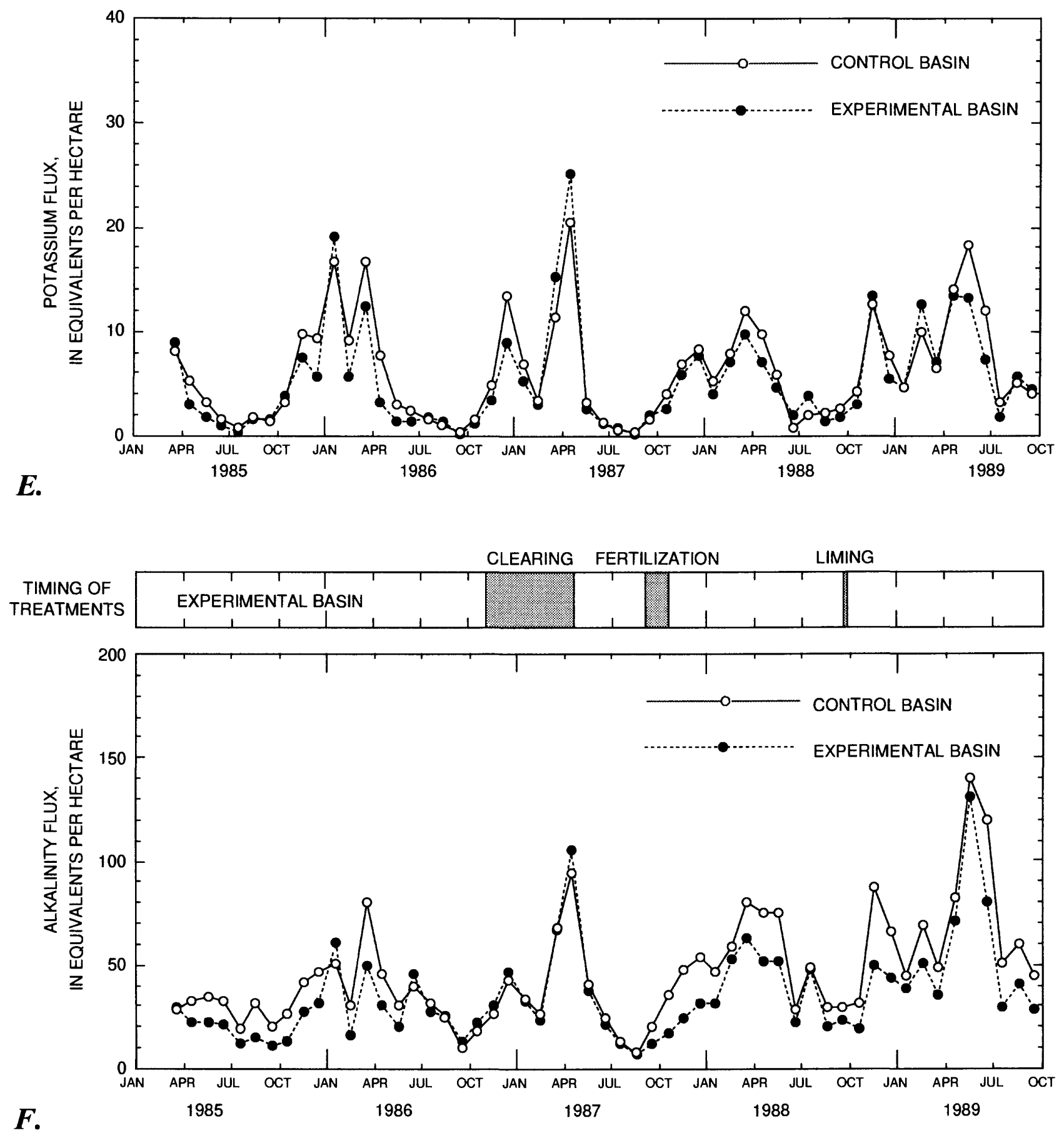

Figure 20.-Continued. 


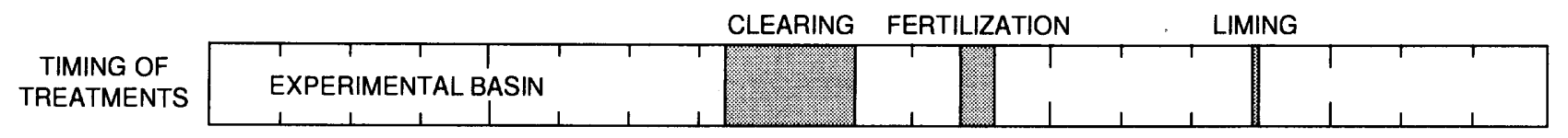

G.
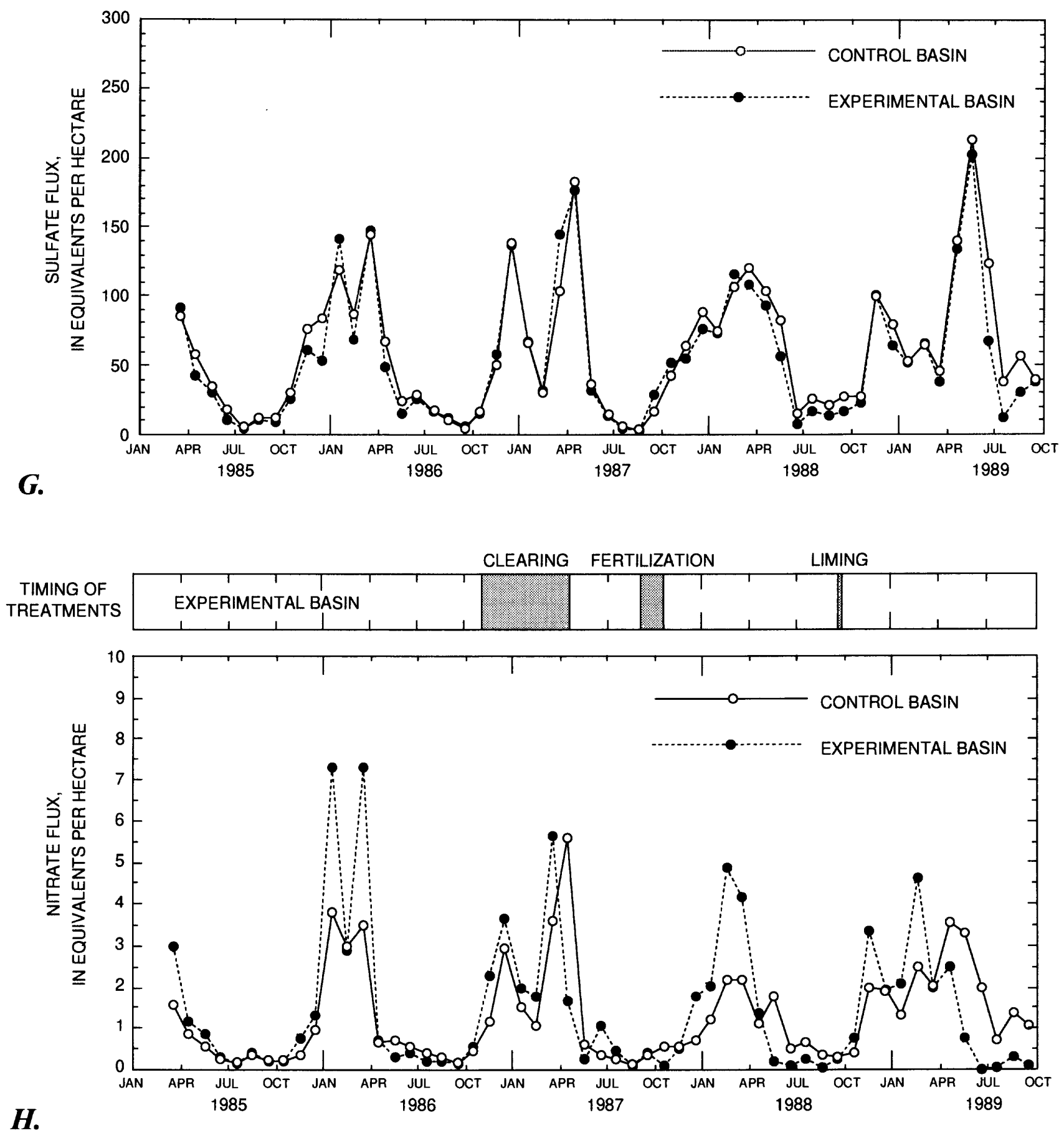

Figure 20.-Continued. 


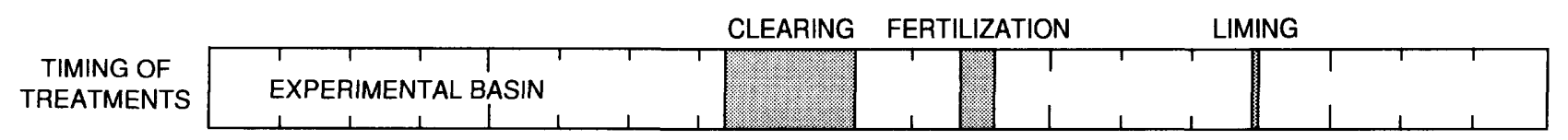

I.
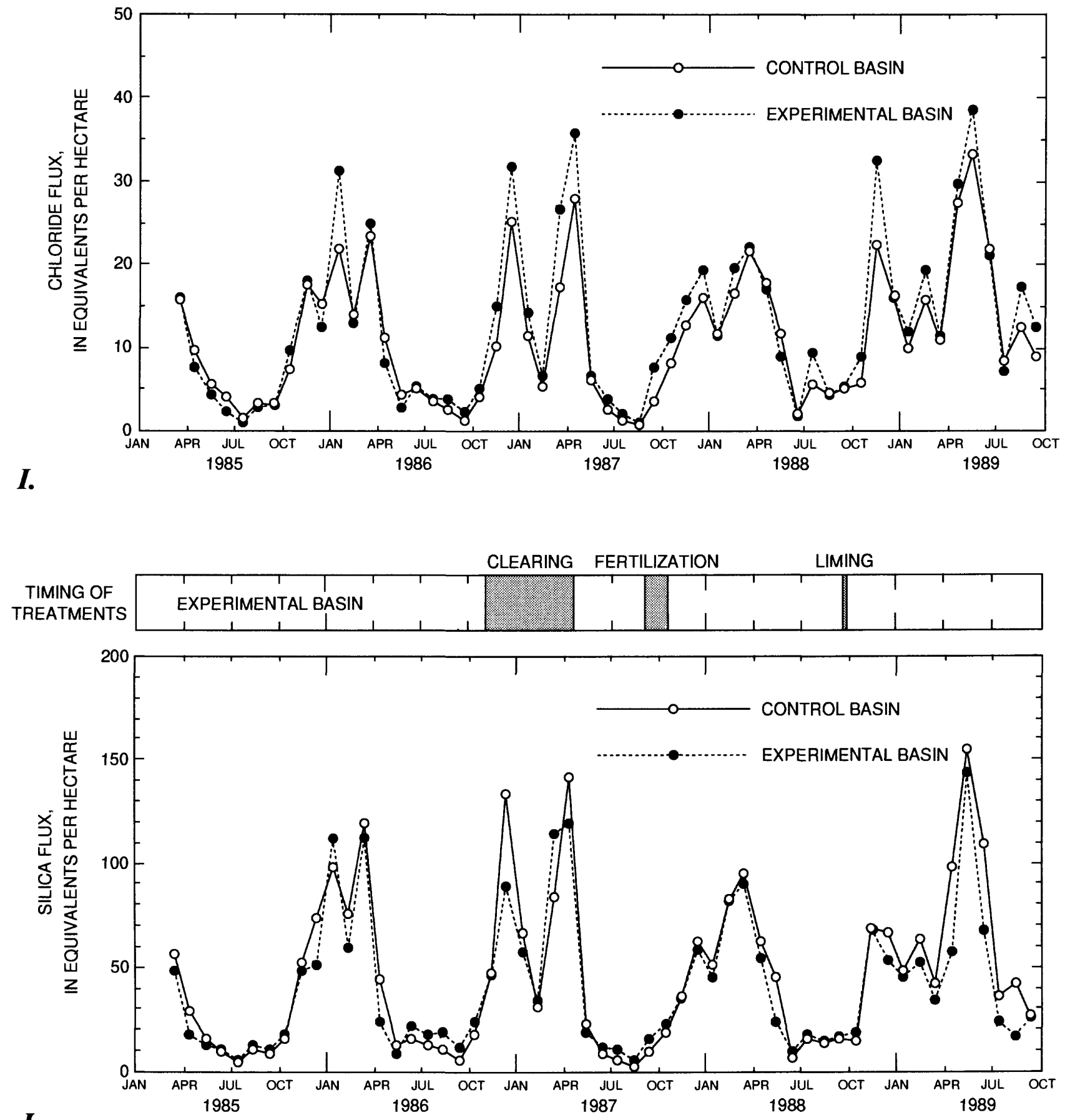

J.

Figure 20.-Continued. 
Table 7. Ratios of runoff-normalized annual solute fluxes in the experimental basin to runoff-normalized annual solute fluxes in the control basin, Dickey Brook Basin, central Massachusetts

[Water year 1985, data from February through September only]

\begin{tabular}{rcrrrrrrrrr}
\hline $\begin{array}{c}\text { Water } \\
\text { year }\end{array}$ & $\begin{array}{c}\text { Hydrogen } \\
\text { ion }\end{array}$ & Calcium & Magnesium & Sodium & Potassium & Alkalinity & $\begin{array}{c}\text { Sulfate, } \\
\text { dissolved }\end{array}$ & Chloride & Silica & Nitrate \\
\hline 1985 & 1.42 & 0.80 & 0.84 & 0.94 & 0.87 & 0.71 & 0.94 & 0.91 & 0.92 & 1.67 \\
1986 & 1.77 & .81 & .89 & .97 & .79 & .78 & .90 & 1.07 & .94 & 1.50 \\
1987 & 1.79 & .83 & .93 & .99 & .83 & .84 & .89 & 1.13 & .80 & .92 \\
1988 & 1.47 & .82 & .85 & 1.00 & .89 & .75 & .92 & 1.15 & .98 & 1.32 \\
1989 & 1.38 & .86 & .94 & 1.00 & .93 & .75 & .87 & 1.21 & .81 & .86 \\
\hline
\end{tabular}

The changes noted above are small compared to the large effects documented in other studies, which generally involved a greater percentage of cleared area. For example, Martin and Pierce (1980) found that nitrate concentrations increased by more than a factor of 10 after clearcutting. In the present study, nitrate concentrations actually decreased after selective clearing. The small annual fluctuations in solute flux observed at the experimental basin are probably within the range of natural variations; no definitive changes can be related to forest clearing, fertilization, and liming.

Forest clearing has the potential to release nutrients to streamflow. Hornbeck and others (1986) summarized the mechanisms by which nutrient release occurs as (1) decomposition of remaining dead tree material, enhanced by increased temperature and light (see also Patric and Reinhart, 1971), (2) decreased nutrient uptake by vegetation, (3) increased nitrification; that is, conversion of organic nitrogen to nitrate as organic matter mineralizes, and (4) increased weathering and cation leaching associated with the acidifying effect of nitrification (see also Lawrence and others, 1987). Acidification of soil after forest clearing also has the effect of increasing sulfate adsorption, so sulfate concentrations in streams may decrease (Nodvin and others, 1986). All of these changes reverse rapidly - within a few years-if the cleared area is allowed to regenerate; a young canopy has a high nutrient demand (Bormann and Likens, 1979).

Despite the expectation of increased nutrient flux, several other studies have found little change in streamwater chemistry as a result of forest clearing. Martin and others (1984) examined 6 totally cleared and 32 partially cleared basins in New England. For most basins, and particularly for those that were not completely clearcut, changes in stream chemistry were within the range of natural variations among streams. Likewise, Corbett and others (1978) and Aubertin and Patric (1974) found only minimal effects on stream chemistry from cleared basins in other areas of the eastern United States. Somewhat greater effects were observed at Hubbard Brook, N.H., where some of the most comprehensive studies have been done. Significant increases in nitrate, calcium, and potassium were observed within the first 3 years after clearcutting at Hubbard Brook (Pierce and others, 1972; Hornbeck and others, 1975; Martin and Pierce, 1980).

The relative lack of change in streamwater chemistry after forest clearing in the experimental basin is consistent with the other studies mentioned above where the basins were not completely clearcut. The lack of response of the nutrients calcium and potassium indicates that any of these nutrients that may have been released by decomposition were either sequestered by the new-grown grass, or stored in the soil because runoff was insufficient to transport them to the stream. An acidification effect (Nodvin and others, 1986; Lawrence and others, 1987) also seems not to be a likely cause; alkalinity was the lone solute that increased (relative to the increase in water yield) in the year of the clearing only (table 7). The increase in alkalinity is consistent with the decrease in nitrate in that year. Nitrate is generally more readily affected by forest clearing than other solutes, and the effect is invariably an increase in flux due to nitrification (Martin and Pierce, 1980; Vitousek, 1981; Lawrence and others, 1987). The 
observed decrease in nitrate (relative to water flux), particularly in light of further additions in the form of fertilizer in late 1987, underscores the lack of effect on stream chemistry from the selected forest clearing at the experimental basin.

The only apparent effect on chemical fluxes from the forest clearing is associated with increased water flux in the first year of the clearing, as seen by comparing monthly hydrologic flux (fig. 12) and monthly solute fluxes (fig. 20) in the control and experimental basins. The pattern in monthly fluxes for calcium (fig. 20B) typifies the pattern for most constituents. In each month from the first full month of data collection in March 1985 through May 1986, and again in each month from October 1987 until the end of the study in September 1989, output flux of calcium was higher at the control basin than that at the experimental basin, generally by more than 10 percent. During water year 1987 , however, monthly calcium fluxes in the two basins were nearly equivalent. Although this change in pattern started before the forest clearing, more significance is given to the anomalously high calcium flux in the experimental basin beginning during the spring 1987 runoff and extending through summer 1987. In March and April 1987, calcium flux in the experimental basin substantially exceeded that in the control basin. The timing and magnitude of this relative increase in calcium flux is in phase with the relative increase in water flux at the experimental basin.

The effect appeared to end abruptly in October 1987. After this time, the pattern of greater calcium flux in the control basin was reestablished; calcium flux in the control basin exceeded that in the experimental basin by 30 percent in water year 1988 and 23 percent in water year 1989. These percentages underscore the absence of any observed effect of the lime application in September 1988. Clearly, liming had a negligible effect on streamwater chemistry at the outlet of the basin during the first year after application.

Magnesium flux (fig. 20C) followed a pattern similar to calcium flux, except for a more substantial spike in magnesium flux in the experimental basin in March 1987. Sodium flux (fig. 20D) also increased sharply in March 1987, but, in general, the monthly sodium fluxes in the two basins followed a similar pattern more than did calcium and magnesium fluxes. Potassium flux (fig. 20E) was less predictable month to month than the other base cations, although on an annual basis it followed a similar pattern. No sustained increase in potassium flux at the experimental basin was observed as a result of the fertilizer application in October 1987. A few high potassium concentrations in summer 1988 and winter 1989 may be attributed to potassium inputs in fertilizer, but in general no effect was evident. Likewise, neither the flux nor stream concentration of nitrate seemed to increase in response to fertilizer application (fig. 20H).

Chloride differed from that of other solutes in that chloride flux was consistently higher at the experimental basin than at the control basin (fig. 20I). The disparity was greatest during water year 1987 . Because chloride is derived primarily from precipitation and takes limited part in biogeochemical reactions, the chloride flux in the two basins was expected to be similar. The consistently higher chloride flux in the experimental basin is not understood. Although minor differences resulted in flux, two separate episodes of unusually high chloride concentrations - nearly double the typical chloride maximum in fall-occurred in the experimental basin (fig. 18I). The high chloride concentrations occurred in October of 1985 and again in October of 1988. At those times only a slight increase in chloride concentration was observed in the control basin. The reason why chloride export exceeds chloride input by nearly a factor of 2 is unclear. One possibility is that road salt aerosols enter the basins as dry deposition, which was not measured in this study. Mineralogical sources of chloride are rare, and none are known in the Quabbin area (Rittmaster and Shanley, 1995).

The pattern of monthly sulfate flux (fig. 20G) was similar to that of the base cations; sulfate flux was usually greater in the control basin, except for water year 1987, when fluxes were nearly equal in each basin. The disproportionately greater flux in the control basin in water year 1989 was somewhat more pronounced for sulfate than for the other constituents. Other studies of clearcuts (for example, Nodvin and others, 1986) have documented decreased flux of sulfate because increased nitrification resulting from the cut promotes soil acidification, which increases the potential for sulfate adsorption. The changes in sulfate flux observed in water year 1989 are too subtle to invoke such an explanation-particularly in light of the apparent lack of effect on any of the other solutes. Moreover, the liming in water year 1989 would almost certainly negate any modest soil acidification that may have resulted from the cutting.

Alkalinity flux (fig. 20F) closely paralleled basecation flux; fluxes were nearly identical in each basin from June 1986 through September 1987. Similar to 
calcium flux, the alkalinity flux was greater in the control basin than in the experimental basin in water year 1989, an indication that none of the applied lime was transported to streamwater. The pattern of silica flux paralleled that of calcium and magnesium fluxes. Dissolved silica results primarily from mineral weathering; the similarity of these three patterns indicates that mineral weathering is a common source for silica, calcium, and magnesium.

\section{Changes in Sediment Transport}

Suspended-sediment concentration was determined for samples collected occasionally during the pre- and post-treatment periods at the outlets of the control and experimental basins and during the posttreatment period at the headwaters site in the experimental basin (fig. 21). Samples were collected on the same day at the outlets of the experimental and control basins. Suspended-sediment concentrations generally increased as stream discharge increased. Results from the 36 samples at each site indicate that rates of physical weathering are higher in the control basin than those in the experimental basin. Physical weathering rates in basins can differ because of differences in geology and soils. Higher background concentrations of suspended sediment in the control basin were attributed to higher basin relief in the control basin. Interpretation of suspended-sediment concentrations at high flow was tentative because sampling was limited; generally only 1-2 samples were collected per site during high-flow periods. Based on these limited data, the concentrations of suspended sediments in the experimental basin were higher than those in the control basin during high flow in April 1987, which was 6 months after the cutting began. However, suspended-sediment concentrations were higher in the control basin during storms in May 1988 and May 1989.

At the headwaters stream gage near the area of most of the forest clearing in the experimental basin, suspended-sediment concentration increased sharply during the clearing operations in late 1986 and early 1987 (fig. 21). Concentrations in two samples in April 1987 were 90 and $140 \mathrm{mg} / \mathrm{L}$, considerably higher than peak concentrations at the basin outlets. However, suspended-sediment concentrations for the following years at the headwater site were reduced to levels similar to those at the basin outlets. The conversion of the cleared area to grassland, which took place in the same year as the clearing, stabilized the disturbance and likely slowed erosion rates.

\section{Changes in Biogeochemical Controls on Water Quality}

The close similarity of the hydrology and streamwater chemistry of the two basins makes possible a common discussion of their biogeochemistry before basin disturbance. In general terms, the differences between solute inputs and outputs in the two basins (fig. 19) are typical of those found in undisturbed forested basins in the northeastern United States (Likens and others, 1977). Precipitation is acidic, characterized by a weak mixture of nitric and sulfuric acid with minor amounts of chloride and base cations. Hydrogen ion and nitrate are mostly retained in the basins. In contrast, their net export is small. Base cations (calcium, magnesium, sodium, potassium), silica, and alkalinity, which have minor or negligible inputs in precipitation, have a high net export primarily as a result of weathering. Chloride and sulfate have a net export that is intermediate between those of the constituents previously mentioned above. Sources of chloride and sulfate are thought to be minor in the basin, and each is relatively conservative; thus, outputs should reflect inputs. In the eastern United States, approximately half of sulfate inputs are in the form of dry deposition (Lindberg and Garten, 1988), which was not measured in this study. Thus, the combined input of sulfate (wet plus dry) probably exceeds outputs. This conclusion is consistent with the likelihood that some sulfate is retained in the basins through sulfate reduction in wetlands and (or) sulfate adsorption in basin soils. The excess chloride export is less easily explained, but one possibility as mentioned previously, is dry deposition of sodium chloride aerosol derived from locally applied road salt.

Chemistry of streamwater leaving the two basins reflects weathering of the silicate minerals in the local bedrock and till. Superimposed on the geochemical processes of weathering and ion exchange are biogeochemical processes such as nutrient cycling and sulfate reduction. The importance of the biological component is indicated in that most of the soluteconcentration models had seasonal components (table 6). Although discharge, as expected, generally was the most important parameter affecting solute concentrations, variation in concentration of several solutes also was attributable to seasonal factors. For example, in the post-treatment period in the experimental basin, the model for sulfate, which generally is very sensitive to changes in discharge, had no discharge term at all; variation in sulfate concentration was explained by a seasonal model alone $\left(r^{2}=0.63\right)$. 

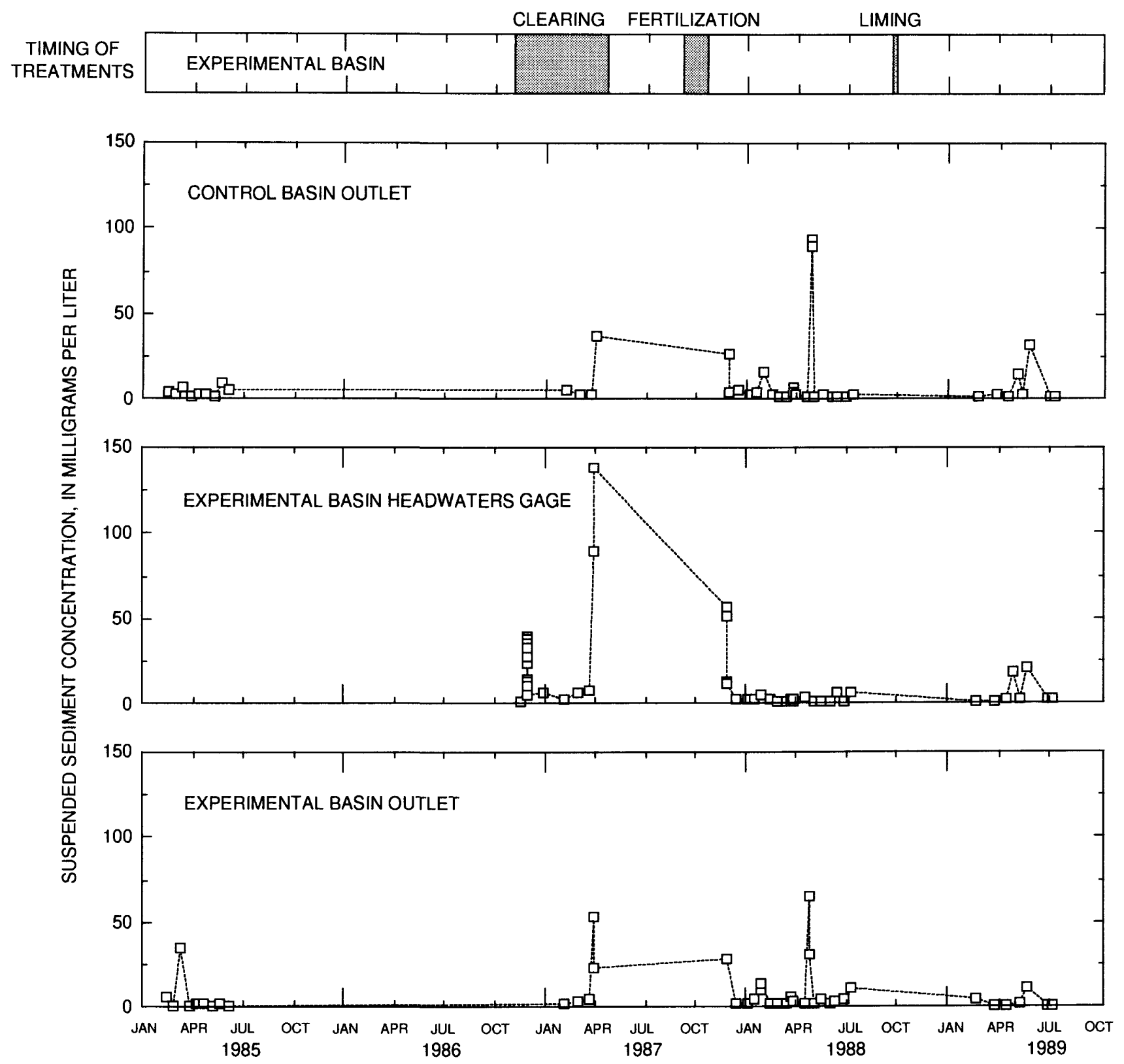

Figure 21. Timing of treatments and concentrations of suspended sediment at the control-basin outlet, experimental-basin headwaters gage, and experimental-basin outlet, Dickey Brook Basin, central Massachusetts, February 1985 through September 1989. 
For solutes that have seasonal controls, the seasonality is represented in the concentration model by a sine wave of period one year. The phase of the sine wave timing (that is, of the maximum and minimum) offers additional clues about the biogeochemical processes that affect solute concentrations, and the amplitude indicates the relative importance of the seasonal control. For example, a minimum sulfate concentration near July 12 was simulated with the post-treatment seasonal sulfate model, consistent with the time of maximum sulfate reduction which commonly peaks during the warmest time of the year. Sulfate adsorption is ruled out as an explanation of the seasonal behavior. Sulfate adsorption would be as strong during winter base flow as during summer base flow (Shanley and Peters, 1993); moreover, a model that accounts for sulfate adsorption also would need a flow component to explain increases in sulfate that typically occur during storm runoff, when water following shallow flow paths bypasses the mineral soils where adsorption takes place.

The behavior of the base cations calcium, magnesium, and sodium in the pre- and post-treatment periods in the experimental basin indicates that their concentrations are affected by a simple dilution mechanism. No seasonal component was utilized in model simulation of base cations, and concentration was inversely related to discharge. This model form indicates that these solutes are contributed primarily by weathering. Solute concentrations are higher during periods of base flow because the hydrograph during those periods is dominated by ground water, which, compared to storm runoff, has acquired more weathering products along its relatively longer flowpaths and during its greater contact time with mineral surfaces in the regolith. Storm runoff is low in base cations and causes dilution of base-flow cation concentrations. Thus, the concentration models for these solutes have flow components only; no seasonal biogeochemical processes are important enough to call for seasonal components to the models. In the control basin, concentration models for the base cations had seasonal components, but only of minor significance. For example, the model for sodium in the control basin had a seasonal component, but its amplitude was only $4 \mu \mathrm{eq} / \mathrm{L}$. Comparison of this amplitude to the model constant (analogous to the $y$-intercept in a simple regression) of $62 \mu \mathrm{eq} / \mathrm{L}$ indicates that the seasonal component is minor.

Alkalinity behaves similarly to base cations, consistent with their common source in mineral weathering. However, the relative increase in alkalinity in summer is greater than that of base-cation concentrations, indicative of an additional seasonal control. The seasonal control on alkalinity is reflected in the alkalinity concentration models for the control basin, the pre-treatment experimental basin, and the post-treatment experimental basin. All alkalinity models have seasonal components that peak in late spring or summer. The process responsible is most likely sulfate reduction, which increases alkalinity as sulfate decreases. The seasonal components for sulfate and alkalinity are approximately 6 months out of phase in all three models, lending support to this explanation.

Model structures for silica, chloride, and nitrate concentrations also have seasonal components indicative of biological interactions. Nitrate in the experimental basin is the most straightforward to interpret, having a peak in the seasonal sine wave in February and thus a minimum in August. This pattern is consistent with maximum biological uptake of nitrate in late summer, when nitrate concentrations in streamwater decrease to near zero. The amount of nitrate in streamwater at the experimental basin is only a minor fraction of the amount of nitrate entering the basin in precipitation; thus, biological uptake affects nitrate flux all year. An interesting aspect of the nitrate models is that using longer-term average flow (for the post-treatment period, 45 days) resulted in more accurate simulations of concentration than instantaneous flow, an indication of the importance of antecedent conditions to nitrate flux. During dry periods, nitrate concentrations build up in the soil because of nitrification-the conversion of organic nitrogen to inorganic nitrate. This nitrate is readily flushed to streamwater by storms. Nitrate concentration is inversely related to stream discharge. Thus, in generally wet periods (as indicated by high 45day discharge), little nitrate buildup occurs in the soil, and nitrate concentrations in streamwater are kept low. 
Silica and chloride have minimal interaction with the biota, so the strong seasonal components in the concentration models are unexpected. Silica may be incorporated in diatom blooms, consistent with its seasonal minimum in June or July. Chloride, which also is at a minimum at this time, may likewise be incorporated into biota. Despite the common assumption that chloride is conservative, Peters (1989) has presented evidence that it is taken up by trees.

Concentrations of potassium are controlled by several processes, both geochemical and biological, and potassium concentration is thus less predictable (Likens and others, 1977). This multiplicity of controls was reflected in lower $r^{2}$ values for the potassium models. A significant percentage of the variance in potassium concentration for the post-treatment period in the experimental basin could not be simulated in the models. In the control basin, the model has a seasonal component only. Peak potassium concentration from the model occurred at January 1, consistent with summer biological uptake of potassium. The experimental basin pretreatment model likewise had a seasonal peak for potassium in early winter and also had a discharge term with positive slope (increasing concentration with increasing flow). Positive concentration-discharge relations are not uncommon for potassium (Likens and others, 1977). A considerable amount of potassium is associated with organic matter in upper soil horizons. This source contributes potassium to streamwater, as storm runoff follows shallow flow paths and contacts these horizons and (or) ground water rises into these zones.

Hydrogen ion concentration had a minor seasonal component in two of the three models, but in general it was controlled by discharge. Hydrogen ion concentrations increased with increasing discharge, probably for the same reason as did potassium. Higher flows are associated with more runoff contact with surficial organic-soil horizons. Weak organic acids released by this contact may cause the observed increases in hydrogen ion. Alternatively, rapid movement of precipitation to the stream during high flow may result in less removal of atmospheric hydrogen ion by weathering or ion-exchange reactions. Increases in hydrogen ion at high flow must be interpreted in context; even at high flows, hydrogen ion concentrations in the streamwater were nearly two orders of magnitude lower than those in unbuffered precipitation. Thus, these patterns, and the postulated controls on hydrogen ion, are of minor significance in the overall context of processes affecting streamwater chemistry.

\section{Changes in Acid-Neutralization Processes}

Acid precipitation is effectively neutralized at the experimental basin. Atmospheric inputs of strong acids are converted through biogeochemical processes to calcium magnesium bicarbonate-type waters. A key to this process is the ability of the basins to retain some of the sulfate inputs, probably by sulfate reduction in wetland areas bordering the major stream channels. During periods of high runoff, however, the effectiveness of the sulfate-retention process diminishes, particularly during nonsummer periods when sulfate reduction is not as active. At these times, streamwater chemistry shifts to a calcium magnesium sulfate-type water, and alkalinity is reduced. Alkalinity less than $50 \mu \mathrm{eq} / \mathrm{L}$ was recorded five times in the experimental basin, before and after basin treatment, and two times in the control basin (fig. 18F). Thus, the experimental-basin system is not in danger of chronic acidification in the immediate future, but it approaches episodic acidification during high flows.

As with the effects on biogeochemical processes, the effect of the forest clearing, fertilization and liming on acid neutralization was negligible. Fluxes of alkalinity and sulfate were affected little by the basin treatment. The massive application of lime in the cleared area represents a major one-time addition to the acid-neutralizing capacity of the basin, equivalent to the amount of calcium that was exported from the experimental basin in the 3 water years, 1986, 1987, and 1988 (fig. 19B; table 5). Over time, associated increases in base cations and alkalinity probably would be detectable at the basin outlet. Two factors may prevent this signal from appearing at the basin outlet in the short term. First, the newly applied lime that dissolved and became available to plants would be sequestered by the highly productive rye and field grasses and the new forest regrowth. In other words, the calcium and carbonate inputs would be added to the terrestrial biogeochemical cycle rather than removed by way of streamflow. Much of the added calcium may be permanently incorporated in biomass. Over time, however, leakages from the biogeochemical cycle to surface waters could be expected to result in increased export of calcium and alkalinity from the basin. Second, the applied lime may not readily dissolve. In a recent study at Woods Lake in the Adirondack Mountains, N.Y., in which lime was applied to a large watershed by helicopter, undissolved lime pellets were found on the forest floor and on the streambed within pools in a small stream 1 year after application (Douglas Burns, U.S. Geological Survey, oral commun., 1991). 


\section{SUMMARY AND CONCLUSIONS}

The effects of selective forest clearing, fertilization, and liming were investigated at Dickey Brook Basin, which drains to Quabbin Reservoir in central Massachusetts. A paired-basin approach was used in the investigation. Background conditions were monitored in a control basin (Dickey Brook Tributary Basin) and in an experimental basin (Dickey Brook Basin) from February 1985 through September 1986. Although minor differences in bedrock geology are present (more gabbro in the control basin), hydrologic setting (15 percent wetlands in the experimental basin and 4 percent in the control basin), and average slope (5 percent in control basin and 2 percent in experimental basin), the chemistry and hydrology of the two basins were similar. The experimental basin was subject to higher evapotranspiration rates because of its much higher percentage of wetlands. Consequently, before forest clearing, the control basin produced higher sustained base flows and slightly higher total water yield. Solute concentrations were slightly higher in the control basin, probably because it is underlain by a higher percentage of the more easily weathered gabbro. In both basins, acidic deposition was neutralized by retention of most of the hydrogen and nitrate and probably some sulfate (allowing for the sulfate inputs from dry deposition, which was not measured). Streamwater quality shifted from a calcium magnesium bicarbonate type-water at base flow to a calcium magnesium sulfate type water at higher flows.

The experimental basin was selectively cleared from October 1986 through April 1987. The clearing resulted in a slight increase in water yield and solutes in water year 1987, most of which occurred during the spring high-flow period. The increased flow probably resulted from increased insolation on the snow pack where the canopy had been moved, and thus more rapid snowmelt runoff from the cleared area, as well as from decreased evapotranspiration during the 1987 growing season. A decrease in evapotranspiration in water year 1987 was indicated by higher ground-water levels in two wells within the cut area. For water year 1987, the summer decline of the water table at these wells was the least of all five summers in the study period, whereas the summer decline at wells in the control basin was the maximum of all five summers. Fluxes of nearly all major solutes increased in the experimental basin during water year 1987. Increased fluxes were attributed primarily to increased water yield rather than to a major perturbation in biogeochemical cycles.
Further effects of the forest clearing after the summer of 1987 were inconsequential. New surface vegetation stabilized the cut areas. Furthermore, little or no effect was observed from the fertilization and liming applications in following years, despite the high loading of nitrate, potassium, and calcium from the treatments relative to inputs in precipitation. Much of the added nitrogen, potassium, and calcium probably was incorporated in nutrient cycles and (or) the transport of these solutes was limited by slow ground-water flow such that the signal had not reached the basin outlet before the study ended in September 1989. The minimal effect observed from the forest clearing and treatment was probably a consequence of the limited area of the tree cutting, and the position of the cleared area in the headwaters of the basin.

\section{REFERENCES CITED}

Aubertin, G.M., and Patric, J.H., 1974, Water quality after clearcutting a small watershed in West Virginia: Journal of Environmental Quality, v. 3, no. 3, p. 243-249.

Bent, G.C., 1994, Effects of timber cutting on runoff to Quabbin Reservoir, central Massachusetts, in Effects of human-induced changes on hydrologic systems: American Water Resources Association, 1994 Annual Summer Symposium, p. 187-196.

Bigelow, D.S., 1982, National Atmospheric Deposition Program instruction manual, site operation: Fort Collins, Colo., Colorado State University, National Atmospheric Deposition Program, Program Coordinator's Office, $30 \mathrm{p}$.

Bormann, F.H., and Likens, G.E., 1979, Pattern and process in a forest ecosystem-disturbance, development, and the steady state based on the Hubbard Brook ecosystem study: New York, Springer-Verlag, 253 p.

Corbett, E.S., Lynch, J.A., and Sopper, W.E., 1978, Timber harvesting practices and water quality in the eastern United States: Journal of Forestry, v. 76, p. 484-488.

Davis, S.N., and De Wiest, R.J.M., 1966, Hydrogeology: New York, John Wiley, 463 p.

Dunne, Thomas, Moore, T.R., and Taylor, C.H., 1975, Recognition and prediction of runoff-producing zones in humid regions: Hydrologic Sciences Bulletin, v. 20, p. 305-327.

Dunne, Thomas, and Leopold, L.B., 1978, Water in environmental planning: San Francisco, W.H. Freeman and Company, p. 126-162. 
Fishman, M.J., and Friedman, L.C., 1989, Methods for determination of inorganic substances in water and fluvial sediments: U.S. Geological Survey Techniques of Water-Resources Investigations, book 5, chap. A1, $545 \mathrm{p}$.

Gallant, J., Link, T.E., Pardo, A., Kendall, T., and Reid, J.B., 1990, Bedrock controls on acid neutralization in Quabbin Reservoir tributaries, Massachusetts [abs.]: Geological Society of America, 25th annual meeting, Syracuse, N.Y., March 4-7, 1990, v. 22, p. 19.

Godfrey, P.J.,1988, Acid rain in Massachusetts - the Massachusetts acid rain research program in action: Amherst, Mass., University of Massachusetts, Water Resources Research Center, $54 \mathrm{p}$.

Gorham, E., Martion, F.B., and Litzau, J.T., 1984, Acid rain-ionic correlations in the eastern United States, 1980-1981: Science, v. 225, p. 407-409.

Harr, R.D., 1986, Effects of clearcutting on rain-on-snow runoff in western Oregon - a new look at old studies: Water Resources Research, v. 22, no. 7, p. 1095-1100.

Helsel, D.R. and Hirsch, R.M., 1992, Statistical methods in water resources: Amsterdam, Elsevier, 522 p.

Hornbeck, J.W., Pierce, R.S., Likens, G.E., and Martin, C.W., 1985, Moderating the impact of contemporary forest cutting on hydrologic and nutrient cycles: International Association of Hydrologic Sciences Publication 117, p. 423-433.

Hornbeck, J.W., Martin, C.W., Pierce, R.S., Bormann, F.H., Likens, G.E., and Eaton, J.S., 1986, The northern hardwood forest ecosystem - ten years of recovery from clearcutting: Broomall, Pa., U.S. Forest Service, Northeastern Forest Experiment Station, Research Paper NE-596, 30 p.

Hornbeck, J.W., Adams, M.B., Corbett, E.S., Verry, E.S., and Lynch, J.A., 1993, Long-term impacts of forest treatments on water yield - a summary for northeastern USA: Journal of Hydrology, v. 150, p. 323-344.
Huntington, T.G., Hooper, R.P., and Aulenbach, B.T., 1994, Hydrologic processes controlling sulfate mobility in a small forested watershed: Water Resources Research, v. 30 , no. 2 , p. $283-295$.

Lawrence, G.B., Fuller, R.D., and Driscoll, C.T., 1987, Release of aluminum following whole-tree harvesting at the Hubbard Brook Experimental Forest, New Hampshire: Journal of Environmental Quality, v. 16, p. 383-390.

Likens, G.E., Bormann, F.H., Pierce, R.S., Eaton, J.S., and Johnson, N.M., 1977, Biogeochemistry of a forested ecosystem: New York, Springer-Verlag, 146 p.

Likens, G.E., Bormann, F.H., Johnson, N.M., Fischer, D.W., and Pierce, R.S., 1970, Effects of forest cutting and herbicide treatment on nutrient budgets in the Hubbard Brook watershed-ecosystem: Ecological Monographs, v. 40 , p. 23-47.

Lindberg, S.E., and Garten, C.T, 1988, Sources of sulphur in forest canopy throughfall: Nature, v. 336, p. 148-151.

Makower, J., 1964, Geology of the Prescott intrusive complex, Quabbin Reservoir quadrangle, Massachusetts: Amherst, University of Massachusetts, M.S. thesis, $91 \mathrm{p}$.

Martin, C.W., and Harr, R.D., 1989, Logging of mature Douglas-fir in western Oregon has little effect on nutrient output budgets: Canadian Journal of Forest Research, v. 19, p. $35-43$.

Martin, C.W., and Pierce, R.S., 1980, Clearcutting patterns affect nitrate and calcium in streams of New Hampshire: Journal of Forestry, v. 78, no. 5, p. 268-272.

Martin, C.W., Noel, D.S., and Federer, C.A., 1984, Effects of forest clearcutting in New England on stream chemistry: Journal of Environmental Quality, v. 13, p. 204-210.

Mrazik, B.R., Mader, D.L., and MacConnell, W.P., 1980, Integrated watershed management-an alternative for the Northeast: Massachusetts Agricultural Experiment Station, Amherst, Mass., Research Bulletin 664, 50 p. 
National Oceanographic and Atmospheric Administration, 1985, Climatological data, annual summary, New England: v. 97, no. 13, 36 p.

Nodvin, S.C., Driscoll, C.T., and Likens, G.E., 1986. The effect of $\mathrm{pH}$ on sulfate adsorption by a forest soil: Soil Science, v. 142, p. 69-75.

Patric, J.H., and Reinhart, K.G, 1971, Hydrologic effects of deforesting two mountain watersheds in West Virginia: Water Resources Research, v. 7, p. 1182-1188.

Peters, N. E., 1989, Chloride cycling in forested lake watersheds in the west-central Adirondack Mountains, New York, in Moldan, Bedrich, and Paces, Tomas, eds., GEOMON, International workshop on geochemistry and monitoring in representative basins-extended abstracts: Prague, Czechoslovakia, Geological Survey, p. 264-266.

Pierce, R.S., Hornbeck, J.W., Likens, G.E., and Bormann, F.H., 1972, Nutrient loss from clearcuttings in New Hampshire, in Csallany, C.S. and others, eds., Sympo-. sium on Watersheds in Transition, Fort Collins, Colorado, June 19-22, 1972: Urbana, Ill., American Water Resources Association, p. 285-295.

Rantz, S.E., and others, 1982, Measurement and computation of streamflow, volume 1 -measurement of stage and discharge: U.S. GeologicaI Survey Water-Supply Paper $2175,284 \mathrm{p}$.

Rittmaster, R.L., and Shanley, J.B., 1995, Factors affecting water quality and net flux of solutes in two stream basins in the Quabbin Reservoir Watershed, central Massachusetts, 1983-1985: U.S. Geological Survey WaterResources Investigations Report 94-4003.

Rutter, A.J., 1968, Water consumption in forests, in Kozlowski, T.T., ed., Water deficits and plant growth: New York, Academic Press, v. 2, p. 23-84.

Shanley, J.B., 1994, Effects of ion exchange on stream solute fluxes in a basin receiving deicing salts: Journal of Environmental Quality, v. 23, p. 977-986.

Shanley, J.B., and Peters, N.E., 1993, Variations in aqueous sulfate concentrations at Panola Mountain, Georgia: Journal of Hydrology, v. 146, p. 361-382.
Stekl, P.J., 1985, A hydrologic investigation of two small watersheds of the eastern Quabbin subbasin: Amherst, University of Massachusetts, M.S. thesis, $169 \mathrm{p}$.

Thornthwaite, C.W., and Mather, J.R., 1955, The water balance: Centerton, N.J., Laboratory of Climatology, Publications in Climatology, v. 8, no. 1, 104 p.

Troendle, C.A., 1983, The potential for water yield augmentation from forest management in the Rocky Mountain region: Water Resources Bulletin, v. 19, p. 359-373.

Troendle, C.A., and King, R.M., 1985, The effects of timber harvest on the Fool Creek watershed, 30 years later: Water Resources Research, v. 21, p. 1915-1922.

Trimble, S.W., Weirich, F.H., and Hoag, B.L., 1987, Reforestation and the reduction of water yield on the southern Piedmont since circa 1940: Water Resources Research, v. 23, p. $425-437$.

Verry, E.S., 1986, Forest harvesting and water-the Lake States experience: Water Resources Bulletin, v. 22, p. 1039-1047.

Vitousek, P.M., 1981, Clear-cutting and the nitrogen cycle: Ecological Bulletin, v. 33, p. 631-642.

Wandle, W.W., Jr., 1983, Estimating peak discharges of small, rural streams in Massachusetts: U.S. Geological Survey Water-Supply Paper 2214, 26 p.

Wolock, D.M., Hornberger, G.M., and Musgrove, T.J., 1990, Topographic effects on flow path and surface water chemistry of the Llyn Brianne catchments in Wales: Journal of Hydrology, v. 115, p. 243-259.

Yuretich, Richard; Leonard, Wendy; and Pohanka, Susan, 1989, Hydrogeologic factors affecting acid neutralization in Cadwell Creek watershed, west central Massachusetts: Water Resources Research, v. 25, p. 644-654.

Zen, E-an, Goldsmith, G.R., Ratcliffe, N.L., Robinson, P., and Stanley, R.S., 1983, Bedrock geologic map of Massachusetts: Washington, D.C., U.S. Geological Survey, 3 sheets. 